\author{
UNIVERSIDADE DE SÃO PAULO \\ Instituto de Física \\ Instituto de Química \\ Faculdade de Educação
}

\title{
A VISÃO DE CURRÍCULO NOS LIVROS DIDÁTICOS: O ELETROMAGNETISMO NO ENSINO MÉDIO COMO EXEMPLO
}

\author{
Giuliano Salcas Olguin
}

Orientador: Prof. Dr. Luis Carlos de Menezes

Dissertação Mestrado apresentada ao Programa de Pós-Graduação em Ensino de Ciências - Modalidade Física, do Instituto de Física, Instituto de Química e Faculdade de Educação da Universidade de São Paulo para obtenção do Título de Mestre em Ensino de Ciências.

Banca Examinadora

Prof. Dr. Luis Carlos de Menezes - IFUSP

Prof. Dr. João Zanetic - IFUSP

Prof. Dr. Fernando José de Almeida - PUCSP 
À minha mãe, à minha namorada e aos meus amigos pela dedicação, paciência e apoio. 


\section{Resumo}

No presente trabalho é desenvolvida uma análise do currículo que se pode inferir de três conjuntos de livros didáticos para o Ensino Médio, com especial atenção ao desenvolvimento dos conceitos de eletromagnetismo. A teoria de currículo de Michael APPLE foi tomada como principal recurso para essa análise.

Inicialmente, é apresentado o desenvolvimento dos conceitos de currículo dominantes em diferentes períodos, considerando-se autores como TYLER, EISNER e chegando-se à teoria de currículo de Michael APPLE, que aborda a relação entre o currículo e fatores sociais como política, economia e cultura. Esses fatores externos são considerados ao se analisar diferentes temas relacionados aos currículos, como a legitimação do conhecimento através do livro didático, as influências da implementação de um currículo nacional ou de uma avaliação nacional, as características internas de uma escola, a reprodução do conhecimento e o comércio do livro didático.

Depois de definir o referencial teórico faz-se breve histórico do currículo em livros didáticos de física no Brasil, entre eles os textos associados a projetos como o PSSC, FAI, PEF, PBEF e GREF. Essa abordagem leva em consideração a teoria de APPLE; ou seja, essa evolução é relacionada a fatores políticos, sociais e culturais de nosso país.

Analisam-se então os Parâmetros Curriculares Nacionais, o Exame Nacional do Ensino Médio e os exames vestibulares que são fatores específicos que hoje condicionam o Ensino Médio no Brasil.

Por fim, faz-se uma análise do ensino dos conceitos de eletromagnetismo em três livros didáticos contemporâneos para o Ensino Médio como exemplo do uso do referencial teórico desenvolvido e da análise dos fatores condicionantes em nosso país. 


\section{Abstract}

On this work we developed an curriculum analysis on three sets of didatic books fo rhigh school teaching, with special attention to the development of electromagnetism concepts. Michael APPLE's curriculum theory was taken as the main guideline for this analysis.

Initially, the development of the concepts of curriculum are presented, considering authors such as TYLER, EISNER and finally APPLE that studies the relation between curriculum and social factors such as politics, economy and culture. Those external factors are considered while analyzing different subjects related to the curriculum, as the legitimation of the knowledge through the didactic book, the influences of the implementation of a national curriculum or evaluation, the internal characteristics of a school, the reproduction of knowledge and the commerce of didactic books.

After defining the theoretical reference, we carried out a brief survey on the historical development of the curriculum and didactic books of physics in Brazil, dealing with texts related to projects such as PSSC, FAI, PEF, PBEF and GREF. This approach also takes into consideration the theory of APPLE; meaning that this discussion is related to political, social and cultural elements of our country.

An analysis is then conducted on the National Curricular Parameters (Parâmetros Curriculares Nacionais), on the Nacional High School Examination (Exame Nacional do Ensino Médio) and on the university entrance examinations (exames vestibulares) which are the main factors that determine the high school teaching in Brazil.

Finally, an analysis is made on three contemporary didactic books for high school, with special attention to the development of electromagnetism concepts, that exemplify the use of the developed theoretical referential and of the analysis of the condition factors in our country. 
1. Antecedentes

2. Introdução. 13

3. Teorias do Currículo: de TYLER a EISNER ......................................................... 16

4. O Conceito de Currículo de APPLE......................................................................... 22

5. O Currículo e o Livro Didático............................................................................. 41

5.1 Conhecimento Legítimo e o Livro Didático....................................... 42

5.2 Um Currículo Nacional e uma Avaliação Nacional............................. 51

5.3 A Escola Reprodutora e o Livro Didático............................................ 59

5.4 Cultura e Comércio do Livro Didático................................................. 67

6. A Evolução do Currículo e dos Livros Didáticos no Brasil.................................. 74

7. O Cenário Contemporâneo do Ensino Médio no Brasil........................................ 87

8. Os Livros Didáticos, a Educação Contemporânea e a Teoria de Currículo de

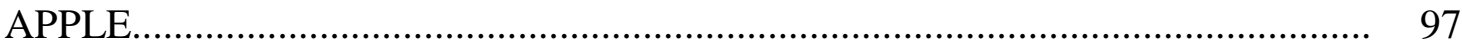

9. Metodologia para Análise dos Livros Didáticos Contemporâneos........................ 99

10 Análise dos Livros

10.1 Análise do Livro "Curso de Física", vol. 3 (autores: Antônio Máximo e Beatriz Alvarenga)............................................................ 103

10.2 Análise das apostilas "Leituras de Física: Eletromagnetismo" (elaborado pelo GREF - Grupo de Reelaboração do Ensino de Física)... 123

10.3 Análise do Livro "Os Fundamentos da Física”, vol. 3 (autores:

Francisco Ramalho Junior, Nicolau Gilberto Ferraro e Paulo Antônio de Toledo Soares) (................................................................................... 144

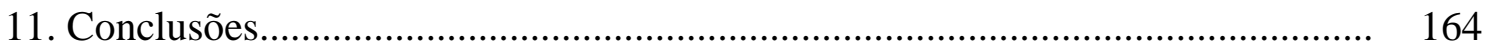

12. Conjecturas sobre o futuro dos recursos didáticos....................................... 169

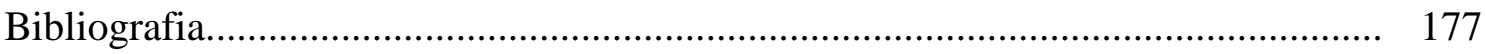




\section{Antecedentes}

Após tantos anos lidando e trabalhando com educação percebo o trajeto de idas e vindas que resulta na mistura complexa de elementos que me conduzem ao aprendizado que hoje realizo. É difícil reunir todas as passagens desse trajeto, mas há algumas das quais tenho clareza. A educação sempre foi uma das questões mais vivas dentro de mim; mesmo tendo passado por cursos de arte, design e comunicação e por trabalhos em pesquisa científica com aceleradores de partículas, minha verdadeira motivação sempre esteve nas questões da educação. Isso me impulsionou a fazer o mestrado em Ensino de Física na Universidade de São Paulo, que me permitiu estudar mais, estar em contato com pessoas que refletem sobre o mesmo tema e atuar em projetos dentro da Universidade.

No início dessa Pós-graduação pensei em escrever algo que envolvesse mais diretamente meus aprendizados passados. Pensei em uma dissertação sobre Ciência, Arte e Educação. Procurei autores, referências, mas me faltou um foco satisfatório, talvez devido à amplitude do assunto. Ainda sem definir claramente minha nova investigação, fui cursando disciplinas, conversando com colegas e realizando algumas atividades acadêmicas.

No primeiro semestre, eu cursei três disciplinas: "Os Fundamentos da Física e a Física Contemporânea como Conteúdos Instrucionais" ", com o professor Luis Carlos de Menezes, "Construção e Realidade no Ensino de Física"2, com os professores Manoel Roberto Robilotta e Mauricio Pietrocola Pinto de Oliveira e "Preparação Pedagógica do Ensino" (PAE) ${ }^{3}$, com o professor Celso Luiz Lima. Nessas disciplinas eu tive a

\footnotetext{
${ }^{1}$ Disciplina ECF5709 - Os Fundamentos da Física e a Física Contemporânea como Conteúdos Instrucionais

Objetivos: Propiciar uma apreciação de conjunto dos fundamentos clássicos e dos desenvolvimentos recentes da física, para subsidiar uma avaliação crítica e uma possível reconceituação dos conteúdos instrucionais oferecidos nas disciplinas de física nos diferentes cursos superiores e médios, tanto no que se refere aos conceitos fundamentais da física clássica quanto aos desenvolvimentos da física contemporânea, tomados como elementos de visões de mundo e como instrumental teórico para outras ciências e para a tecnologia. - Texto retirado do Fenix Web -

${ }^{2}$ Disciplina ECF5784 - Construção e Realidade no Ensino de Física

Objetivos: Promover uma reflexão, de caráter epistemológico, acerca da natureza da atividade científica, com especial atenção à física. - Texto retirado do Fenix Web -

${ }^{3}$ Disciplina FMT5869 - Preparação Pedagógica de Ensino

Objetivos: Aulas e seminários proferidos por especialistas nas áreas de Ensino de Física, Pedagogia e Psicologia Educacional no sentido de aprimoramento do estudante de pós-graduação para o exercício de atividades didáticas. - Texto retirado do Fenix Web -
} 
oportunidade de refletir sobre questões que não foram abordadas em profundidade na graduação.

O professor Menezes apresentou uma visão geral da física combinando abordagens históricas, aspectos filosóficos e a relação da física com a tecnologia contemporânea. O formato das aulas também foi um aprendizado, pois a participação ativa dos alunos nas discussões e nas apresentações dos conteúdos me levou a repensar o conceito de aprender e de ensinar.

Já na disciplina ministrada pelos professores Robilotta e Pietrocola, eu pude perceber como a minha visão do que é ciência estava limitada. As discussões e textos me orientaram a um pensar diferente da física. O caráter epistemológico da atividade científica e a visão de ciência de diferentes pensadores, de Bacon até Thomas Kuhn foi um assunto muito instigante.

O primeiro semestre de Pós-Graduação foi, assim, um susto e um grande prazer. As disciplinas derrubaram alguns pré-conceitos pessoais e eu pude começar a pensar sobre o que é educação. As conversas com os colegas de turma também foram muito importantes e me ajudaram nessa travessia. Montamos grupos de estudos, começamos a discutir textos de educação que não estavam relacionados com as disciplinas e, no fim, nos tornamos grandes amigos.

Um autor em particular me chamou atenção, seu nome Paulo FREIRE. Em um grupo pequeno, eu e alguns colegas da Pós começamos a ler e discutir os textos de FREIRE. Isso despertou em mim um novo pensar sobre o que é a educação. Com um misto de insegurança com vontade de mudar, eu comecei a me aprofundar no assunto e notei que faltava na minha formação um pensar que relacionava a educação com questões políticas, sociais e econômicas.

Mas não era só isso. Lembro com saudades quando o grupo ia tomar café na lanchonete da física. Discutíamos coisas pessoais, problemas no trabalho e dificuldades no mestrado. Também aprendi muito nessas conversas. Muitos colegas já tinham muita experiência de sala de aula e de pesquisa e nas conversas eu ouvia atento os diálogos e a troca de informações entre eles.

Pensei então em fazer um segundo semestre com menos disciplinas, me focando assim mais na proposta de dissertação de mestrado. Nesse sentido, eu fiz apenas uma disciplina, "Fundamentos da Mecânica Quântica"4, com o professor Osvaldo Frota

\footnotetext{
${ }^{4}$ Disciplina ECF5842 - Fundamentos da Mecânica Quântica
} 
Pessoa Junior. Com uma ótima didática, a abordagem da física através de pensamentos filosóficos e não determinísticos permitiu uma nova visão da física.

Nesse meu primeiro ano eu também fui monitor das disciplinas de "Eletricidade II" e "Eletromagnetismo" para Licenciatura em Física, com a professora Vera Bohomoletz Henriques. Foi um enorme aprendizado trabalhar com alunos de Licenciatura e ao mesmo tempo rever, pela ótica do professor, o eletromagnetismo. As discussões que tive fora de sala de aula com a Vera Henriques foram muito interessantes e geraram em mim mais novas questões sobre educação. Dessas conversas e dessas reflexões, saiu a intenção de pesquisar os livros didáticos de eletromagnetismo, pois durante a monitoria, conversei com freqüência com a professora e com os alunos sobre os prós e contras de cada livro.

Verifiquei que as disciplinas estavam usualmente atreladas aos livros didáticos como material de estudo dos alunos ou como guia do professor. Minha prática também não foi muito diferente. Indiquei livros para leitura aos alunos de acordo com cada situação, mas os parâmetros que guiavam a minha escolha, nem sempre eram nítidos. Ao refletir sobre isso, percebi que deveria ter uma análise mais crítica dos livros didáticos para poder orientar melhor meus alunos, mas para isso eu precisava de critérios mais claros.

Assim, comecei a procurar formas de analisar os livros didáticos. Procurei teses, dissertações, artigos e verifiquei que uma forma interessante de analisar os livros é através do currículo que se infere de seus conteúdos e de sua abordagem. Estava claro para mim que o autor de um livro ao selecionar conteúdo, forma de abordagem e ordenação desse conteúdo, está propondo ou pressupondo uma determinada visão de currículo, que pode ou não ser endossada pelo professor.

Sendo assim, comecei a investigar as diferentes concepções de currículos. Estudei TYLER, EISNER, KLIEBARD, MCNEIL e GRUNDY, entre outros. Achei muito interessante a concepção de currículo de GRUNDY devido a abordagem baseada na teoria dos interesses cognitivos de HABERMAS. Aprofundei meus estudos em GRUNDY e fiquei fascinado com a sua teoria de currículo, principalmente com o currículo como práxis, onde o objetivo é a emancipação do ser humano, é a ação

Objetivos: O objetivo do curso é familiarizar o aluno com os problemas conceituais, filosóficos e de interpretação da Física Quântica, desenvolver sua intuição para que ele saiba prever o resultado de experimentos de pensamento, e reforçar seu manuseio do formalismo de medições, introduzindo-o aos operadores de densidade. - Texto retirado do Fenix Web - 
conjunta entre participantes ativos que visam à construção do conhecimento. Essa idéia vai contra a educação tradicional e exalta a auto-reflexão e a participação real dos alunos, elementos que acredito serem fundamentais para formação do aluno.

Essas indagações ficaram presentes em mim e eu as mantive no início do meu segundo ano. No terceiro semestre eu pensei em me aprofundar nas questões da educação. Fui então fazer duas disciplinas na Faculdade de Educação e uma na Física, que tratava de livros didáticos, respectivamente: "Metodologia do Ensino Superior", com a professora Myriam Krasilchik, "O Conhecimento em Sala de Aula: a Organização do Ensino", , com o professor Manoel Oriosvaldo de Moura e "A cidadania na Voz dos Manuais Escolares", Maria Eduarda do Nascimento Vaz Moniz dos Santos.

A Myriam Krasilchik propiciou um panorama de como se situa hoje a graduação no país, em que a relação entre educação, sociedade, política e economia foi na direção das reflexões que eu tinha. Já a divisão do currículo em oculto e explícito, apresentada nas aulas do Oriosvaldo, me fez pensar na difícil responsabilidade que cada professor tem, ao verificar todas as variáveis para que o estudante tenha um bom aprendizado.

As professoras Jesuína Lopes de Almeida Pacca e Maria Eduarda do Nascimento Vaz Moniz dos Santos abordaram diretamente o livro didático com o conceito CTS Ciência, Tecnologia e Sociedade. Essa observação trouxe atores interessantes que se relacionavam com o que eu queria pesquisar e me serviu para verificar uma nova perspectiva de estudo dos livros didáticos. Além disso, Maria Eduarda do Nascimento Vaz Moniz dos Santos mostrou exemplos de como os livros didáticos vêm se desenvolvendo na Europa.

Em paralelo às atividades disciplinares e de pesquisa, eu desenvolvi em meu segundo ano de Pós-Graduação o projeto "A Formação de Professores e a Pesquisa Cientifica", sob a Coordenação do Professor Menezes. Em conjunto com mais alguns

\footnotetext{
${ }^{5}$ Disciplina EDM5791 - Metodologia do Ensino Superior

Objetivos: Analisar informações e pesquisas sobre metodologia do ensino superior. Analisar diversos tipos de organização curricular no ensino de terceiro grau, considerando os princípios educacionais que refletem e suas implicações para a prática. Analisar processos de avaliação de ensino e suas relações com elementos do trabalho acadêmico - Texto retirado do Fenix Web -

${ }^{6}$ Disciplina EDM5730 - O Conhecimento em Sala de Aula: a Organização do Ensino

Objetivos: Analisar as implicações pedagógicas resultantes das pesquisas em ensino na organização de atividades educativas. - Texto retirado do Fenix Web -

${ }^{7}$ Disciplina ECF5741 - A cidadania na voz dos manuais escolares

Objetivos: Estudar os conceitos de Ciência, Tecnologia e Sociedade bem como implicações recíprocas, no conteúdo dos manuais escolares e construir um instrumento para a seleção de manuais. - Texto retirado do Fenix Web -
} 
alunos da graduação, fizemos dois documentários sobre grupos de pesquisa do Instituto de Física ${ }^{8}$. Esse projeto foi realizado no PROFIS - Espaço de Apoio, Pesquisa e Cooperação de Professores de Física - que é um novo espaço de investigação científico-pedagógica que promove projetos educacionais que envolvem alunos de licenciatura e bacharelado como protagonistas e professores do Ensino Médio e docentes universitários como assessores e coadjuvantes.

O objetivo do projeto era divulgar a pesquisa desenvolvida no Instituto de Física da USP para os alunos da Licenciatura e do Bacharelado. Em particular, para os alunos da Licenciatura, o vídeo traz informações que podem ser ensinadas no Ensino Médio, pois trazem uma abordagem simples dos conceitos físicos, enquanto que para os estudantes do Bacharelado, o vídeo transmite as possibilidades de pesquisa, e em especial de iniciação cientifica, que o Instituto oferece. Com essa atividade eu aprendi muito como desenvolver um projeto, liderar um grupo, fazer planejamento, aprender e ensinar meios multimídia. Enfim, todas as minhas atitudes de educador foram colocadas à prova nesse projeto. Foi um trabalho muito difícil de fazer, mas rendeu um resultado muito bom e o aprendizado foi inesquecível.

Por ironia do destino, voltei nesses projetos a trabalhar com o aspecto de arte e ciência, que pensei ter deixado de lado ao mudar de proposta de dissertação. No projeto, apliquei todo meu conhecimento, e da comunicação e arte pude, na prática, colocar as mãos nesse tema. Possivelmente esse tema vai me acompanhar a vida inteira, seja em textos acadêmicos, seja em algum projeto. Mas além dessa relação entre arte e ciência, também estava presente nessa atividade uma nova forma de aprender e de ensinar. $\mathrm{O}$ trabalho na equipe estava muito próximo de uma aula, mas o aprendizado não se dava de outra forma. Não existiam provas, não existia um cronograma pré-elaborado e não existia um professor que sabia tudo. Pelo contrário, tínhamos um objetivo que dependia da participação de todos, montávamos e remontávamos o cronograma a cada reunião semanal e aprendíamos uns com os outros, o que era até uma necessidade, já que a quantidade de coisas a serem aprendidas era muito grande (Cada um ficava responsável pelo aprendizado de um determinado assunto. Depois, esse conhecimento era compartilhado com os demais colegas). Logo, o que poderia ser uma digressão, um

\footnotetext{
${ }^{8}$ No primeiro semestre foi desenvolvido um vídeo apresentando o Laboratório de Materiais e Feixes LAMFI, coordenado pelo Prof. Dr. Manfredo H. Tabacnicks. No segundo semestre, foi elaborado um vídeo apresentando o GRHAFITE - Grupo de Estudos de Hádrons e Física Teórica, coordenado pelo Prof. Manoel Roberto Robilotta.
} 
desvio de rota, acabou sendo uma sinalização concreta para uma nova percepção do que pode ser currículo.

Além de desenvolver esse projeto e cursar as disciplinas, no meu segundo ano, em minha pesquisa, encontrei um autor, uma referência, que ia ao encontro das minhas inquietações. Depois, ao conversar com meu orientador, conheci Michael APPLE e os fatores políticos e culturais no currículo. Ao não levar em conta esses fatores, senti que minha análise estava ingênua e fora do contexto real de nossa sociedade. Nesse momento, um vazio começou a se configurar dentro de mim pedindo respostas. Várias questões e angústias que foram antes vividas na minha ação docente começaram a tomar forma e identidade. Muitas coisas ficaram mais claras e comecei a encarar a educação crítica como uma forma de combate, de resistência e reflexão crítica de nossa sociedade. A imagem do curso de Licenciatura que tinha cursado se mostrou frágil, ao não levantar essas questões e mostrar as influências externas na educação. Fiquei um pouco decepcionado e ao mesmo tempo instigado a me aprofundar nessa nova compreensão.

O resultado de todas atividades da Pós-Graduação, que compreendem as disciplinas, atividades extra-curriculares, discussões com colegas da pós, pesquisa e redação da dissertação, tem configurado um grande processo de ensino para mim. Com certeza, as minhas ações e idéias como educador já mudaram muito desde o início do mestrado. E, ao que parece, essa mudança não vai parar nunca, pois hoje vejo a educação quase como um ser vivo, com vida própria, que sempre se transforma e interage com outros aspectos de nossa sociedade, que por sua vez também sofrem transformações. Esse dinamismo altera minha percepção sobre o que é aprender e o que é ensinar a cada instante. No fim, ser educador se tornou uma profissão mais saborosa do que antes, do simplesmente ensinar para o aprender a ensinar e especialmente para o ensinar a aprender. A cada dia que passo sinto que estou na direção certa, que minhas decisões estão me levando à felicidade de aprender e à felicidade de ensinar.

Esse presente trabalho é então o resultado dessas investigações e anseios. Apresento o que aprendi com as idéias de APPLE, depois faço uma história de alguns livros didáticos desenvolvidos no Brasil e finalmente analiso alguns livros contemporâneos de física, em particular daqueles que tratam do Eletromagnetismo do Ensino Médio.

A seguir, é apresentada uma introdução que inicia a discussão sobre a relação entre currículo e livros didáticos. No intuito de mostrar como esse tema é desenvolvido 
nesse trabalho, também são descritos brevemente na introdução os capítulos dessa dissertação. 


\section{Introdução}

Pelo menos até o presente e por mais algum tempo, um instrumento didático utilizado pela grande maioria dos professores, em todos os níveis de ensino, é o livro didático. Desde os primeiros anos de escola, o estudante tem contato com livros, que propõem atividades, como pintar, desenhar, leitura de histórias simples pela professora, brincadeiras individuais e em grupos, manipulação de massa de modelar, observação de fatos que acontecem na escola e em casa, entre outros. Com o passar do tempo o aluno aprende a ler e escrever e, a partir desse momento, poderia ter uma interação maior com os livros. As possibilidades são muitas, pois em princípio o estudante poderia ir atrás de qualquer livro de forma independente e autônoma.

Porém, essa liberdade de escolha que existe fora de sala de aula, na escola é irreal, em geral, pois o aluno tem que seguir um livro didático pré-selecionado. Esse livro, que serve como guia, tanto para o aluno quanto para o professor, vai ser parte integrante do cotidiano escolar do estudante. Ou seja, como constituinte do processo educativo, o livro também conduz o aprendizado do aluno, pois apresenta uma proposta de ensino. E, tal proposta possui objetivos, metas, um conteúdo a ser abordado e uma forma de trabalhar esse conteúdo. Nessa medida, o livro pressupõe uma trajetória de ensino, um caminho que vai fazer o aluno entrar em contato com certos conhecimentos que em certos ordenamentos vão servir para sua formação. Essa trajetória de ensino sinaliza um percurso. Assim, é manifestado "um conceito de currículo definido em termos de projeto, incorporado em programas/planos de intenções que se justificam por experiências educativas" ". Nesse sentido, o livro didático apresenta uma proposta de currículo ao propor uma trajetória de ensino para o aluno e para o professor, e o currículo proposto pelo livro didático pode ter uma importância no processo de ensino/aprendizagem, tão grande quanto mais o curso for calcado na seqüência e nos conteúdos do livro.

Atualmente, encontram-se diferentes tipos de livros didáticos que tratam do mesmo assunto. Cada um possui um currículo implícito com objetivos, conteúdos secionados, formas de exercícios e propostas de avaliação. Alguns são muito parecidos, outros possuem propostas educacionais bem diferenciadas. Dentro dessa diversidade, o professor, ou a escola, tem que fazer uma seleção de livros. Para fazer essa seleção a

\footnotetext{
${ }^{9}$ PACHECO, José Augusto. Currículo: Teoria e Práxis. São Paulo, Porto Editora. 1996. pág. 16.
} 
escola ou o professor deve decidir como vai ser ensinado; como e quando esse conteúdo vai ser abordado; e para quem vai ser ensinado. Ao responder essas perguntas, o professor ou escola pode identificar qual o livro mais apropriado a ser aplicado. No entanto, a escola e professores sofrem, por exemplo, pressão dos pais dos estudantes acerca do que deve ser ensinado. E, por sua vez, os pais passam por uma pressão social que envolve determinada ideologia e representações.

O presente trabalho pretende fazer uma investigação dos currículos apresentados ou sinalizados em alguns livros didáticos de física do Ensino Médio, com particular atenção aos que tratam do ensino do eletromagnetismo. Assim, tem-se como objetivo realizar uma análise dos diferentes conceitos de currículos dos livros contemporâneos de eletromagnetismo.

Inicialmente, para realizar essa análise, é preciso primeiro entender o significado de currículo. No capítulo 3 são apresentados os conceitos e teorias de currículo, de TYLER, visão quase hegemônica entre 1918 e 1969, até EISNER (1992). Depois, no capítulo 4, é apresentada a teoria de currículo de Michael APPLE, primeiro faz-se uma comparação da teoria de APPLE com as demais teorias de currículo apresentadas no capítulo anterior e, em segundo, o texto se aprofunda nessa teoria. Nesse capítulo é colocado que, para APPLE, o currículo sofre a ação de vários agentes externos que possuem seus interesses. Logo, é necessário então estudar não só apenas os livros em si, mas também como eles interagem com nossa sociedade.

Só através dessas relações é possível entender as razões que levaram um livro didático a determinado conceito implícito de currículo. Ou seja, o conhecimento apresentado nos livros didáticos possui um conteúdo e uma forma que são moldados de acordo com alguns fatores externos. Esse conhecimento é selecionado previamente por grupos que determinam o que vai ser ensinado. Ou seja, o currículo tem uma relação complexa com a sociedade. Assim, para compreender melhor essa relação e o conceito de currículo do APPLE é necessário verificar como se incorporam os valores de uma ideologia através do conhecimento (conteúdo e forma) passado em sala de aula.

Esses fatores externos que influenciam o currículo são trabalhados no capítulo 5. Entre eles estão a legitimação do conhecimento através do livro didático, as influências da implementação de um currículo nacional e de uma avaliação nacional, as características internas de uma escola e a reprodução do conhecimento e de formas de trabalho e a ação da cultura e o comércio do livro didático. 
Tendo discutido o referencial teórico e no intuito de entender melhor a situação atual que nos encontramos, é realizado no capítulo 6 um levantamento histórico do desenvolvimento do currículo e de alguns livros didáticos associados a projetos de física no Brasil, entre eles o PSSC, FAI, PEF, PBEF e GREF. Essa abordagem é realizada levando em consideração a teoria de APPLE, ou seja, essa evolução é relacionada a fatores políticos, sociais e culturais de nosso país.

Após verificar os fatos históricos que levaram à configuração atual da realidade educacional brasileira, são discutidos no capítulo 7 quais os fatores atuais que estão presentes na educação no Brasil. Nesse capítulo tratam-se os Parâmetros Curriculares Nacionais - explicitando o que eles trouxeram na reformulação do conceito de aprendizagem, o Exame Nacional do Ensino Médio e os exames vestibulares.

O capítulo 8 reúne os principais elementos de todos os capítulo anteriores e discute a intenção desse trabalho e como através do referencial teórico será realizada a análise dos livros didáticos. Nos capítulos 9 e 10, é realizada a análise dos livros didáticos contemporâneos para o Ensino Médio que abordam conceitos de eletromagnetismo. O capítulo 9 apresenta uma proposta de critérios para análise, relacionados com os capítulos anteriores e explicados em termos do que foi neles discutidos. No capítulo 10, os critérios são utilizados na análise de três livros: o "Curso de Física" de Antônio Máximo e Beatriz Alvarenga, o "Leituras de Física Eletromagnetismo" (5 apostilas) do GREF / Grupo de Reelaboração do Ensino de Física e o "Os Fundamentos da Física", Vol. 3 - Eletricidade $8^{\text {a }}$ Edição 2003 do Francisco Ramalho Junior, Nicolau Gilberto Ferraro e Paulo Antônio de Toledo Soares. Por fim, é realizada, no capítulo 11, uma comparação entre os livros e uma conclusão sobre os aspectos levantados nesse trabalho.

O capítulo 12 traz uma breve reflexão e conjecturas sobre as idéias discutidas nesse trabalho, ao imaginar como a educação e a sociedade serão daqui a alguns anos e o que, quem sabe, tomará o lugar dos livros didáticos. 


\section{Teorias do Currículo: de TYLER a EISNER}

Inicialmente, para compreender e estudar as propostas de currículo inferidas nos livros didáticos de eletromagnetismo no Ensino Médio, é preciso determinar o que é currículo. O lexema currículo, de origem do étimo latino currere, significa caminho, trajetória, jornada ou percurso. Daí o uso do vocábulo de currículo, no séc XVII e nos paises anglo-saxônicos, para designar uma pista cíclica de atletismo ou pista para corrida de cavalos ou carros puxados por cavalos ${ }^{10}$. Dessa forma, o conceito de currículo é definido em termos do projeto educativo, incorporado em planos e/ou programas com objetivos que se justificam por ações educativas.

Esse conceito começou a ser estudado por alguns pesquisadores que começaram a propor suas primeiras definições de currículo. TYLER (1972), GOOD, BELTH, PHENIZ, TABA, JOHNSON, D’HAINAUT, foram alguns deles. Para José Augusto PACHECO, as primeiras definições de currículo correspondem a um plano de estudos, ou a um programa, muito estruturado e organizado na base de objetivos, conteúdos e atividades e de acordo com a natureza das disciplinas ${ }^{11}$. O currículo representa nessa acepção algo bem estruturado que será posteriormente aplicado tendo em vista intenções previstas. Os objetivos, então, expressam a antecipação de resultados, e os conteúdos a ensinar são, dessa forma, aspectos para a determinação do significado de currículo para esses autores.

De acordo com PINAR (1995), TYLER desenvolveu um paradigma curricular baseado na racionalidade e na lógica, que foi hegemônico de 1918 a 1969. Na década de setenta, os pesquisadores da área começaram a ver o currículo a partir de novos paradigmas, numa reconceptualização do campo. Os autores identificam algumas concepções de currículo que estão relacionadas com aspectos políticos, religiosos, de mercado, entre outros, a partir das quais podiam determinar objetivos, trajetórias de ensino, entre outros, de uma determinada instituição de ensino. Essas concepções, que muitas vezes eram contraditórias, mostravam a complexidade em definir um único conceito de currículo. No caso, a nomenclatura atribuída às concepções do currículo corresponde a uma compreensão do que é educação e de quais devem ser seus objetivos.

\footnotetext{
${ }^{10}$ PACHECO, José Augusto. Currículo: Teoria e Práxis. São Paulo, Porto Editora. 1996. Pág. 15.

${ }^{11}$ Ibid.
} 
Essa atitude foi seguida por diversos autores que começaram a criar suas próprias concepções de currículo. Dentre os trabalhos desenvolvidos se destacam EISNER e VALLANCE (1974), KLIEBARD (1987), GRUNDY (1991) e EISNER (1992).

Para DOMINGUES e $\operatorname{COSTA}^{12}$, esses pesquisadores se enquadram em duas abordagens em relação ao tema. EISNER, VALLANCE e KLIEBARD tratam o assunto dentro de uma perspectiva descritivo/analítica, como se "o currículo fosse independente e autônomo em relação ao contexto social no qual estão inseridos". Já GRUNDY faz parte de uma abordagem explicativa onde o currículo sofre influência da sociedade em que está inserido. Sendo assim, o currículo não é um conceito abstrato que tenha uma existência própria e à parte da experiência humana.

Para identificar e ajudar a distinguir a concepção de currículo proposta por esses autores, serão apresentados a seguir, brevemente, as idéias de cada um. A apresentação desses autores serve, no caso, para simples exemplificação das propostas de currículo desenvolvidas. Não se pretende nenhum aprofundamento das teorias em que cada qual esteja baseado.

Para EISNER e VALLANCE (1974), as concepções de currículo possuem valores, pressupostos subjacentes, que estão relacionados com o tipo de aluno que se quer formar e com a visão de mundo que se quer difundir. Esses autores identificam cinco concepções de currículo:

- $\quad$ currículo como desenvolvimento do processo cognitivo: que se preocupa com o processo de aprendizagem e o desenvolvimento das operações intelectuais, fazendo com que tenha instrumentos que o permita assimilar qualquer conteúdo;

- $\quad$ currículo como tecnologia, que centra no processo da aprendizagem, tendo um caráter neutro e voltado a eficácia do método de ensino;

- $\quad$ currículo como auto-realização, que entende a educação como uma força libertadora, que fornece meios para a liberação e o desenvolvimento pessoal através do conteúdo lecionado;

\footnotetext{
12 DOMINGUES, José Luiz e COSTA, Nilce Maria da Silva Campos. As concepções de currículo: uma revisão. A ser publicado.
} 
- $\quad$ currículo como reconstrução social, onde a educação é vista como um meio na qual a sociedade pode ser transformada (processo unilateral, a sociedade não transforma a escola);

- $\quad$ currículo como racionalismo acadêmico, tendo a intenção de fornecer ao estudante as grandes idéias criadas pelo homem.

KLIEBARD (1987) por sua vez faz uma análise histórica e observa quatro orientações de currículo:

- $\quad$ humanistas: detentores de um conhecimento que por tradição deve ser repassado através do poder da razão e de elementos da herança cultural ocidental;

- $\quad$ desenvolmentistas, entendem que as questões do currículo devem ser tratadas através de dados científicos obtidos no desenvolvimento do aluno e na natureza da aprendizagem;

- $\quad$ eficiência social, visa a escola tecnicista e direcionada às indústrias;

- $\quad$ aperfeiçoamento social, percebe a escola como a principal força para a mudança e justiça social.

Shirley GRUNDY (1991), insatisfeita com os fundamentos sobre teorias curriculares, decidiu elaborar uma nova teoria. Em sua teoria ela não propõe categorias, mas apresenta três propostas de currículo. Em sua idéia, baseada na teoria dos interesses cognitivos de HABERMAS, o currículo pode ser percebido como:

- $\quad$ produto, onde o currículo se realiza através de planos e programas de existência própria, independentes das experiências de aprendizagem. $\mathrm{O}$ professor tem como função executar esse currículo elaborado previamente. Logo, a ação seria um produto de uma idéia préestabelecida, produto que vem da ação de reproduzir. O conhecimento então é entendido como uma mercadoria que deve ser passada aos alunos. O intuito do conhecimento é que o aluno tenha controle sobre o meio em que vive; 
- $\quad$ prática, que leva em consideração o diálogo, a interação professoraluno, dentro de um processo de troca, deliberação e negociação. Sendo assim o currículo é construído dentro de uma troca de interesses entre alunos e professores e o conhecimento é visto como uma forma de interação do aluno com o seu meio;

práxis, que tem como objetivo a emancipação do ser humano. Nela existe uma ação conjunta com participantes ativos que visam à construção do conhecimento. Tal construção só poderia ser feita através da auto-reflexão e liberdade, entendida como respeito e fronteira para a liberdade do outro. A construção seria então um processo de discernimento da verdade e que desencadeia em uma transformação, e o conhecimento traria ao aluno uma autonomia, uma independência.

Em 1992, EISNER volta a estudar as concepções de currículo e as trata como ideologias de currículo. Sendo assim, as ideologias de currículo abrangem um conjunto de crenças, valores, visões de mundo que permeiam e induzem, de forma não explícita, a obtenção de determinados fins em educação. EISNER classifica seis tipos de ideologias de currículo:

- ortodoxia religiosa, que prega a existência de Deus e a importância de sua mensagem (na prática evita questionamento, a dúvida e a crítica aos princípios básicos da religião);

- humanismo racional, que centraliza a razão e construção humana, o reconhecimento de uma verdade (Iluminismo e Platão), um currículo comum para todos (uma leitura de igualdade) e um método de ensino articulado entre discussão, análise e debate;

- progressivismo, que enfatiza, através da teoria evolucionária de DARWIN e HEGEL, o desenvolvimento da inteligência e reforma social, respectivamente. DEWEY, indica que os pontos centrais dessa ideologia são a consideração da escola como transmissora de uma fórmula social e normas de convivência (além do currículo formal) e a hierarquia de decisões educacionais entre alunos e professores; 
- teoria crítica: fundamentada em MARX e com o objetivo de conscientizar pais, professores e alunos acerca das vias sutis nas quais ocorrem a injustiça social;

- reconceptualismo; enfatiza a experiência social, o imaginário e outras formas de conhecimento, trabalhando assim com atitudes fenomenológicas e indo contra o formato industrializado das escolas e a atitude mecanicista;

- pluralismo cognitivo; trabalha com a pluralidade de conhecimento e de inteligência e, conseqüentemente, das suas diferentes funções.

EINSNER, VALLANCE e KLIEBARD se preocuparam em gerar categorias que compreendem as concepções de currículo. Diferente de TYLER, que tinha um currículo baseado na racionalidade e na lógica. No entanto, essas teorias respondem as seguintes perguntas:

- O que pode e deve ser ensinado?

- Para quem?

- Como?

- Quando?

E a partir das respostas dadas, é possível ter um controle para verificar se os objetivos do currículo estão sendo cumpridos. Mas essas concepções não respondem as seguintes perguntas:

- Quem definiu o currículo?

- Quais são os objetivos das pessoas que definiram o currículo?

- Os objetivos dos alunos e professores estão presentes no currículo aplicado?

- Como a definição de um currículo, com seus objetivos, é propagada no ambiente escolar?

- Quem exerce controle para que esse currículo seja realizado?

- Como esse controle é exercido? 
Diferente dos autores apresentados, Michael APPLE aborda essas questões. Ele faz assim uma análise que leva em consideração questões históricas, econômicas e políticas. Ou seja, o currículo é visto como dependente desses fatores sociais, interagindo e sendo interagido, como se fosse um organismo vivo que se relaciona diretamente com seus agentes externos.

Dando continuidade às questões do currículo e dos livros didáticos, será apresentado no próximo capítulo um aprofundamento do conceito de currículo de APPLE. A partir desse texto será possível perceber as relações entre a educação e os demais setores de nossa sociedade, como política, cultura e economia. Nesse contexto, é realizado também um estudo sobre o significado de ideologia, hegemonia e cultura e suas relações com a aprendizagem. Tais relações, muitas vezes tênues, invisíveis no dia a dia, vão se mostrando cada vez mais nos outros capítulos, ao aproximar a base conceitual desse trabalho com a realidade educacional atual do nosso país.

São impressionantes os exemplos citados e as correlações realizadas. Na leitura, fica difícil não se assustar com o jogo de interesses que estruturam nossa sociedade atual. A primeira reação, ao ter contato com os textos de APPLE é a de repúdio, imaginando que se trata de um louco que escreve sobre uma grande conspiração. Depois, com um pouco mais de maturidade e compreendendo os exemplos e relações, percebe-se que realmente existe algo por trás de todas ações educacionais da sociedade.

O próximo capítulo pretende então, para melhor compreensão desse trabalho, formar uma base conceitual que vai guiar a análise dos livros contemporâneos que abordam eletromagnetismo e levantar alguns questionamentos referentes ao tema estudado. 


\section{O conceito de currículo de APPLE}

Como discutido no capítulo anterior, as diferentes teorias do currículo apresentam uma lista de princípios que tentam explicar a atividade escolar. Essas concepções, para APPLE, têm como objetivo tentar tornar mais eficiente a elaboração de currículos. Diz ele que:

"Durante a maior parte deste século, a educação em geral, e a área do currículo em particular, têm dedicado uma boa dose de energia á busca de uma coisa especifica: um conjunto geral de princípios que oriente o planejamento e a avaliação educacionais. Em grande parte, isto tem se reduzido a tentativas para criar um método mais eficiente de elaboração de currículos." 13

Sendo assim, os autores estavam focados em conseguir o melhor "rendimento" nas escolas e deixaram de observar o sistema maior onde a educação está inserida. Elementos presentes na sociedade, como a política e a cultura, estavam deixando de ser variáveis nas concepções de currículo.

“...fato de que a educação é, do começo ao fim, um empreendimento político, perdia importância. As questões que fazíamos tendiam a nos divorciar da forma como o aparato econômico e cultural da sociedade funcionava. Um método "neutro" significava nossa própria neutralidade, ou assim nos parecia. ...de modo geral, a fé na inerente neutralidade de nossas instituições, no conhecimento ensinado e em nossos métodos e ações, servia de forma ideal para ajudar a legitimar as bases estruturais da desigualdade." 14

Desconsiderar as questões externas à educação significa ter um método de ensino neutro que não leva em conta a realidade da sociedade. Realidade essa que é

\footnotetext{
${ }^{13}$ APPLE, Michael W. Educação e poder; trad. De Maria Cristina Monteiro. Ed. Artes Médicas, Porto Alegre, 1989. pág. 28

${ }^{14}$ Ibid, pág. 29
} 
fruto de nossa história, que representa o resultado de conflitos sociais. Realizar um estudo de currículo sem observar isso faz com que a pesquisa seja descontextualizada.

"As formas de pesquisa que muitos(as) estudiosos(as) educacionais empregam não são apenas o equivalente lógico de martelos e serras e, talvez, microscópios. Eles são também formas de estar com os outros. Eles têm uma política colada a eles. Tomar as pessoas como objetos isolados de estudo é também arriscar arrancá-las do tecido da história."15

Assumir essa postura é ser omisso às inúmeras dificuldades que enfrentamos, é perpetuar as injustiças e desigualdades. E, mais do que isso, é não perceber quem de fato está controlando o currículo.

"O currículo nunca é simplesmente uma montagem neutra de conhecimentos, que de alguma forma aparece nos livros e nas salas de aula de um país. Sempre parte de uma tradição seletiva, da seleção feita por alguém, da visão que algum grupo tem que seja o conhecimento legítimo. Ele é produzido pelos conflitos, tensões e compromissos culturais, políticos e econômicos que organizam e desorganizam um povo." 16

Entender o currículo então se torna uma ação extremamente complexa. É necessário ter inicialmente essa visão de que a educação não está separada dos outros setores da sociedade. Depois, é preciso notar que esses setores interagem com a educação através de ações políticas, culturais e econômicas. E tal interação sempre converge para os interesses de um determinado grupo.

“Assim, queiramos ou não, diferentes forças se introduzem no próprio coração do currículo, do ensino e da avaliação. O que conta

\footnotetext{
${ }^{15}$ APPLE, Michael W, Ideology and Curriculum. Ed. Routledge \& Kegan Paul, Boston e Londres, 1979 citado em APPLE, Michael W. Trabalho docente e textos: economia política das relações de classe e de gênero na educação; trad. De Thomaz Tadeu da Silva, Tina Amado e Vera Maria Moreira. Ed. Artes Médicas, Porto Alegre, 1995. pág. 7.

${ }^{16}$ APPLE, Michael. Política cultural e educação; trad. De Maria José do Amaral Ferreira. Ed Cortez, São Paulo, 2000. pág. 53
} 
como conhecimento, as formas as quais ele está organizado, quem tem poder de ensiná-lo, o que conta como demonstração apropriada de sua aprendizagem - um aspecto tão critico quanto os anteriores - a quem é permitido fazer todas essas questões e respondê-las, tudo isso faz parte de como a dominação e subordinação são reproduzidas e alteradas na sociedade. ${ }^{17}$

O currículo mais que um mero personagem da educação é um meio de controle de um determinado grupo sobre todo o povo. A escola, nesse sentido, é um aparelho que tenta definir, que tenta formatar o futuro cidadão que será um subordinado de um grupo de elite, um ser que aceita todas as regras impostas, que aceita sua situação na sociedade e não a questiona. Sobre esse assunto, Michael YOUNG comenta que:

"...aqueles que estão em posições de poder tentarão definir o que deve ser tido como saber na sociedade, quão acessível a cada grupo cada saber é e quais são as relações aceitas entre diferentes áreas de saber e entre aqueles que têm acesso a elas e as tornam disponíveis." 18

Partindo de Bernstein (1973), o currículo, abordado como saber socialmente organizado, origina em três questões que se inter-relacionam ${ }^{19}$ :

1. Estratificação do saber: a estratificação do saber, realizada por aqueles que têm o poder de definir o que é saber valorizado, passa por certos critérios. Em particular, a estratificação tem dois aspectos, o "prestígio" e a "propriedade". As diferenças de prestígio se referem às formas como diferentes tipos de saber são avaliados. Já o aspecto de propriedade da estratificação do saber está relacionado em como o acesso ao saber é em ampla medida controlado.

2. A restrição do acesso a determinadas áreas do saber a grupos específicos é também uma questão que envolve poder. A distribuição do saber para os

\footnotetext{
${ }^{17}$ APPLE, Michael. Política cultural e educação; trad. De Maria José do Amaral Ferreira. Ed Cortez, São Paulo, 2000, pág. 54

${ }^{18}$ YOUNG, Michael. O Currículo do futuro: da "nova sociologia da educação" a uma teoria crítica do aprendizado. Campinas, SP: Papirus, 2000. Pág. 30.

${ }^{19}$ Ibid.
} 
alunos, em diferentes idades, no âmbito do currículo, também passa por essa questão.

3. Por fim, as relações entre áreas de saber significam expressões de poder. Nesse caso, o poder que alguns estudantes têm de manter ou derrubar limitações do saber.

APPLE explica que os professores, em geral, não estão conscientes que algumas de suas ações educativas, tomadas no dia a dia de seu trabalho, têm desempenhado funções que não vão na direção das nossas melhores intenções. ${ }^{20}$

Muitas vezes os professores não notam todas essas questões pois vêem, como os autores de currículo, a educação de forma separada da sociedade. E, assim, não conseguem perceber a complexa estrutura em que a educação está relacionada. Por exemplo, nos Estados Unidos:

“Os(as) educadores(as) estão freqüentemente impedidos(as) de reconhecer essas relações e sua própria posição nessa crise, por uma série de razões. Por não ver a educação de forma relacional, por não vê-la como resultado de conflitos econômicos, políticos e culturais que historicamente emergiram nos Estados Unidos e em outros países, eles (elas), com demasiada freqüência, colocam as questões educacionais num compartimento estanque, que dificilmente concede espaço para a interação com as relações de classe, sexo e poder racial que dão à educação seu significado social. “21

Por outro lado, alguns educadores também não tiveram interesse de ir além da simples prestação de serviços aos estudantes. Mas podem seus motivos, suas ações, possuírem uma carga ideológica tão forte? E como seria essa relação entre ideologia e currículo. APPLE diz que:

\footnotetext{
${ }^{20}$ APPLE, Michael W. Educação e poder; trad. De Maria Cristina Monteiro. Ed. Artes Médicas, Porto Alegre, 1989. pág. 29.

21 GITLIN, Todd. Television"s Screens: Hegemony in Transition, citado em APPLE, Michael W. Trabalho docente e textos: economia política das relações de classe e de gênero em educação; trad. Thomaz Tadeu da Silva, Tina Amado e Vera Maria Moreira. Ed. Artes Médicas, Porto Alegre, 1995, pág. 
"Os estudos das interligações entre ideologia e currículo e entre ideologia e retórica educacional apresentam importantes implicações para a área do currículo e para a teoria e a política educacional em geral. Pois, como demonstrarei ao longo desta obra, precisamos examinar criticamente não apenas "como um estudante adquire mais conhecimento", mas "por que e como determinados aspectos da cultura coletiva são apresentados na escola como conhecimento objetivo, factual”.,22

Sendo assim, para entender melhor a situação, é necessário um maior entendimento do conceito de ideologia. O problema é que não existe um consenso sobre o significado de ideologia. Para muitas pessoas o termo ideologia faz referência " $a$ algum tipo de "sistema" de idéias, crenças, compromissos fundamentais ou valores quanto à realidade social”,23.

Os autores que escrevem sobre ideologia apresentam também orientações divergentes do conceito de ideologia. No entanto, APPLE indica que existem três características comuns entre todos os autores: a legitimação, o conflito de poder e um estilo de argumentação. McClure e Fischer descrevem com clareza cada uma dessas características. A seguir são apresentadas duas características que são importantes para esse trabalho, a legitimação e a luta pelo $\operatorname{poder}^{24}$ :

1) Legitimação - Os sociólogos parecem estar de acordo quanto ao fato de que a ideologia está relacionada à legitimação - a justificação da ação de um grupo e sua aceitação social. Isto é válido quer os autores falem de racionalização do capital investido, de tentativas de "manter um determinado papel social”, quer falem de atividade justificatória, (...) relacionada ao estabelecimento e à defesa de padrões de opinião. Em cada caso, tratam como uma questão primordial à legitimação da forma como uma atividade é socialmente organizada (...) Quando as suposições básicas subjacentes a um programa social parecem estar sendo seriamente desafiadas, a

\footnotetext{
22 APPLE, Michael W. Ideologia e Currículo. Ed. Brasiliense, 1982. pág 26

${ }^{23}$ Ibid, pág 35

${ }^{24}$ Ibid, pág 36
} 
conseqüente necessidade de legitimação pode também tomar a forma de interesse pelo sagrado. (...) "A ideologia procura sacralizar a existência submetendo-a ao domínio dos princípios fundamentalmente corretos."

2) Luta pelo poder - Toda a literatura sociológica liga a ideologia às lutas pela procura ou pela preservação do poder. Mas alguns autores têm em mente o poder, ou a política, num sentido mais restrito, ao passo que outros num sentido mais amplo. No sentido mais restrito, esses termos se referem à distribuição formal, numa sociedade, de autoridade e recursos, o que de modo geral ocorre dentro de um domínio - a esfera política. No sentido mais amplo, o poder e a política envolvem qualquer esfera de atividade, e todos os seus aspectos que tratam da distribuição de recompensas (...) A luta pelo poder está sempre em jogo nas disputas ideológicas, quer ou não os implicados reconheçam expressamente essa dimensão.

Essas duas características apresentam importantes implicações para uma segunda análise da educação, uma análise hegemônica. Para Raymond WILLIANS:

"a hegemonia pressupõe a existência de alguma coisa que é verdadeiramente total, que não é apenas secundária, ou superestrutural, como o fraco sentido de ideologia, mas sim que é vivenciada tão profundamente, que satura a tal ponto a sociedade e que, conforme Gramsci, constitue mesmo o limite do senso comum para a maioria das pessoas que se acham sob seu domínio, que acaba por corresponder à realidade da experiência social de modo muito mais nítido do que quaisquer outras noções derivadas da fórmula de base e superestrutura",25.

Assim, a ideologia hegemônica constitui a realidade para a maioria das pessoas, pois esse conjunto de significados e valores são vividos, testados, sentidos. A ideologia

\footnotetext{
${ }^{25}$ APPLE, Michael W. Ideologia e Currículo. Ed. Brasiliense, 1982. pág. 14.
} 
hegemônica é então um processo social, dinâmico e real. Assim, as pessoas não questionam determinados valores e significados, pois os entendem como verdade, verdade essa que é exaustivamente comprovada no dia a dia.

O difícil é fazer o contrário, tentar experimentar algo que não é hegemônico, algo que "não está em nossa realidade". A dificuldade em viver o "novo" está no processo da quebra da hegemonia. É como imaginar ou fazer algo que não está presente no senso comum. Para compreender melhor uma cultura efetiva e dominante é preciso entender o meio que faz com que as pessoas aceitem determinada idéia ou valor, o processo de incorporação.

“Os modos de incorporação são de grande significado, e incidentalmente em nosso tipo de sociedade apresentam considerável importância econômica. As instituições educacionais são em geral os principais agentes de transmissão de uma cultura dominante efetiva, $e$ esta é agora uma importante atividade econômica bem como cultural; na verdade são as duas simultaneamente.

E, ao passar uma cultura dominante efetiva, a escola também realiza uma seleção de práticas, conteúdos, valores, entre outros. Esse processo de seleção é chamado por WILLIANS de tradição seletiva. No caso, essa seleção é justificada pela prerrogativa da tradição, do passado significativo. Com isso, a escola transmite apenas aquilo que é de interesse de um determinado grupo. $\mathrm{O}$ aluno, dentro de um sistema de incorporação, aceita tais valores e, como conseqüência, a cultura dominante efetiva se mantém.

Sendo assim, o conceito de hegemonia implica que:

"os padrões fundamentais numa sociedade são ligados por suposições ideológicas tácitas, regras, se assim se quiser denominálas, que em geral não são conscientes, bem como por controle e poder econômico. Essas regras servem para organizar e legitimar a atividade de muitos indivíduos cuja interação constitui uma ordem social."27

\footnotetext{
${ }^{26}$ Ibid. pág. 15

${ }^{27}$ Ibid. pág 131
} 
Por isso, é muito importante fazer as seguintes perguntas: Por que o conhecimento é organizado e transmitido dessa forma? Quem selecionou tal conhecimento? A quem pertence esse conhecimento?

As escolas então não apenas formam as pessoas, mas também preparam o conhecimento, desempenham novas funções, são agentes de hegemonia cultural e ideológica, agentes da tradição seletiva e da incorporação cultural. ${ }^{28}$ Essa incorporação faz com que os membros da sociedade se tornem dóceis, aceitem com facilidade regras impostas e não questionem a ordem estabelecida. Madeleine MACDONALD diz que "essa aparente estabilidade social e ideológica está em parte baseada na inteorização profunda e em geral inconsciente pelo indivíduo dos princípios que governam a ordem social existente, 29

A educação e o processo da educação, que se realizam através do currículo, para BOWLES e GINTIS ${ }^{30}$, estabelecem o lugar dos indivíduos em uma sociedade, sociabilizando as pessoas a aceitarem como legítimos os limitados papéis que elas futuramente exercerão na sociedade.

Diz Paulo FREIRE que:

"O poder da ideologia me faz pensar nessas manhãs orvalhadas de nevoeiro em qual mal vemos o perfil dos ciprestes como sombras que parecem muito mais manchas das sombras mesmas. Sabemos que há algo metido na penumbra mas não o divisamos bem. A própria "miopia" que nos acomete dificulta a percepção mais clara, mais nítida da sombra. Mais séria ainda é a possibilidade que temos de docilmente aceitar que o que vemos e ouvimos é o que na verdade é, e não a verdade distorcida". 31

No caso do ensino de áreas ligadas ao conhecimento cientifico, como a física, essa postura faz com que o conhecimento seja organizado apenas em torno de algumas regularidades fundamentais, desconsiderando assim toda história significativa de debate

\footnotetext{
${ }^{28}$ Ibid, pág 16

29 MACDONALD, Madeleine. The Curriculum and Cultural Reproduction. Milton Keynes, Open University Press, 1977, p.60. citada em APPLE, Michael W. Ideologia e Currículo. Ed. Brasiliense, 1982. pág 52

${ }^{30}$ MEYER, John W. The effects of Education as an Institution. American Journal of Sociology, LXXXIII (July 1977), 64 citado em APPLE, Michael W. Ideologia e Currículo. Ed. Brasiliense, 1982. pág 52

${ }^{31}$ FREIRE, Paulo. Pedagogia da Autonomia. Ed. Paz e Terra, 1996. Pág. 126.
} 
intelectual e inter-pessoal que foi construída ao longo do tempo por indivíduos e grupos de estudiosos.

“Em geral, o conflito é gerado pela introdução de um paradigma novo e quase sempre revolucionário que desafia as estruturas básicas de significado anteriormente aceitas pelo corpo de cientistas, dividindo, desse modo, efetivamente a comunidade. Esses debates estão relacionados aos modos de aquisição de conhecimento verificável, ao que se deve considerar como exatamente cientifico, aos próprios fundamentos básicos sobre os quais se sustém a ciência. ${ }^{32}$ ",

Logo, o retrato da quebra da hegemonia, da revolução, do novo não é ensinado aos alunos, pois isso pode fazer com que o estudante adquira uma postura mais crítica, questionando assim a cultura efetiva e dominante. De acordo com Warren HAGSTROM, o conhecimento cientifico encontrado nas escolas é colocado a parte da sociedade. Diz ele que:

\begin{abstract}
"Em nossas escolas, o trabalho cientifico está sempre tacitamente ligado aos padrões aceitos de validade e é visto (e ensinado) como sujeito sempre à verificação empírica sem influências externas, quer pessoais ou políticas. As diferentes formas de ciência não existem ou, se existem, são empregados critérios "objetivos" para persuadir os cientistas de que lado esta correto e o outro errado." 33
\end{abstract}

Ao mostrar constantemente apenas os resultados das pesquisas, o consenso cientifico, o estudante não observa as discordâncias e controvérsias que certas teorias tiveram quando foram elaboradas. E, ao não ver isso, também não percebe como foram importantes as discordâncias e controvérsias para que a ciência avançasse. A investigação de problemas fundamentais e a elucidação de posições intelectuais conflitantes só podem ser obtidas através da discussão, do conflito de idéias.

\footnotetext{
32 APPLE, Michael W. Ideologia e Currículo. Ed. Brasiliense, 1982. pág. 134

${ }^{33}$ HAGSTROM, Warren. The Scientific Community. New York, Basic Books, 1965, p. 256 citado em APPLE, Michael W. Ideologia e Currículo. Ed. Brasiliense, 1982. pág. 135
} 
O padrão de objetividade da ciência demonstrada nas escolas faz com que o aluno veja uma separação entre ciência e política. Logo, o cientista fica representado como um indivíduo que verifica ou sintetiza racionalmente suposições comprovadas ou que desenvolve e testa hipóteses, descartando assim possíveis dimensões políticas do processo pelo qual um cientista consegue legitimar determinado conceito cientifico.

De acordo com ZANETIC, no Brasil,

"a física ensinada em nossas escolas é, com poucas exceções, dominada pela apresentação em linguagem matemática dos conceitos e leis e de sua aplicação operacional, metodologicamente pobre, sem experimentos, sem história internalista ou externalista e desligada da vivência dos alunos e da prática dos cientistas. Por tudo isso, a física ensinada nas escolas, a física escolar, nasce sob o signo do distanciamento tanto com relação à física desenvolvida nos centros de pesquisa, quanto com a possibilidade de se estabelecer um diálogo produtivo com o mundo que nos cerca"34.

Sendo assim, a escola, além de não apresentar o conflito histórico e contínuo de teorias que se contradizem, não dá atenção ao fato de que a verificação de hipóteses e a aplicação de critérios científicos existentes são insuficientes para explicar como e por que se faz uma escolha entre teorias antagônicas. Há muitos contra-exemplos que desfiguram essa visão de ciência. ${ }^{35}$ A ciência não é de todo acumulativa e nem procede de acordo com algum critério de bom senso, pelo contrário, se desenvolve por revoluções conceituais que fazem com que os grupos de cientistas revejam seus modelos com os quais procuram entender e manipular o mundo. ${ }^{36}$

Ao não ter essa visão de ciência os estudantes passam a ter um quadro irrealista de como as comunidades cientificas disputam o poder e os recursos econômicos. Com isso, os estudantes interiorizam "uma visão que pouco questiona a legitimidade das suposições tácitas sobre o conflito inter-pessoal que dirigem suas vidas e suas próprias

\footnotetext{
${ }^{34}$ ZANETIC, João. Apostila da disciplina Propostas e Projetos de Ensino de Física. IFUSP, 2000. Pág.2.

35 KUHN, Thomas. The Structure of Scientific Revolutions. $2^{\circ}$ ed. University odf Chicago Press, 1970. citado em APPLE, Michael W. Ideologia e Currículo. Ed. Brasiliense, 1982. pág. 136

${ }^{36}$ LAKATOS, Imre. Falsification and the methodology of Scientific Research Programmes. Criticism and the Growth of Knowledge. Imre Lakatos e Alan Musgrave (orgs.). New York, Oxford Universtity Press, 1970, p.155 citado em APPLE, Michael W. Ideologia e Currículo. Ed. Brasiliense, 1982. pág. 136
} 
situações educacionais, econômicas e políticas" ${ }^{37}$, além de não perceberem o quão é importante as divergências entre grupos e inter-pessoal, que impulsionaram o progresso.

Em uma perspectiva generalizada, a falta do conflito, da discussão de idéias, a busca pelo novo, faz com que sejam mantidos os paradigmas das atividades econômicas e políticas de uma sociedade. No livro Notas Autobiográficas, de Albert EINSTEIN, por exemplo, fica muito claro, ao longo do texto, a presença de uma série de questionamentos e dúvidas que cercaram sua vida como cientista, indo das críticas à mecânica clássica, passando pela radiação do corpo negro e chegando em algumas discussões sobre campo gravitacional, e que demonstram uma fonte rica de elementos, colocados em debate e que compõem o desenvolvimento da física. Em um trecho ímpar, mais voltado para a vida pessoal de Einstein, fica registrada a influência e força que os textos podem ocasionar. Nele, Einstein comenta da presença da religião, implantada nas crianças pela máquina educadora tradicional ${ }^{38}$. Diz que:

“...embora fosse filho de pais absolutamente não-religiosos (judeus) - , entreguei-me a uma religiosidade profunda, que terminou abruptamente quando tinha apenas doze anos. A leitura de livros científicos populares convenceu-me de que a maioria das histórias da Bíblia não podia ser real. A conseqüência foi uma orgia positivamente fanática de livre-pensamento, combinada com a impressão de que a juventude é decididamente enganada pelo Estado, com mentiras; foi uma descoberta esmagadora." 39

E, tal constatação, fez com que ele passasse, por muito tempo, a desconfiar de todo tipo de autoridade, tomando assim uma postura cética quanto às convicções vigentes. Essa postura questionadora é importante para que uma pessoa tenha um olhar crítico frente às questões da sociedade. E, ao tratar a ciência como uma mera apresentação de conceitos e leis, em linguagem matemática, sem experimentos e desenvolvimento histórico, o aluno acaba por ter uma visão antiga do conceito de ciência. Para entender melhor isso e as novas visões de ciências, e suas relações com o

\footnotetext{
${ }^{37}$ APPLE, Michael W. Ideologia e Currículo. Ed. Brasiliense, 1982. pág. 140

${ }^{38}$ EINSTEIN, Albert. Notas Autobiográficas. Ed. Comemorativa / traduzida e anotada por Paul Arthur ; tradução de Aulyde Soares Rodrigues, - Rio de Janeiro: Nova Fronteira, 1982. Pág. 14.

${ }^{39}$ Ibid.
} 
contexto social, é preciso entender com o conceito de ciência evoluiu ao longo do tempo.

Antigamente, muitos pensadores e filósofos se indagaram sobre o significado da ciência. Entre eles, GALILEU propôs uma nova ciência, que tinha três características fundamentais $^{40}$ : autonomia, se distanciando da teologia e da autoridade livresca da tradição aristotélica; a aplicação do método experimental como meio de se chegar ao conhecimento; e a linguagem matemática como meio de apresentação de leis e teorias. No livro Diálogo dos Grandes Sistemas, GALILEU comenta, sobre a autonomia da ciência que:

“ os efeitos naturais e a experiência sensivel que se oferece aos nossos olhos, bem como as demonstrações necessárias que daí retiramos não devem, de maneira alguma, ser postas em dúvida, nem condenadas em nome de passagens da Escritura, mesmo quando o sentido literal parece contradizê-las." ${ }^{41}$

O método experimental também foi um grande salto. Para GALILEU, a experiência servia para provar determinada idéia. Diz, que:

"Ao cientista só se deve exigir que prove o que afirma. (...) Nas disputas dos problemas das ciências naturais, não se deve começar pela autoridade dos textos bíblicos, mas sim pelas experiências sensatas e pelas demonstrações indispensáveis." 42

Desse modo, a ciência podia ser construída através da repetição de experiências, tantas vezes quantas as necessárias, para registrar com precisão os resultados alcançados. Além disso, o uso da linguagem matemática permitiu a medição e quantificação de variáveis de um problema. Isso reforçou ainda mais a relação entre experiência e a linguagem matemática.

Depois, DESCARTES (1596-1656) e NEWTON, com o mecanicismo, indicaram um novo significado para ciência. Nessa proposta a natureza era vista como

\footnotetext{
${ }^{40}$ ALMEIDA, Aires. Filosofia e ciências da natureza: alguns elementos históricos. Centro de Filosofia e Ciências Humanas / Universidade Federal de Santa Catarina. http://www.cfh.ufsc/ wfil/aires.htm. $10 / 09 / 05$.

${ }^{41}$ Ibid.

${ }^{42}$ Ibid.
} 
um mecanismo que tem um funcionamento que se rege por leis precisas e rigorosas. $\mathrm{O}$ mundo, no caso, poderia ser todo traduzido por leis mecânicas. Essa proposta segue a idéia do reducionismo, onde podemos reduzir alguns fenômenos de um certo tipo a fenômenos de outro tipo.

No século XIX, o mecanicismo não se adequou à visão de MAXWELL (18311879), que mostrou que a radiação eletromagnética e os campos eletromagnéticos não tinham uma "natureza mecânica".

Em relação à conexão da experiência com a ciência, o filosofo David HUME (1711-1776) comenta, no Ensaio sobre o Entendimento Humano, "que tudo o que sabemos procede da experiência, mas que esta apenas nos mostra como as coisas acontecem e que não é impossível que acontecem de outra maneira”. ${ }^{43}$ Assim, HUME apresenta o papel do observador no entendimento de um fenômeno. Diz que os nossos sentidos não nos permitem formular juízos universais. Por exemplo, a observação da queda de muitas folhas não nos autoriza a concluir que todas as folhas caem necessariamente. Essa idéia de HUME, contrária à de Galileu, traz uma nova visão sobre o que é ciência. Nessa linha, KANT (1724-1804) diz que o entendimento humano não se limita às observações captadas pelos seus sentidos. No livro Crítica da Razão Pura, KANT relata que a experiência não concede nunca aos seus juízos uma universalidade verdadeira e rigorosa, apenas universalidade suposta e comparativa. Quando um cientista, por exemplo, afirma que nenhum corpo pode chegar à velocidade da luz, ele está dizendo, para KANT, que um fenômeno está sendo formulado em uma proposição necessária e universal, mas que não se refere à natureza intima do mundo, mas sim como nós, seres humanos, conhecemos o mundo.

No século XIX, com o avanço cientifico e tecnológico e o desenvolvimento e aparecimento de novas ciências, como a psicologia, o significado de ciência começou a se tornar mais complexo. Auguste COMTE (1798-1857), com o positivismo, começou a repensar a ciência. COMTE considera que a ciência conseguiu superar as concepções mítico-religiosas, formando assim um novo pensar. Nele, é reconhecida a impossibilidade de se obter noções absolutas e, por isso, renuncia a busca pela origem e destino do universo. E, ao renunciar, começa a se dedicar apenas à descoberta, pelo uso do raciocínio e observação e das suas relações invariáveis de sucessão e similitude. $\mathrm{O}$ pressuposto fundamental na filosofia positivista é que há uma regularidade no

${ }^{43}$ Ibid. 
funcionamento da natureza e que o homem busca as leis naturais invariáveis a que todos os fenômenos estão submetidos.

Atualmente, a ciência é pensada pela "nova" filosofia da ciência, ou teoria globalista da ciência. Antecedentes desta abordagem, do século passado, remontam, para Osvaldo PESSOA Jr. ${ }^{44}$, ao filósofo da ciência francês Gaston BACHELARD ( $O$ Novo Espírito Cientifico, 1934) e na década de 50 incluem pensadores como Michael POLANI, Willard QUINE, Paul FEYERABEND, Norwood HANSON e Stephen TOULMIN. Mas, quem teve maior repercussão, e que apresentou idéias que estão presentes no pensamento dos globalistas, foi o historiador Thomas KUHN, em particular no livro A Estrutura das Revoluções Científicas (1962). Nele, para PESSOA, se destacam as seguintes características ${ }^{45}$ :

A) A distinção entre linguagem observacional e linguagem teórica deixou de ser clara. Uma das razões para isso pé que qualquer observação é impregnada pela teoria do observador (HANSON), que interpreta sua percepção com base em uma teoria. Além disso, uma observaçãofeita com um instrumento só pode ser corretamente interpretada conhecendo-se a teoria do funcionamento do instrumento.

B) A transição de uma teoria para outra não é mais vista com uma ampliação cumulativa de conhecimento, mas como uma ruptura (BACHELARD).

C) Os méritos de uma teoria não se restringem meramente às suas conseqüências observacionais, avaliadas por procedimentos lógicos de confirmação ou falseamento. O contexto social e histórico tornam-se relevantes para entender porque uma teoria é preferida em relação a outra.

D) A distinção entre contexto da justificação e contexto da descoberta é apagada. Os detalhes de como um avanço cientifico foi obtido é relevante para a filosofia da Ciência.

\footnotetext{
${ }^{44}$ PESSOA, Osvaldo Jr. Filosofia \& Sociologia da Ciência: Uma Introdução. http:/www.cfh.ufsc.br/ wfil/sociociencia.htm 21/09/05.

${ }^{45}$ Ibid.
} 
E) Rejeita-se o "funcionalismo" do empirismo lógico, ou seja, a idéia de que uma teoria cientifica se assenta em bases sólidas fornecidas por "dados observacionais".

F) Deixa-se de valorizar a observação, passando se a enfocar a teoria.

KUHN defende que a ciência evolui através de "revoluções". Uma revolução começa quando uma teoria, devido ao surgimento de anomalias ou problemas não resolvidos, entra em crise. Para superar a crise, esperasse o aparecimento de um novo paradigma que resolva os problemas, levando a uma rejeição do paradigma anterior. $\mathrm{Na}$ concepção de KUHN, paradigma é toda a constelação de crenças, valores, problemas, metas, etc...que é compartilhada por membros de uma dada sociedade. ${ }^{46}$ Nesse sentido, uma teoria cientifica não é melhor por conta de prover uma representação mais fiel ao mundo, mas porque ela consegue formular e resolver mais questões.

A visão de ciência de KUHN é, de certa forma, muito próxima às questões levantadas por APPLE. O estudante, ao ver a ciência levando em consideração o contexto social e histórico, vai poder refletir e entender as relações entre a ciência e a sociedade. Com isso, o aluno pode ter uma postura questionadora e ativa, pois a reflexão sobre ciência e sociedade pode fazer com que se inicie uma reflexão entre a vida cotidiana do aluno e sua sociedade. Com a consciência de uma ciência que evolui através de conflitos, discussão de idéias e busca pelo novo, pode também começar uma busca de transformação e de paradigmas das atividades econômicas e políticas de uma sociedade

Do contrário, o estudante pode entender a ciência como algo acabado, definido e estático. Para Ruth Schimitz de CASTRO:

"Encarar a ciência como um produto acabado confere ao conhecimento cientifico uma falsa simplicidade que se revela cada vez. mais como uma barreira a qualquer construção, uma vez que contribui para a formação de uma atitude ingênua frente à ciência. Ao encararmos os conteúdos de ciências como óbvios, as diversas redes de construção edificadas para dar suporte a teorias sofisticadas

\footnotetext{
${ }^{46}$ Ibid.
} 
apresentam-se como algo natural e, portanto, de compreensão imediata. Assim o conhecimento cientifico, construção sofisticada e gradual na mente humana, passa a ser tomado como algo passível de transmissão, de revelação e não como conhecimento a ser elaborado. Essa atitude mostra-se claramente nociva a qualquer tentativa de se aproximar da ciência." 47

Logo, a ciência apresentada como algo acabado, definido e estático leva à imagem de verdade a ser aceita, presente em muitos livros didáticos. Frederico F.S. CRUZ diz que:

“... na Física estamos mais acostumados com o resultado de um conhecimento que funciona, que aparentemente está aí, que dá certo e no qual a gente acredita, tem uma certa fé. Uma coisa que está por trás disto, e não sei se a gente pode classificar como uma certa ideologia, é que o conhecimento em Física se pretende seja incorruptível, a-histórico, sem dinâmica, mais ou menos eterno (...) E é o que está muito presente nos livros pela linearização que eles fazem do conhecimento empírico." 48

Essa vertente é denominada, pelos filósofos da ciência, de cientismo. Dizem que, na sociedade moderna, a ciência tornou-se objeto de confiança ilimitada. Para Aires ALMEIDA, o cientismo, que é a ciência transformada em ideologia, assenta em uma atitude dogmática de esperar que a ciência responda a todas as perguntas e resolva todos os problemas. Diz que, em grande medida, "o cientismo resulta de uma compreensão errada da própria ciência" ${ }^{49}$.

Portanto, para se ter a ruptura com essa visão de ciência e uma formação ativa e questionadora é preciso que o currículo de ciências contemple determinadas

\footnotetext{
47 CASTRO, Ruth Schimitz de. História da Ciência: investigando como usá-la num curso de segundo grau. Cad. Cat. Ens. Física, 9 (3). Pág. 227.

${ }^{48}$ CRUZ, Frederico F. S. Mesa redonda: influência da historia da ciência no ensino de física. Cad. Cat. Ens. Física, 5 (número especial). Pág. 76.

${ }^{49}$ ALMEIDA, Aires. Filosofia e ciências da natureza: alguns elementos históricos. Centro de Filosofia e Ciências Humanas / Universidade Federal de Santa Catarina. http://www.cfh.ufsc/ wfil/aires.htm. 10/09/05
} 
características, como a história e filosofia da Ciência. E, de acordo com Cássio Costa LARANJEIRAS, a história e filosofia da Ciência:

“devem estar a serviço da explicitação da dinâmica do processo de construção do conhecimento cientifico. Mais do que fazer o aluno compreender o que é correto ou não, elas devem estar a serviço da problematização do que Paulo C. C. Abrantes chama de "imagens de ciência" - "visões que são mais ou menos correntes sobre como se adquire conhecimento cientifico, como se trata uma teoria, as questões filosóficas a respeito do conhecimento cientifico, questões a respeito de como a Historia da Ciência se desenvolve, as relações entre ciência e sociedade ${ }^{, 50}$

Essas diferentes imagens, que remontam as questões filosóficas, retiram uma visão hegemônica da ciência, possibilitando uma educação de interação e discussão em sua construção, ocasionando uma postura ativa e crítica do discente. Mas, a escola, ao promover a passividade do aluno, através de um rigoroso controle, que faz com que os estudantes interiorizem regras fundamentais de pensamento sem que estas sejam questionadas, legitima a cultura efetiva e dominante. Isso resulta em um controle da sociedade, controle esse que é aceito, pois as pessoas acreditam na visão de conhecimento estabelecida.

Diz FREIRE que:

"A capacidade de nos amaciar que tem a ideologia nos faz às vezes mansamente aceitar que a globalização da economia é uma intervenção dela mesma ou de um destino que não poderia se evitar, uma quase entidade metafísica e não um movimento do desenvolvimento econômico submetido, como toda produção econômica capitalista, a uma certa orientação politica ditada pelos interesses dos que detêm o poder. “"51

No entanto, não é fácil vencer uma ideologia imposta. Para FREIRE a ideologia tem poder de persuasão muito grande. O discurso ideológico tende a nos anestesiar a

\footnotetext{
50 LARANJEIRAS, Cássio Costa. Redimensionando o ensino de física numa perspectiva histórica. São Paulo, 1994. Dissertação de Mestrado - Universidade de São Paulo / Instituto de Física

${ }^{51}$ FREIRE, Paulo. Pedagogia da Autonomia. Ed. Paz e Terra, 1996. Pág. 126.
} 
mente, de confundir a curiosidade, de distorcer a percepção dos fatos, das coisas, dos acontecimentos $^{52}$. Não podemos escutar o discurso ideológico sem ter o mínimo de reação crítica. E essa postura crítica deve estar presente na formação dos estudantes. Só dessa forma será possível construir valores que emergem da cultura e que ganham significados pelo próprio estudante. E, para FREIRE, precisamos propor aos estudantes, através de certas contradições básicas, sua situação existencial, concreta, presente, como problema que, por sua vez os desafia e, assim, lhes exige resposta, no nível intelectual e na decorrente ação ${ }^{53}$.

Uma forma de propor isso é através dos temas geradores ${ }^{54}$. Nessa proposta, o professor inicialmente pesquisa o universo temático onde se localizam seus alunos (Investigação Temática) $^{55}$. A partir dessa investigação, o docente procura um conjunto de temas que estão presentes na vida do aluno e que podem ser apresentados na escola (Tematização). Em sala de aula, o professor apresenta os temas que são escolhidos e debatidos com os estudantes (Problematização). Esse tema, que traz dúvidas e questões, proporciona uma problematização da realidade do aluno. Assim, a atividade educacional se torna um conhecimento da realidade concreta, da situação real cotidiana do estudante e só tem sentido se resultar em uma aproximação crítica dessa realidade.

Do contrário, tanto para o aluno quanto para o professor, o currículo acaba sendo apenas uma seleção de conhecimentos determinada por outras pessoas. E, essa seleção, que é determinada por certas pessoas, impõe uma ideologia que é imposta nas escolas. Ou seja, para compreender o currículo é necessário entender quais variáveis sociais estão interligadas com a educação. E, mais do que reconhecer essas variáveis, é preciso também saber quais os objetivos e finalidades dessas variáveis. Apenas assim será possível entender o currículo inferido nos livros didáticos contemporâneos.

No próximo capítulo serão abordadas as principais variáveis sociais que interagem com o currículo. Essas variáveis, além de se relacionarem com o currículo, também se inter-relacionam e formam um conjunto complexo e de difícil análise. A dificuldade está tanto na compreensão da estrutura complexa quanto na aceitação dos dizeres de APPLE. Estamos tão acostumados a não "enxergar" tais relações que fica difícil ver o mundo com novos olhos.

\footnotetext{
52 Ibid. Pág. 132.

${ }^{53}$ FREIRE, Paulo. Pedagogia do Oprimido. Rio de Janeiro, Ed. Paz e Terra, 2005. Pág. 100.

${ }^{54}$ Ibid.

${ }^{55}$ Texto de Sonia Couto Souza FEITOSA como parte da dissertação de mestrado defendida na FE-USP (1999) intitulada: Método Paulo Freire: princípios e práticas de uma concepção popular de educação
} 
O próximo capítulo tem uma breve introdução às idéias de APPLE e depois é dividido em 4 seções, cada uma abordando uma variável, no caso: o conhecimento legítimo e o livro didático, um currículo nacional e uma avaliação nacional, a escola reprodutora e o livro didático e o comércio do livro didático. Através dessa abordagem, a seguir, será possível ter uma visão mais ampla do currículo, permitindo assim uma análise mais rica dos livros didáticos de eletromagnetismo atuais. 


\section{O Currículo e o Livro Didático}

Para realizar uma análise dos livros didáticos a partir do conceito de currículo de Michael APPLE é necessário estudar não apenas os livros em si, mas também analisar como eles interagem com nossa sociedade. Só através dessas relações é possível entender as razões que levaram o autor de um livro didático a optar por um determinado currículo. Ou seja, o conhecimento apresentado nos livros didáticos possui um conteúdo e uma forma que são moldados de acordo com fatores externos. Esse conhecimento é selecionado previamente pelos que determinam o que vai ser ensinado. Essa seleção, para APPLE, é realizada de acordo com interesses específicos.

Para garantir que esse conhecimento selecionado vá ser utilizado em sala de aula, dispõe-se de processos que forçam a implementação de um determinado currículo. Isso pode ser realizado, por exemplo, através da elaboração de um currículo nacional, seguido de uma avaliação nacional.

Além disso, a escola, através de ações educacionais, pode ajudar nesse processo ao colocar regras e formas de trabalho que colaborem para a formação de um aluno que atenda certas expectativas, como a de um mercado de trabalho.

O livro didático sofre as interações desses agentes e faz parte de um meio que envolve questões financeiras, o comércio de livros, ou seja, depende de um público consumidor, que vai consumir em função da orientação da escola e, em um âmbito maior, do que for estabelecido por um currículo nacional. Logo, o livro, seu conteúdo e forma, resulta de interações de muitos agentes, alguns dos quais apresentados em maior profundidade a seguir. 


\subsection{Conhecimento Legítimo e o Livro Didático}

Assim como o currículo é algo sensível à intervenção de diversos agentes da sociedade, o significado de conhecimento também é algo variável para APPLE. Conhecimento, nesse contexto, acaba sendo uma questão política.

"Para tomar de empréstimo a linguagem de Pierre Bourdieu e Basil Berstein, o "capital cultural" das classes dominantes ou de seus segmentos tem sido considerado o conhecimento mais legítimo. Esse conhecimento e a "habilidade" do indivíduo em lidar com ele constituem um dos mecanismos do complexo processo pelo qual se dá a reprodução cultural das relações de classe, gênero e raça. Deste modo, a escolha de conteúdos particulares e das formas como devem ser abordados na escola está relacionada tanto com as relações de dominação existentes quanto com as lutas para alterar essas relações. " 56

Nessa acepção, ficam indissociáveis a educação, o conhecimento e a cultura de uma sociedade. A escola passa a ser um meio de reprodução cultural, com idéias e valores que garantem o controle de classes dominantes sobre o povo. De acordo com APPLE, esse método é realizado nos Estados Unidos através do livro didático.

"De que maneira esse conhecimento "legítimo" se torna disponível nas escolas? Em geral isso é feito através de algo a que temos dispensado muita pouca atenção - o livro didático. Quer queiramos, quer não, o currículo da maioria das escolas americanas não é definido por cursos de estudo ou por programas sugeridos, mas por um artefato em particular, o texto padronizado e específico para uma

56 BOURDIEU, Pierre e PASSERON, Jean-Claude. Reproduction in Education, Society and Culture .Berverly Hills: Sage, 1977 e BERNSTEIN, Basil. Class, Codes and Control, Vol. 3. Boston e Londres: Rooutledge \& Kegan Paul, 1977. citado em APPLE, Michael W. Trabalho docente e textos: economia política das relações de classe e de gênero em educação; trad. Thomaz Tadeu de Silva, Tina Amado e Vera Maria Moreira. Ed. Artes Médicas, Porto Alegre, 1995, pág. 84 
determinada série escolar, em matemática, leitura, estudos sociais, ciências e assim por diante. "57

A disseminação desse conhecimento "legítimo" é muito forte pois a grande maioria dos estudantes nos Estados Unidos só estudam pelo livro didático.

\begin{abstract}
"O impacto deste fato sobre as relações sociais da sala de aula é imenso. Estima-se, por exemplo, que $75 \%$ do tempo dos estudantes de escolas elementares e secundárias em sala de aula, além de $90 \%$ do tempo dedicado ao estudo em casa, é gasto com materiais apresentados pelos livros didáticos.
\end{abstract}

APPLE indica que infelizmente existem poucos estudos sobre o livro didático dentro dessa visão que envolve os diversos setores da sociedade.

"Entretanto, apesar do caráter ubíquo dos livros didáticos, eles constituem uma das coisas sobre as quais menos sabemos. Embora os textos dominem os currículos nos níveis elementar, secundário e até mesmo superior, muita pouca atenção critica vem sendo dada às fontes ideológicas, políticas e econômicas de sua produção, distribuição e recepção." 59

Tal atenção deve ser dada a isso, pois além de ser o instrumento mais utilizado pelos estudantes, também é o guia orientador de muitos professores. O livro se torna um centro de referência que indica e define o conhecimento a ser ensinado.

\footnotetext{
${ }^{57}$ APPLE, Michael W. Trabalho docente e textos: economia política das relações de classe e de gênero em educação; trad. Thomaz Tadeu de Silva, Tina Amado e Vera Maria Moreira. Ed. Artes Médicas, Porto Alegre, 1995, pág. 85

58 GOLDSTEIN, Paul. Changing the American Schoolbook. Lexington, Massachusetts: D.C. Heath, 1978, p.1. citado em APPLE, Michael W. Trabalho docente e textos: economia política das relações de classe e de gênero em educação; trad. Thomaz Tadeu de Silva, Tina Amado e Vera Maria Moreira. Ed. Artes Médicas, Porto Alegre, 1995, pág. 84

${ }^{59}$ APPLE, Michael W. Trabalho docente e textos: economia política das relações de classe e de gênero em educação; trad. Thomaz Tadeu de Silva, Tina Amado e Vera Maria Moreira. Ed. Artes Médicas, Porto Alegre, 1995, pág. 85
} 
"Uma vez que são os livros didáticos que estabelecem grande parte das condições materiais para o ensino e a aprendizagem nas salas de aula de muitos paises através do mundo e considerando que são os textos destes livros que freqüentemente definem qual é a cultura legitima a ser transmitida..." 60

Para compreender melhor a idéia de cultura legítima, APPLE define dois tipos de cultura: uma que envolve o processo vivido (entendida por Raymond Willians como forma global de vida) e outra como mercadoria. ${ }^{61}$ No primeiro caso, a cultura é entendida como um processo social constitutivo, presente em nossa vida cotidiana. No segundo caso, são focalizados os produtos da cultura, as "coisas" que produzimos e consumimos.

APPLE ressalta que esses dois conceitos se diferenciam apenas no nível analítico, já que grande parte das coisas são na verdade parte de um processo social mais amplo.

"Como Marx levou anos tentando demonstrar, cada produto é expressão de trabalho humano corporificado. Bens e serviços constituem relações entre pessoas - freqüentemente relações de exploração, mas mesmo assim relações humanas. Quando ligamos a luz ao entrar em determinada peça, não estamos usando um objeto, mas também nos envolvendo em uma relação social anônima com o mineiro que trabalhou o fundo da mina para escavar o carvão queimado para produzir a eletricidade. "62

A cultura, ao apresentar essa natureza dual, traz um dilema na compreensão da dinâmica da cultura popular e da cultura de elite. $\mathrm{O}$ estudo de produtos culturais dominantes, como música, televisão, filmes e livros, devem observar o conjunto de

\footnotetext{
${ }^{60}$ APPLE, Michael W. Trabalho docente e textos: economia politica das relações de classe e de gênero em educação; trad. Thomaz Tadeu de Silva, Tina Amado e Vera Maria Moreira. Ed. Artes Médicas, Porto Alegre, 1995, pág. 81

${ }^{61}$ WILLIAMS, Raymond. Marxism and Literature. New York: Oxford University Press, 1977, p. 19

${ }^{62}$ APPLE, Michael W. Trabalho docente e textos: economia política das relações de classe e de gênero em educação; trad. Thomaz Tadeu de Silva, Tina Amado e Vera Maria Moreira. Ed. Artes Médicas, Porto Alegre, 1995, pág. 82
} 
relações por trás de cada uma dessas "coisas" que, por sua vez, fazem parte de uma estrutura maior, de relações sociais e de mercado.

Os livros-texto, no caso, não são simplesmente "sistemas de entrega" de "fatos". 63 Eles são resultado de escolhas condicionadas por atividades políticas, econômicas e culturais. São também elaborados por pessoas reais com interesses reais. E, por fim, são colocados dentro de sistema de mercado, onde os limites de publicação e divulgação são muito importantes. Esses diversos fatores se complementam e se confrontam, dando origem a um produto que é resultado de disputas e conflitos entre as diversas comunidades da sociedade.

No meio da década de 70, no condado Kanawha (Virginia Ocidental, Estados Unidos), por exemplo, houve um caso que mostra como estes conflitos estão presentes em nossa sociedade. Um grupo constituído por pais e mães conservadores, líderes religiosos e empresários fizeram um pequeno protesto questionando o conteúdo e o padrão dos livros didáticos adotados nas escolas locais. Esse protesto se alastrou e o protesto deu lugar a um boicote às escolas, a violência e a uma divisão dos membros da comunidade. Certamente, a escolha dos livros didáticos não foi o único fator que fez com que houvesse esse incidente. As relações entre classes da área rural e da área urbana estavam se tornando cada vez mais tensas e a questão do livro só colaborou para ocorrer um incidente maior. ${ }^{64}$

No Yucaipa, na Califórnia, também aconteceu um caso parecido. Nesse local, que possui pessoas altamente conservadoras e fundamentalistas, começaram a surgir questionamentos quanto às finalidades das escolas e os valores ali transmitidos. $\mathrm{Na}$ situação, pais e membros da sociedade fizeram ataques às escolhas dos livros e ao exercício da autoridade cultural. Acusaram que existia a falta de patriotismo e destruição do conhecimento e autoridade $\operatorname{sagrados}^{65}$.

Em outro caso, nos anos 30, grupos de conservadores, nos Estados Unidos, fizeram uma campanha contra um livro didático. Man in His Changing World, escrito por Harold Rugg e seus colegas, foi considerado pela Associação Nacional de Fabricantes, da Legião Americana, da Federação de Anunciantes e de outros grupos "neutros" como sendo socialista, anti-americano e anti-empresarial. A campanha desses grupos conservadores foi tão grande que os distritos escolares foram forçados a retirar

\footnotetext{
${ }^{63}$ APPLE, Michael W. Conhecimento oficial: a educação democrática numa era conservadora / trad. Maria Isabel Edelweiss Bujes. - Petrópolis, RJ : Vozes, 1997 pag. 74

${ }^{64}$ Ibidem, pág. 76

${ }^{65}$ Ibid
} 
os livros de Rugg das salas de aulas e livrarias. O livro que vendia cerca de 300.000 cópias, em 1938, passou a vender, em 1944, apenas 20.000 cópias aproximadamente. ${ }^{66}$

Esses conflitos, gerados pela adoção de determinados livros didáticos, produzem situações inusitadas que podem ter repercussão internacional. No Japão, por exemplo, um livro didático de história, que recontava de forma mais branda a história da brutal ocupação da China e da Coréia, aprovado pelo governo japonês, estimulou controvérsia ${ }^{67}$.

Recentemente, em abril desse ano, as discussões sobre livros didáticos de história do Japão voltaram a resultar em manifestações. Milhares de chineses se dirigiram ao consulado japonês, em Xangai, para protestar contra a publicação de um livro didático que atenuava as atrocidades cometidas na primeira metade do século $\mathrm{XX}$ pelo Japão. Isso gerou um grande desentendimento entre a China e o Japão, que depois foi atenuado pelos seus dirigentes, pois foram perturbada as relações entre estes paises, que tem amplo e crescente intercâmbio comercial.

Logo, os livros didáticos têm uma importância no contexto escolar e na sociedade. Diz APPLE que:

"Eles, por seu conteúdo e forma, significam construções particulares da realidade, modos particulares de selecionar $e$ organizar um vasto universo de conhecimento possível. Incorporam o que Raymond Williams chamou de tradição seletiva ${ }^{68}$ : uma seleção feita por alguém, com sua particular visão sobre o conhecimento legítimo e a cultura, uma seleção que no processo de privilegiar o capital cultural de um grupo desprivilegia o de outro." ${ }^{69}$.

Essas construções particulares da realidade indicam um pouco sobre o futuro. $\mathrm{O}$ livro-texto, ao selecionar conteúdo e forma, reconhece o que é legitimo e verdadeiro

\footnotetext{
66 SCHIPPER, Miriam. Textbook Controversy: Past and Present, New York University Education Quarterly 14, Primavera/Verão, 1938, p. 31-36. citada em ${ }^{66}$ Apple, Michael W. Conhecimento oficial: a educação democrática numa era conservadora / trad. Maria Isabel Edelweiss Bujes. - Petrópolis, RJ : Vozes, 1997 pág. 78

${ }^{67}$ APPLE, Michael W. Conhecimento oficial: a educação democrática numa era conservadora / trad. Maria Isabel Edelweiss Bujes. - Petrópolis, RJ : Vozes, 1997 pag. 81

${ }^{68}$ WILLIANS, Raymond. The Long Revolution. (London, Chatto and Windus, 1961.

${ }^{69}$ APPLE, Michael W. Conhecimento oficial: a educação democrática numa era conservadora / trad. Maria Isabel Edelweiss Bujes. - Petrópolis, RJ : Vozes, 1997 pag. 77
} 
para a sociedade. Ou seja, o aluno de hoje, que vai ser o cidadão de amanhã, vai estar incorporando determinados valores e significados que serão a base de sua vida no futuro. Tal construção, em larga escala, constrói as futuras relações de nossa sociedade. Ajudam a estabelecer os cânones de verdade e, como tal, a recriar um importante marco de referência sobre os reais propósitos do conhecimento, da cultura, das crenças e da moralidade $^{70}$. Entretanto, mesmo ao aceitar que os textos participam na construção de ideologias e ontologias, vale ressaltar que esses textos foram criados por um grupo específico e não pela sociedade.

O conhecimento oficial, colocado em artefatos curriculares, como os livros didáticos, não existe a partir de um acordo universal, estabelecido por todos os membros da sociedade. Ou seja, através do conteúdo e forma, cada livro transmite um entendimento e significado de um certo conhecimento. No caso da ciência, ela pode ser entendida como um conhecimento muito próximo da matemática, quando o livro é dominado por equações matemáticas, ou pode ser vista como ligada à tecnologia e a utilização prática dos conceitos, se o livro focar apenas a aplicabilidade da ciência, por exemplo. Se existisse um amplo diálogo com a sociedade, seria possível entender e discutir o significado de um determinado conhecimento.

No Survey of High-School Physics Texts ${ }^{71}$, publicado em maio de 1999, nos Estados Unidos, é possível perceber as diferenças entre sete livros didáticos de física que foram analisados. Em alguns casos, como no caso do livro Active Physics, é ressaltada a aplicação do conhecimento na solução dos problemas do dia a dia, enquanto que o Conceptual Physics trata mais de conceitos em vez aplicar muitas fórmulas matemáticas e o Physic- $\mathrm{Al}$ aborda mais as atividades em laboratório. O estudante acaba por compreender a ciência de acordo com a ideologia passada pelo livro. Assim, o significado de ciência, imposto pelo livro, que por sua vez é selecionado por um certo grupo de pessoas, prepondera entre os estudantes.

E, essa ideologia presente no livro didático, não apenas atinge o aluno, mas também interfere nas ações do professor. O professor confia nos livros para organizar as lições e estrutura de conteúdos de uma determinada matéria. O aluno, nesse sistema,

\footnotetext{
${ }^{70}$ INGLIS, Fred. The Managemente of Ignorance: A Political Theory of the Curriculum. New York, Basil Blackwell, 1982, p. 22-23 citado em APPLE, Michael W. Conhecimento oficial: a educação democrática numa era conservadora / trad. Maria Isabel Edelweiss Bujes. - Petrópolis, RJ : Vozes, 1997 pag. 77

71 _. The Physics Teacher. Estados Unidos, American Association of Physics Teachers, vol. $37 \mathrm{n}^{\circ}$

5. Maio, 1999. pág. 283.
} 
atribui uma certa autoridade e importância ao livro, que são considerados corretos e necessários $^{72}$. Sobre esse aspecto, Nilson José MACHADO comenta que:

"O professor abdica do privilegio de projetar os caminhos a serem trilhados, consonância com as circunstâncias - experiência, interesses, perspectivas - de seus alunos, passando a conformar-se, mais ou menos acriticamente, ao encadeamento de temas proposto pelo autor. Tal encadeamento ora tem características idiossincráticas, ora resulta da cristalização de certos percursos, que de tanto serem repetidos, adquirem certa aparência de necessidade lógica; nos dois casos, a passividade do professor torna um pouco mais difícil a já complexa tarefa da construção da autonomia intelectual dos alunos ${ }^{, 73}$.

Por isso, uma reflexão maior deve ser realizada pelo professor em sala de aula. As simples atividades, como ler e escrever, podem estar sendo formas de regulação, exploração e incorporação de uma cultura, escolhida por um determinado grupo que tem certos objetivos, uma cultura dominante. $\mathrm{O}$ ensino deve ser uma ação libertadora para o aluno. Ter a aprendizagem como uma ferramenta que depois será utilizada em um ambiente pré-estabelecido (como, por exemplo, em uma indústria) significa limitar todas as possibilidades que um aluno pode ter. Por essas razões, APPLE defende culturas mais participativas e democráticas nas escolas e fora delas. Afirma que:

“...precisamos dar séria atenção às mudanças no conhecimento oficial, naqueles países que buscam ultrapassar sua herança colonial e elitista. Nesses casos, a política do livro didático é de importância capital, uma vez que representa, muitas vezes, uma tentativa explicita de ajudar a criar uma nova realidade cultural". ${ }^{74}$

\footnotetext{
72 DOWN, A. Graham. Preface, in TYSON, Harriet and-BERNSTEIN, A Conspiracy of Good Intentions: America's Textbooks Fiasco. Washington D.C.: The Council for basic Education, 1988. Pág. 8 citado em APPLE, Michael W. Conhecimento oficial: a educação democrática numa era conservadora / trad. Maria Isabel Edelweiss Bujes. - Petrópolis, RJ : Vozes, 1997 pág. 78

${ }^{73}$ MACHADO, Nilson José. Cidadania e Educação. São Paulo, Escrituras Editora, $4^{\circ}$ Edição, 2002. (Coleção Ensaios Transversais). Pág. 111.

74 APPLE, Michael W. Conhecimento oficial: a educação democrática numa era conservadora / trad. Maria Isabel Edelweiss Bujes. - Petrópolis, RJ : Vozes, 1997 pág. 88
} 
Essa nova realidade cultural só pode ser alcançada através de novos processos de criação de livros, uma nova política cultural, transformação das relações de autoridade e novos modos de ler os livros. Esse objetivo só será alcançado com relações menos reguladoras e mais emancipatórias. É o caso de muitos programas de alfabetização críticos desenvolvidos no mundo, onde as pessoas participam da elaboração dos textos que significam a emergência de seu poder para controlar seus próprios destinos ${ }^{75}$.

Além disso, os alunos têm que ter acesso aos livros didáticos. No Brasil, os livros têm um custo muito elevado e, o aluno mais carente, não consegue adquiri-los. No fim, nas escolas públicas, o único recurso que o professor utiliza é a lousa. E, em alguns casos, o professor acaba por tirar cópias de páginas de livros didáticos ou reescreve o conteúdo dos livros na lousa.

Os professores, nesse sentido, também devem ter acesso ao livro didático. No caso, devem adquirir o conhecimento no livro para depois trabalhar com os alunos. Ou seja, uma modificação na estrutura do livro didático deve ser acompanhada de um programa de formação de professores. Só assim, o professor vai poder lidar de forma adequada com uma nova proposta de livro didático e, conseqüentemente, de currículo.

Ou seja, uma transformação efetiva só vai acontecer se tiver uma ação nos alunos e nos professores. Pois, o então conhecimento "legitimo", já está presente na fala do professor. É preciso uma mudança cultural tanto do docente quanto do discente. No entanto, essas ações, se colocadas, enfrentarão barreiras que tentaram impedir uma mudança significativa.

Essa abordagem, que também trata de ideologia, me faz relembrar a minha ação docente. Por muitas vezes, tratei o conhecimento como sendo legítimo. Ao ver agora os textos de APPLE, percebo que, ingenuamente, passei certos valores e significados para meus alunos. Uma ideologia que hoje percebo que está errada. È interessante e triste notar que nossas ações, mesmo que bem intencionadas, podem estar servindo aos interesses de certas pessoas ou grupos sociais. Ver a realidade não está sendo uma tarefa agradável.

Dando continuidade a esse trabalho, no próximo segmento será abordada mais uma variável que age no currículo, a proposta de um currículo nacional acompanhado de um sistema de avaliação nacional. Será mostrado, a seguir, como uma política nacional, com a primeira "intenção" de garantir um ensino de qualidade para todos,

75 Ibid. 
pode fixar um formato de currículo, forçando alunos e professores a seguirem uma tendência determinada por aqueles que estão no poder. $\mathrm{O}$ controle, tentando assegurar o rendimento e sucesso do currículo, faz com que o docente e o discente não possam contribuir e ter uma postura mais participativa no processo de ensino e aprendizagem. Essa e outras questões serão apresentadas no próximo segmento. 


\subsection{Um Currículo Nacional e uma Avaliação Nacional}

De acordo com APPLE, vem surgindo na educação, nos Estados Unidos, uma série de tendências que vem ganhando cada vez mais impulso. Elas incluem tentativas $\operatorname{para}^{76}$ :

1) reestruturar o trabalho dos(as) professores(as) de modo que ele esteja ligado mais diretamente a resultados de comportamentos específicos e dirigido por técnicas e ideologias gerenciais.

2) especificar e controlar mais estreitamente os objetivos e materiais do currículo para alinhá-los às "necessidades" industriais, militares e ideológicas de um segmento relativamente pequeno, mas poderoso, do público americano.

Unindo essas duas tendências à continua crise financeira na educação americana, temos como resultado um profundo impacto na forma como os professores tem desempenhado seus trabalhos e sobre quais conhecimentos são considerados importantes de serem ensinados. APPLE diz que essas mudanças não estão ocorrendo só nos Estados Unidos.

Nessa complexa estrutura em que a educação se encontra, dois fatores são determinantes: a proposta de um currículo nacional e uma avaliação nacional. $O$ currículo nacional tem como objetivo traçar objetivos comuns de uma nação, enquanto que a avaliação nacional é um meio de verificar se esses objetivos estão sendo alcançados. Logo, esses dois fatores se complementam, alimentando um ao outro, formando um ciclo vicioso com algumas consequiências. Os materiais didáticos, por exemplo, vêm se modificando para atender essa nova situação. Para APPLE, os livros didáticos nos Estados Unidos estão:

“...sendo cada vez mais “orientados por sistemas”. Cada vez se torna mais racionalizado e dirigido por programas de testes e medidas de competência, especialmente no nível elementar; mas com o crescimento da adoção de testes de competência no nível secundário, padronizados em estados inteiros, esta racionalização e padronização

\footnotetext{
${ }^{76}$ APPLE, Michael W. Trabalho docente e textos: economia política das relações de classe e de gênero em educação; trad. Thomaz Tadeu de Silva, Tina Amado e Vera Maria Moreira. Ed. Artes Médicas, Porto Alegre, 1995, pág. 9
} 
estão crescendo também rapidamente nessas áreas. As pressões econômicas e ideológicas sobre os textos são muito intensas. "77

A racionalização e padronização do ensino têm amarrado e limitado a ação do professor, que deve seguir à risca as metas do currículo nacional, tendo assim pouca participação na construção do conhecimento em sala de aula. Os instrumentos de ensino, como o livro didático, também têm sofrido fortes influências desses programas nacionais.

“Embora o livro didático possa ser parcialmente libertador, uma vez que fornece o conhecimento necessário onde faz falta, freqüentemente o texto se torna um aspecto dos sistemas de controle que discuti anteriormente. Pouca coisa é deixada para a decisão do / a professor I a, à medida em que o Estado controla cada vez mais os tipos de conhecimento que devem ser ensinados, os resultados e objetivos desse ensino e a maneira segundo a qual este deve ser conduzido „78

$\mathrm{O}$ aspecto libertador nesse contexto é muito importante. O livro deveria ser um meio de informação para as pessoas. Principalmente hoje, na sociedade atual, onde a comunicação se tornou algo essencial em nosso cotidiano. O controle do Estado sobre a educação tem sido freqüente em vários paises. Na Inglaterra, por exemplo, no governo Thatcher, um currículo nacional foi implantado. Esse currículo indicava o que deveria ser ensinado nas denominadas disciplinas básicas e fundamentais: matemática, tecnologias, ciências, historia, arte, música, educação física e uma língua estrangeira moderna. Para a realização desse projeto foram montados grupos de trabalho que indicaram objetivos padronizados, seguidos de conteúdos a serem abordados e recomendações em sala de aula. E, finalizando todo esse processo, um sistema nacional de avaliação foi aplicado, tentando verificar "o rendimento" e "sucesso" do currículo nacional implantado. ${ }^{79}$

\footnotetext{
${ }^{77}$ APPLE, Michael W. Trabalho docente e textos: economia política das relações de classe e de gênero em educação; trad. Thomaz Tadeu de Silva, Tina Amado e Vera Maria Moreira. Ed. Artes Médicas, Porto Alegre, 1995, pág. 82

${ }_{78}^{78}$ Idem.

${ }^{79}$ APPLE, Michael. Política cultural e educação; trad. De Maria José do Amaral Ferreira. Ed Cortez, São Paulo, 2000, pág. 56
} 
No Brasil, atualmente, existem os Parâmetros Curriculares Nacionais (PCNs), que são uma proposta de currículo nacional, e o Exame Nacional do Ensino Médio (ENEM), que verifica a qualidade da educação do Ensino Médio do país. No entanto, no Brasil, o currículo do Ensino Médio sofre maior influência dos exames para ingresso no ensino superior. E os exames vestibulares, na sua maioria, têm uma proposta curricular contrária aos PCN's e ao ENEM. Diz ZANETIC que dada:

"a alta expectativa de ingressar em algum tipo de curso superior por parte destes alunos, os exames vestibulares acabam tendo uma influência marcante na definição dos currículos das escolas, principalmente naquelas disciplinas consideradas "mais nobres", entre as quais, seguramente, ainda encontra-se a física." 80

Sobre os exames vestibulares, Rubem Alves diz que são "vilões da educação brasileira", pois "escondem, atrás de sua aura de objetividade na seleção dos mais capazes, sua real determinação econômica, pois "os pobres são eliminados antes que a corrida comece ${ }^{, 81}$

A justificativa presente na adoção de um currículo nacional emerge da necessidade de se "elevar os padrões de ensino". Assim seria possível fazer as escolas terem um melhor rendimento. O interessante é que com isso a escola vira o "bode expiatório", já que o resultado vai ser creditado diretamente a ela. Ou seja, toda a responsabilidade pelo ensino está a cargo da escola e o Estado apenas "fiscaliza" se as metas estão sendo alcançadas. ${ }^{82}$

A crítica de APPLE, em relação a esse sistema, recai sobre a falta de participação dos integrantes da escola na elaboração do conhecimento. A cultura comum acaba sendo determinada por poucos. Para APPLE, a cultura comum:

“...não pode ser nunca a extensão geral, a todos, do que uma minoria quer dizer e naquilo que acredita. Em vez disto, e crucialmente, ela

\footnotetext{
${ }^{80}$ ZANETIC, João. Apostila da disciplina Propostas e Projetos de Ensino de Física. IFUSP, 2000. Pág..3.

${ }^{81}$ ALVES, Rubem. Estórias de quem gosta de ensinar. Cortez: Autores Associados, São Paulo, 1984, pág. 81. citado em ZANETIC, João. Apostila da disciplina Propostas e Projetos de Ensino de Física. IFUSP, 2000. Pág..4

${ }^{82}$ APPLE, Michael. Política cultural e educação; trad. De Maria José do Amaral Ferreira. Ed Cortez, São Paulo, 2000, pág. 57
} 
requer não a estipulação dos fatos, conceitos, habilidades e valores que nos tornará todos “alfabetizados culturalmente”, mas a criação das condições para que todas as pessoas participem da criação e da recriação de significados e valores. Ela requer um processo democrático no qual todas as pessoas - não apenas os guardiões intelectuais da "tradição ocidental" - possam ser envolvidas nas deliberações sobre o que é importante." 83

Uma proposta diferenciada que permite uma gestão educacional democrática é o Projeto Político-Pedagógico (PPP). O PPP ultrapassa a mera elaboração de planos burocráticos. Ele busca uma direção e é uma ação intencional, com sentido explícito e um compromisso definido no coletivo escolar. Por isso, o projeto pedagógico de uma escola é por sua vez também um projeto político, pois é construído com os interesses reais e coletivos da população majoritária, mantendo assim um compromisso sóciopolítico.

Para Ilma Passos Alencastro VEIGA este projeto é entendido então como um meio de intervenção pedagógica e política, na medida em que existe uma construção de um certo perfil de curso, cuja compreensão é da interação com a realidade regional e local no qual se desenvolve ${ }^{84}$. Como resultado temos a formação de um cidadão participativo, responsável, compromissado, criativo e crítico. O PPP, para VEIGA, precisa estar sendo estudado, refletido e discutido com a comunidade escolar.

Já o currículo nacional, ao apresentar um pacote fechado de regras inquestionáveis estipulado por uma minoria, descarta as idéias, vontades e anseios daqueles que freqüentam a escola. O ensino, com o argumento de ser uma base para todos, gerando assim uma "igualdade", fica padronizado, uniforme. Trata-se de uma cultura generalista, que descarta a cultura real de cada aluno e impõe outra previamente definida.

“Falando de uma cultura comum, então, não deveríamos nos referir a algo uniforme, algo ao qual temos todos de nos ajustar. Em vez disto, o que deveríamos estar reinvidicando é "precisamente aquele livre,

\footnotetext{
${ }^{83}$ APPLE, Michael. Política cultural e educação; trad. De Maria José do Amaral Ferreira. Ed Cortez, São Paulo, 2000, pág. 76

${ }^{84}$ VEIGA, Ilma Passos Alencastro (org.). Projeto Político-pedagógico da escola: Uma construção possivel. Campinas (SP): Papirus, 1997. pág. 13.
} 
contributivo e comum processo de participação na criação de significados e valores". É o próprio bloqueio deste processo em nossas instituições que deveria estar nos preocupando a todos. “

A escola ideal seria então flexível e se adaptaria às questões, dúvidas e anseios de seus participantes. Como isso não acontece, o aluno acaba tendo um ensino descontextualizado e com conteúdos sem significado.

Alguns educadores defendem que a escola deveria tratar assuntos do cotidiano dos estudantes. Abordando os temas através de exemplos e/ou relações da vida do aluno, os conteúdos teriam mais significado e o estudo seria mais atraente. Sobre essa posição, APPLE diz que:

\begin{abstract}
"Poucas pessoas que tenham testemunhado os níveis de tédio e alienação existentes entre nossos alunos na escola irão discutir a afirmação de que os currículos deveriam estar mais próximos da "vida real”. Esta não é a questão. O que realmente importa é identificar de quem é a visão da vida real que conta." 86
\end{abstract}

Novamente, APPLE remete a educação a uma visão mais geral. Ir ao cotidiano do aluno pode ser uma alternativa interessante, tanto para o aluno quanto para o professor, mas assim perde-se a construção crítica, a discussão de valores e significados. É como vestir a situação como uma outra roupa, você muda o eixo dos temas (para o cotidiano) e continua propagando os interesses de determinados grupos. O trajeto deve ser exatamente o contrário, o aluno é que deve, dentro de um espaço democrático, trazer as suas idéias e discuti-las de forma crítica.

Uma forma de propor um ensino contextualizado, trazendo os elementos do cotidiano do aluno e estimulando uma postura crítica frente a realidade é através dos temas geradores ${ }^{87}$ de FREIRE, pois, nesse método (que foi apresentado no capítulo 4) existe um estudo da realidade do aluno, uma organização do conhecimento voltado aos elementos cotidianos do estudantes e uma aplicação do conhecimento de tal forma que propicie o debate crítico.

\footnotetext{
85 Ibid, pág. 77

${ }^{86}$ APPLE, Michael. Política cultural e educação; trad. De Maria José do Amaral Ferreira. Ed Cortez, São Paulo, 2000, pág. 156

${ }^{87}$ Ibid.
} 
Como exemplo, APPLE cita um currículo de matemática.

"Examinaremos, por exemplo, o currículo de matemática, que coloca como seu próprio centro o objetivo de "alfabetização matemática" para um desempenho flexível no trabalho. A construção da "vida real” aqui - preparação para o trabalho remunerado - é, em geral, totalmente acrítica. Ela põe de lado qualquer preocupação real com as condições concretas sob as quais muitas pessoas trabalham, que vem se degradando" 88

Esse currículo então aborda conteúdos que vão direcionar o aluno para conseguir o emprego, mas não vai discutir questões reais de nossa sociedade, como os baixos salários, os não-sindicalizados, entre outros.

“ Na falta de integração direta de temas como estes no currículo de matemática, não apenas o objetivo de usar matemática para preparar os alunos para a "vida real" se torna uma ficção parcial, mas institucionaliza como conhecimento oficial apenas aquelas perspectivas que beneficiamos grupos que já detêm a maior parte do poder na sociedade." 89

Todos esses pontos levantados podem dar a impressão de que APPLE é contra a existência de um currículo nacional. Na verdade, ele é a favor da real construção do conhecimento por todos. Sobre o assunto, ele cita SMITH, O`DAY e COHEN, que dizem que um currículo nacional só valeria a pena se fosse realizado um amplo debate voltado às questões reais da educação, em vez de buscar apenas instrumentos técnicos de controle da educação.

“A mudança para um currículo nacional só poderia ter sucesso se o trabalho que ela implica fosse concebido e levado a cabo como uma grande e cooperativa aventura de aprendizagem. Tal empreendimento falharia por completo se fosse concebido e organizado basicamente

\footnotetext{
${ }^{88}$ Ibid.

${ }^{89}$ Ibid, pág. 156
} 
como um processo técnico de desenvolvimento de novos exames $e$ materiais e sua conseqüente "disseminação" ou "implementação". 90

E, além disso, seria necessária uma maior comunicação entre os diferentes setores da educação. A formação de professores, por exemplo, deveria estar de alguma forma vinculada a esse processo de elaboração do currículo.

"Um currículo nacional que valha a pena e seja efetivo também exigiria a criação de uma rede social e intelectual nova que permitisse o estabelecimento de conexões. Por exemplo, o conteúdo e a pedagogia da formação de professores teriam de estar ligados muito proximamente ao conteúdo e à pedagogia do currículo das escolas. $O$ conteúdo e a pedagogia dos exames teriam de estar vinculados aos dos currículos e da formação de professores. "91

Assim, o currículo nacional como um processo burocrático e controlador do Estado apenas limita a ação individual e local dos professores. Como conseqüência, outros elementos do cotidiano escolar, como o livro didático, acabam tendo que seguir as regras e idéias propostas pelo currículo nacional. O texto libertador, que traria informação nova ao aluno, termina por ser algo previamente definido, selecionado, ordenado, por um pequeno grupo de pessoas da elite, que tem seus próprios valores e significados acerca do que é educação.

Dentro dos segmentos apresentados desse capítulo, o Currículo Nacional e uma Avaliação Nacional foi o que me pareceu mais real e imediato. Os exames vestibulares estiverem sempre presentes no meu cotidiano e, de certa forma, guiaram minhas docentes. As intenções dos meus alunos eram de ingressar no Ensino Superior e, por isso, minhas aulas seguiam, por muitas vezes, os exercícios de faculdades e universidades de renome. Relembrando, noto que era dada uma grande importância a esses exercícios. Era dado grande crédito ao aluno que conseguisse resolver esses exercícios, como se eles fossem suficientes para validar ou assegurar que o estudante

\footnotetext{
${ }^{90}$ SMITH, Marshall S., O’DAY, Jennifer e COHEN, David K. National Curriculum, American Style: What might it look like? American Educator, 14. (Winter, 1990) pág.10-17, 40-47 citado em APPLE, Michael. Política cultural e educação; trad. De Maria José do Amaral Ferreira. Ed Cortez, São Paulo, 2000 , pág. 58

${ }^{91}$ Ibid, pág. 59.
} 
tivesse aprendido determinado conhecimento. $\mathrm{O}$ conceito de educação então estava relacionado aos exames vestibulares.

Aliás, é com esse conceito limitado de educação que muitas escolas definem seu papel frente à sociedade. Isso resulta em uma estrutura de trabalho muito particular que envolve objetivos e metas a serem alcançadas. As formas de interação da escola frente à sociedade, em particular ao mercado de trabalho, são discutidas na próxima seção. É importante entender, nesse momento, tendo em vista as questões do que é conhecimento "legítimo" e como ações nacionais, como um currículo único seguido de uma avaliação, como é estruturada a escola e como ela se relaciona com esses fatores políticos, econômicos e culturais de nossa sociedade. E, mais do que isso, é preciso compreender como o estudante, o professor, o currículo e o livro didático operam dentro uma instituição que tem uma ideologia pré-definida e imposta.

Cabe então uma pergunta: qual seria o papel da escola? Quais seriam seus objetivos? Que setores da sociedade impõem determinado tipo de ensino, trabalhando assim de forma parecida com a proposta de um currículo nacional? Essas e outras questões são tratadas a seguir. 


\subsection{A Escola Reprodutora e o Livro Didático}

Dando continuidade ao estudo das relações entre currículo, educação e livro didático, APPLE realiza uma análise do palco central do ensino, a escola. Para APPLE, podemos analisar as escolas de duas formas:

“...primeiramente, como uma forma de melhoria $e$ de resolução-de-problemas através das quais ajudamos estudantes particulares a progredir; e, em segundo lugar, numa escala muito mais ampla, detectando quais são os padrões que se formam em relação aos tipos de pessoas que conseguem progredir e quais são os resultados latentes da instituição." 92

Na segunda análise, é possível detectar padrões e resultados sociais que, por sua vez, podem nos dizer sobre o funcionamento oculto do processo de reprodução na escola. A reprodução, nesse caso, trata da transmissão de valores, significados e conhecimento. No entanto, essa reprodução não ocorre diretamente e sem atrito.

"Pois as escolas não são "meramente" instituições de reprodução, instituições em que o conhecimento explícito e implícito ensinado molda os estudantes como seres passivos que estarão aptos $e$ ansiosos para adaptar-se à sociedade injusta." 93

Pelo contrário, o conhecimento transmitido na escola ou é absorvido e reinterpretado por parte dos alunos, ou é aceito de forma parcial, ou ocorre a rejeição dos significados intencionais ou não intencionais da escola. Os alunos não são internalizadores passivos de mensagens sociais pré-definidas.

Ou seja, os alunos reinterpretam e rejeitam o que é considerado como conhecimento legítimo. Os estudantes são ativos construtores de significados que

\footnotetext{
92 APPLE, Michael W. Educação e poder; trad. De Maria Cristina Monteiro. Ed. Artes Médicas, Porto Alegre, 1989, pág. 30

${ }^{93}$ Ibid, pág. 29
} 
enfrentam, não são recipientes vazios no qual o conhecimento é derramado num processo de educação bancária, assim chamada por FREIRE ${ }^{94}$.

Tais características de confronto são importantes para estabelecer um ambiente de análise. A forma de operação das escolas precisa ser observada no conjunto, levando em consideração a reação dos alunos e a intencionalidade e força de agentes externos à educação. Logo, cabe a pergunta:

“Em geral, portanto, se pensarmos as características internas das escolas e o conhecimento encontrado dentro delas como estando intrincadamente conectados a relação de dominação, qual é a implicação do uso desses conceitos para a análise das escolas e do currículo?",95

Essa pergunta foi debatida por APPLE no livro Ideologia e Currículo e foi apresentado o argumento de que os currículos escolares criam e recriam a hegemonia ideológica das classes e das frações de classes dominantes de nossa sociedade. Diz ele que seu trabalho foi orientado pela relação entre poder e cultura. A cultura, no caso, possui uma natureza dual, com a experiência vivida através das interações com certos grupos e com a cultura como mercadoria, denominada por BORDIEU de "capital cultural".

Ao chocar poder e cultura (com esse entendimento), surge uma questão que vai de encontro às funções e objetivos da escola:

"Por que e como aspectos particulares de uma cultura coletiva são representados nas escolas como conhecimento fatual objetivo? Como, concretamente, o conhecimento oficial representa as configurações ideológicas dos interesses dominantes na sociedade? Como as escolas legitimam esses padrões limitados e parciais de conhecimento como verdades inquestionáveis?"96

\footnotetext{
${ }^{94}$ FREIRE, Paulo. Pedagogia do oprimido. Rio de Janeiro: Paz e Terra, 1974. citado em Apple, Michael W. Conhecimento oficial: a educação democrática numa era conservadora / trad. Maria Isabel Edelweiss Bujes. - Petrópolis, RJ : Vozes, 1997 pag. 92

${ }^{95}$ APPLE, Michael W. Educação e poder; trad. De Maria Cristina Monteiro. Ed. Artes Médicas, Porto Alegre, 1989, pág. 32

${ }^{96}$ Ibid, pág. 35
} 
Tais perguntas são fundamentais para entender as relações entre a educação e a sociedade. Ao tratar o conhecimento como sendo algo fechado e incontestável, o aluno com sua cultura deixa de ter espaço para participar na discussão e construção do conhecimento, além de não ter uma visão crítica da situação atual de nossa sociedade. Diz APPLE que:

“..desde Bobbitt e Thorndike até Tyler e, digamos, Popham e Mager, de tentativas de transformar o currículo numa mera preocupação com métodos eficientes, nós tínhamos despolitizado quase totalmente a educação. Nossa busca de uma metodologia neutra e a contínua transformação da área em uma "instrumentação neutra” a serviço de interesses estruturalmente não-neutros servia para nos ocultar o contexto político e econômico de nosso trabalho. "97

Diferente desses autores, APPLE levou em consideração, em sua análise da escola, perspectivas históricas, econômicas, culturais e etnográficas. Tornou-se claro então que existiam três elementos básicos que precisavam ser vistos ${ }^{98}$ :

1) as interações cotidianas e as regularidades do currículo oculto ${ }^{99}$ que tacitamente ensinavam normas e valores importantes;

2) o corpus formal de conhecimento escolar encontrado nos vários materiais e textos e filtrado por intermédio dos professores;

3) as perspectivas fundamentais que os educadores utilizam para planejar, organizar e avaliar o que acontece nas escolas.

Através desses itens foi observado que as práticas cotidianas, tão comuns nas salas de aula, pretendiam a ser menos instrumentos de ajuda no desenvolvimento do

\footnotetext{
${ }^{97}$ APPLE, Michael W. Educação e poder; trad. De Maria Cristina Monteiro. Ed. Artes Médicas, Porto Alegre, 1989, pág. 35

${ }^{98}$ Ibid, pág. 36

99 “... a maioria das análises recentes do currículo oculto podem ser agrupadas em torno de uma teoria da correspondência. De forma esquemática, as teorias da correspondência afirmam que existem características especificas, traços de comportamento, habilidades e disposições que a economia exige de seus trabalhadores. Essas necessidades econômicas são tão poderosas a ponto de "determinar" o que ocorre em outros setores da sociedade, particularmente a escola". - APPLE, Michael W. Educação e poder; trad. De Maria Cristina Monteiro. Ed. Artes Médicas, Porto Alegre, 1989, pág. 36
} 
aluno e mais partes de um complexo processo de reprodução cultural e econômica das relações de classe de nossa sociedade. As escolas não estão organizadas para:

“...ensinar o "conhecimento referente a quê, como e para que”, exigido pela nossa sociedade, mas estão organizadas também de uma forma tal que elas, ao final de contas, auxiliam na produção do conhecimento técnico/administrativo necessário, entre outras coisas, para expandir mercados, controlar a produção, o trabalho e as pessoas, produzir a pesquisa básica e aplicada exigida pela industria e criar necessidades "artificiais" generalizadas entre a população." 100

A forma de trabalho, enraizada na estrutura do capitalismo, acaba sendo um fator importante na escola. Tanto o conhecimento como a forma de lidar e trabalhar esse conhecimento acabam sendo direcionados para as necessidades do mercado de trabalho. Nesse sistema:

“...o tipo de conhecimento considerado como mais legítimo na escola, o qual atua como um complexo filtro para estratificar grupos de alunos, está conectado às necessidades especificas de nosso tipo de formação social."101

Logo, as escolas produzem conhecimento de um tipo particular, direcionado a certos fins. Assim, além de ser um sistema de reprodução, acaba sendo também um sistema de produção, oferecendo um conhecimento que contribue para a formação de um aluno com especificações que atendem um determinado grupo de interesse.

Levando em conta esses aspectos, podemos questionar dois aspectos do conhecimento. Um deles é o conteúdo. Qual o conteúdo que deve ser abordado? E o que não deve ser ensinado? O segundo aspecto a ser verificado é a forma. De que modo o conteúdo, a cultura formal, é reunida? Quais os pressupostos presentes na organização do conhecimento?

${ }^{100}$ APPLE, Michael W. Educação e poder; trad. De Maria Cristina Monteiro. Ed. Artes Médicas, Porto Alegre, 1989, pág. 37

${ }^{101}$ Ibid. 
Nos Estados Unidos, por exemplo, devido a uma série de razões econômicas, políticas e ideológicas, parte dos currículos está organizada em torno da individualização. Os alunos trabalham, de acordo com níveis individuais de destreza, em "folhas de trabalho" individuais pré-especificadas, em tarefas individuais. ${ }^{102}$

Por meio do Kit de Leitura SRA, um dos conjuntos mais usados de leitura, elaborado pela Science Research Associates (uma subsidiaria da IBM), são realizados testes para estabelecer os níveis apropriados de destreza. A partir disso, os alunos são individualmente colocados num nível especifico; e avançam por uma seqüência padronizada de material didático, trabalhando em exercícios de destreza.

Nessa proposta, as atividades pedagógicas, curriculares e avaliativas são planejadas para induzir o aluno a interagir com o professor apenas individualmente e não no coletivo (uns com os outros). Assim, o futuro trabalhador terá uma relação de trabalho individualizada, sem agregar as questões dos colegas de trabalho, que poderiam levar a questionamentos quanto à forma de trabalho, remuneração, entre outros. Esse sistema de ensino acaba acarretando uma formação muito próxima a de outro sistema de ensino, a educação a distância. Nele, temos o máximo da individualização. É impossível desenvolver uma construção coletiva, levando todos os seus preceitos e conseqüências na formação dos estudantes, em um formato de ensino solitário. Essa atitude individualizada se relaciona com a codificação ideológica presente no material didático. APPLE pergunta:

"Como esse material organiza nossas experiências sob formas similares ao processo de consumo individual e passivo de bens e serviços pré-estabelecidos, os quais foram submetidos à lógica da mercantilização, tão necessária para a continua acumulação de capital?" 103

Ou seja, além de existir a preocupação com o conteúdo, é preciso ter uma análise crítica à forma como o conteúdo esta sendo apresentado. A escola exerce uma forte tendência de comportamento em seus alunos ou propor essa ou aquela proposta de

\footnotetext{
${ }^{102}$ APPLE, Michael W. Educação e poder; trad. De Maria Cristina Monteiro. Ed. Artes Médicas, Porto Alegre, 1989, pág. 46

${ }^{103}$ Ibid.
} 
ensino. No mundo capitalista, o ensino está sendo um meio de garantir a permanência de certos valores que alimentam o mercado de trabalho e de consumo.

“Vemos as escolas como um espelho da sociedade, especialmente o currículo oculto das escolas. A "sociedade" precisa de trabalhadores dóceis; as escolas através de suas relações sociais e de seu currículo oculto, garantem de alguma forma a produção de docilidade. Trabalhadores obedientes no mercado de trabalho são espelhados no "mercado de idéias" na escola. ${ }^{104}$

A forma de ensino, que condiciona o aluno a uma forma de trabalho, pode também estar caracterizado em atividades práticas. Com uma falsa prerrogativa que a teoria precisa de uma prática, muitas propostas de ensino são completamente direcionadas, tanto em forma como em conteúdo, para as práticas do futuro trabalho do aluno.

"Comparem isto com a própria avaliação de John Dewey dos perigos de se definir a educação como uma atividade prática estreita supostamente projetada para preparar alguém para o "mundo do trabalho”. Tal educação, centrada em uma definição particular de "prática”, rompe a conexão entre a atividade diária e a compreensão crítica tão necessária em qualquer educação digna deste nome. Assim, quando Dewey defende a educação vocacional (redefinida e para todos), ele a vê como constituída pelo "significado intelectual e social de uma vocação”. “105

A educação vocacional seria uma tentativa de dar abertura para que o aluno, e sua cultura, pudesse estar agindo de forma participativa e crítica. Para isso, Dewey insiste em incluir na educação uma:

\footnotetext{
${ }^{104}$ APPLE, Michael W. Educação e poder; trad. De Maria Cristina Monteiro. Ed. Artes Médicas, Porto Alegre, 1989, pág. 83

${ }^{105}$ APPLE, Michael. Política cultural e educação; trad. De Maria José do Amaral Ferreira. Ed Cortez, São Paulo, 2000, pág. 157
} 
“...instrução sobre o background histórico das condições atuais; formação em ciência que favoreça a inteligência e a iniciativa no lidar com materiais e meios de produção; e o estudo de economia, civismo e política, para colocar o futuro trabalhador em contato com os problemas diários e os vários métodos sugeridos para sua superação" ${ }^{106}$.

A escola então nunca deveria ser um treinamento para as necessidades das indústrias e do mercado. O ensino deveria ter uma visão histórica, ética e política em seus conteúdos e formas. Logo, nessa reflexão, cabem alguns questionamentos:

- Como seria o livro didático com esses objetivos?

- Como seriam publicados e distribuídos esses livros?

- Como a aula seria conduzida com esses objetivos?

- Qual seria a postura da escola frente a essa proposta?

- Como deveria ser a formação dos professores para aplicar essa proposta?

- Como seriam as orientações e direcionamentos nacionais para aplicação dessa proposta em todo o país?

- O livro didático é necessário?

Essas perguntas e o estudo apresentado trazem uma série de questões sobre o livro didático. E, esse capítulo, trouxe uma relação entre o livro didático e uma instituição, no caso a escola. Essa perspectiva, que inicialmente não levei em consideração, traz uma série de consequiências que atingem diretamente o exercício da docência. E, levando em consideração que estamos em uma sociedade capitalista, onde o professor tem que trabalhar para pagar suas contas, a escola se torna uma variável fundamental para a compreensão do currículo e dos livros didáticos.

Para fechar esse capítulo, no próximo segmento será abordada a publicação de livros que, em particular, não foi vislumbrada nas ultimas seções e capítulos. No caso, vão ser tratadas, em detalhe, as editoras, que são as instituições que estão por trás da

\footnotetext{
${ }^{106}$ DEWEY, John Dewey citado em JONES, Ken, Right Turn: The Conservative Revolution in Education .London: Hutchinson, 1989, pág. 104, citado em APPLE, Michael. Política cultural e educação; trad. De Maria José do Amaral Ferreira. Ed Cortez, São Paulo, 2000, pág. 157
} 
elaboração física dos livros, a princípio. $\mathrm{Na}$ seção a seguir é apresentado como as editoras reagem ao mercado de livros, como elas trabalham com os alunos e professores e como ela interage com todos os elementos discutidos até o momento que se relacionam com o currículo e com o livro didático. 


\subsection{Cultura e Comércio do Livro Didático}

Um dos materiais didáticos mais utilizados no ensino é o livro didático. Nele, são apresentados textos que possuem um conteúdo e uma forma. Os textos dos livros didáticos, para APPLE, dominam os currículos em todos os níveis escolares e deve ser analisado de forma ampla.

"A fim de podermos compreender este fenômeno, teremos de situar a produção de materiais curriculares, tais como os livros didáticos, no contexto mais amplo de produção de mercadorias, como é o caso dos livros em geral." 107

Sendo assim, inicialmente temos que identificar quais as condições estruturais principais que servem de base para as publicações de livros didáticos. Nos Estados Unidos são encontradas quatro condições ${ }^{108}$ :

(1) A indústria vende seus produtos - como qualquer outra mercadoria - em um mercado. Mas este mercado, em contraste com a de muitos outros produtos, é inconstante e freqüentemente incerto.

(2) A industria é descentralizada, dividida por grande número de setores cujas operações apresentam pouca semelhança uma com as outras.

(3) Estas operações são caracterizadas por uma mistura de métodos modernos de produção em massa com procedimentos quase artesanais.

(4) A indústria permanece perigosamente equilibrada entre as exigências e restrições do comércio e as responsabilidades $e$ obrigações que lhe cabem como um dos principais guardiões da

\footnotetext{
${ }^{107}$ APPLE, Michael W. Trabalho docente e textos: economia política das relações de classe e de gênero em educação; trad. Thomaz Tadeu de Silva, Tina Amado e Vera Maria Moreira. Ed. Artes Médicas, Porto Alegre, 1995, pág. 85

108 COSER, Lewis, KADUSHIN, Charles e POWELL, Walter, Books: The Culture and Comerce of Publishing. New York: Basic Books, 1982. Pág. 7, citado em APPLE, Michael W. Trabalho docente e textos: economia política das relações de classe e de gênero em educação; trad. Thomaz Tadeu de Silva, Tina Amado e Vera Maria Moreira. Ed. Artes Médicas, Porto Alegre, 1995, pág. 85
} 
cultura simbólica da nação. Embora as tensões entre as exigências do comércio e as da cultura pareçam ter sempre existido, elas vêm-se tornando mais agudas e salientes nos últimos vinte anos.

Além desses fatores, o mercado de livros tem lidado com a diminuição de leitores ao longo dos anos. O artigo Reading at Risk ${ }^{109}$, publicado em junho de 2004 pela National Endowment for the Arts (NEA - Estados Unidos), apresenta um estudo detalhado que mostra que atualmente menos da metade da população adulta lê literatura. Em 1982, 56,9 \% da população adulta dos Estados Unidos lia literatura. Depois, em 1992, houve uma queda, para $54 \%$, e em 2002 , apenas $46,7 \%$ da população adulta dos Estados Unidos lê literatura. De acordo com o artigo, esse declínio é acompanhado por outros meios de leitura impressa. Na análise realizada, são colocadas algumas questões que permeiam o mercado de livros:

1 - Como a leitura impressa compete com a mídia eletrônica?

2 - Como os pais, comunidades, escolas e o sistema educacional trabalha com a literatura e com a questão da diminuição de leitores?

3 - Houve mudanças na escolha de publicações que fizeram algum efeito negativo no mercado de livros?

No Brasil, essa situação se reproduz com números mais estremados. Em 2004, o INEP (Instituto Nacional de Estudos e Pesquisas Educacionais Anísio Teixeira) realizou uma pesquisa $^{110}$ com ingressantes e concluintes do Ensino Superior (escolas públicas e privadas) e constatou que mais de $60 \%$ dos estudantes consultados optam pela televisão como meio de se manter atualizados sobre os acontecimentos do mundo e cerca de $20 \%$ dos graduandos entrevistados não leram nenhum livro em 2004, sendo que apenas $65 \%$ dos entrevistados declararam ter lido em média entre um e cinco livros.

Logo, a produção, distribuição, fabricação e concorrência são fatores muito importantes para as editoras de livros e estão atrelados a um capital financeiro. No caso das editoras, é necessário inicialmente ter um capital para começar a funcionar para depois imprimir os títulos que consigam trazer alguma rentabilidade. A venda, que

\footnotetext{
109 Reading at Risk. Estados Unidos: National Endowment for the Arts. Junho, 2004. www.arts.gov. 15/08/05

${ }^{110} \mathrm{http}: / /$ www.inep.gov.br/informativo/informativo101.htm. 18/08/05
} 
determina a seleção dos títulos que vão ser impressos, está direcionada para se obter o maior lucro possível. Mas a intenção de se obter lucro não é uma exclusividade das editoras. O livreiro e distribuidor também têm interesses financeiros. De acordo com MACHADO, o livreiro ou o distribuidor "abocanham uma parcela expressiva - nunca inferior a cerca de $30 \%$ do preço de capa" ${ }^{111}$. Os direitos autorais, que deveriam receber a maior parcela, já que o livro foi elaborado pelos autores, não recebem nem $10 \%$ do referido preço ${ }^{112}$. Como argumento, FEBVRE e MARTIN, fazem uma análise da história da impressão de livros na Europa e apresentam o seguinte exemplo:

"Há um fato que não pode deixar de ser levado em consideração: tanto impressores quanto livreiros trabalhavam desde o princípio principalmente para obter um lucro. Prova disso é a história da primeira sociedade publicadora, Fust e Schoeffer. Como seus sucessores modernos, os editores do século quinze só financiavam o gênero de livro que julgavam que pudesse vender um número suficiente de exemplares capaz de dar lucro dentro de um prazo razoável.".113

Mas nem todas as editoras estão indo atrás do lucro. COSER, KADUSHIN e POWELL, classificam os editores em dois grupos: as editoras comerciais e as editoras de textos científicos e universitários ou de monografias acadêmicas. Essa divisão se baseia na forma como eles mesmos realizam seu trabalho. Essas classificações:

"Expressam uma variedade de diferenças no que se refere ao tipo de tecnologia que é empregada pela editora, às estruturas burocráticas ou administrativas que coordenam e controlam o trabalho cotidiano da companhia e aos diferentes tipos de riscos e políticas monetárias e de comercialização envolvidas. Por trás da

\footnotetext{
111 MACHADO, Nilson José. Cidadania e Educação. São Paulo: Escrituras Editora, $4^{\circ}$ edição, 2002. (Coleção Ensaios Transversais). Pág. 116.

112 Idem.

${ }^{113}$ FEBVRE, Lucien e MARTIN, Henri-Jean, The Coming of the Book. London: New Left Books, 1976, p. 109, citado em APPLE, Michael W. Trabalho docente e textos: economia política das relações de classe e de gênero em educação; trad. Thomaz Tadeu de Silva, Tina Amado e Vera Maria Moreira. Ed. Artes Médicas, Porto Alegre, 1995, pág. 86
} 
mercadoria, o livro, existe, na verdade, um complexo conjunto de relações humanas." 114

Como MARX disse, "cada produto é expressão de trabalho humano corporificado". O livro, seu resultado após a impressão, expressa também as formas de trabalho de uma editora. Como é a editora que seleciona os títulos que vão ser publicados, a variedade de livros dispostos no mercado reflete as intenções e ideologia das editoras.

"Ao combinar análises dos processos internos de tomada de decisões com análises das relações externas de mercado do mundo editorial, podemos obter uma melhor compreensão da forma como aspectos particulares da cultura popular ou de elite são apresentados em forma impressa e se tornam "aquilo" que é ensinado nas escolas. " 115

No século dezoito, por exemplo, as mulheres da classe média americana alfabetizada, ao dispor de muito tempo para o lazer, se tornaram o público alvo para um determinado gênero literário, o romance. As editoras começaram então a produzir inúmeros títulos de romance que enfatizavam "amor e casamento, individualismo econômico, as complexidades da vida moderna e a possibilidade de manter a moralidade pessoal em um mundo corrupto".

O público e sua demanda, definidos por questões políticas, econômicas e históricas, começaram a ter uma tendência que foi identificada pelas editoras. Essas começaram a agir na vida das pessoas através de textos que discutiam determinados assuntos. No fim, as discussões foram determinadas por fatores da sociedade. O mesmo ocorre com os livros didáticos. O que é ensinado nas escolas, o "conhecimento oficial" dentro de uma disciplina particular, é o resultado de uma complexa conexão entre os diferentes setores da sociedade. Essa conexão visa certamente uma coisa, o lucro. Para COSER, KADISHIN e POWELL, o lucro é motivador das editoras. Diz APPLE que:

\footnotetext{
${ }^{114}$ APPLE, Michael W. Trabalho docente e textos: economia política das relações de classe e de gênero em educação; trad. Thomaz Tadeu de Silva, Tina Amado e Vera Maria Moreira. Ed. Artes Médicas, Porto Alegre, 1995, pág. 87

${ }^{115}$ Ibid.
} 
"Segundo estes autores observam no que se refere à publicação de textos de nível universitário, a ênfase principal está na produção de livros para cursos de nível introdutório, que tem os mais elevados níveis de matrícula. Uma grande atenção é dada à própria concepção do livro e às estratégias de marketing que o levarão a ser utilizados nestes cursos." 116

Ou seja, livros de disciplinas do final do curso não são muito publicados, pois a demanda é pequena e o lucro também o é. Porém, esse fator não é o que decide se um título vai ser ou não publicado.

"Todavia, ao contrário da maior parte dos outros tipos de publicação, os editores de livros-textos não definem seu mercado em termos dos reais leitores de seus livros, mas sim em termos dos/as professores/as." "117

Isso ocorre, pois quem decide o livro que vai ser adotado é o professor, que, por sua vez, tem como objetivo, por exemplo, atingir os objetivos de currículo nacional ou fazer com que os alunos de sua classe passem em uma avaliação nacional.

O estudante, o comprador, tem pouca influência nessa equação, já que não participa da seleção do livro a ser seguido. Na verdade, quem participa mais na elaboração de um livro didático é a editora. Através de "sugestões" e contatos, as editoras impõem tendências aos autores e, com isso, conseguem direcionar o livro para atender a um maior público, obtendo assim maior lucro.

“ Baseados numa avaliação do potencial de vendas e em suas "pesquisas regulares de mercado", uma grande percentagem dos editores de textos universitários realiza uma busca ativa de novos livros. Eles fazem contatos e dão sugestões. Em essência, não seria

\footnotetext{
${ }^{116}$ COSER, Lewis Coser, KADUSHIN, Kadushin e POWELL, Walter, Books: The Culture and Comerce of Publishing. New York: Basic Books, 1982. Pág. 30, citado em APPLE, Michael W. Trabalho docente e textos: economia política das relações de classe e de gênero em educação; trad. Thomaz Tadeu de Silva, Tina Amado e Vera Maria Moreira. Ed. Artes Médicas, Porto Alegre, 1995, pág. 92 ${ }^{117}$ Ibid.
} 
errado dizer que os editores de livros-texto de nível universitário criam seus próprios livros." 118

O ideal para uma editora é ter um livro fixo e definitivo, necessitando apenas de pequenas alterações ao longo dos anos, para não ter que recorrer novamente ao gasto com autores. O resultado é a existência de um livro texto com conteúdo padronizado que pretende atender a todos, mas que no fim não atende ninguém, pois não atinge individualmente cada aluno, ao não levar em consideração a cultura de cada estudante. Talvez, uma forma de promover a cultura de cada estudante, seja trabalhar não apenas com o livro, mas com outras mídias que poderiam completar o livro didático, como a utilização em sala de aula de DVDs interativos, experiências, jornal, livros de literatura, entre outros.

Todos esses fatores são mais reforçados devido a contribuição de um tipo de livro didático: os "textos controlados". Esses livros são redigidos, na maioria das vezes, por escritores profissionais, tendo alguma "orientação" de estudantes de pós-graduação ou professores do ensino superior. Para as editoras, esse tipo de "projeto" é bom, pois fica sob condições estritas de controle de custos, são dirigidos estritamente àquilo que é importante conhecer (no entendimento de seus escritores).

De qualquer forma, para os demais livros didáticos, continuará existindo maior grau de controle centralizado sobre o desenvolvimento e o processo global de instrumentos didáticos publicados para utilização em sala de aula. Para COSER, KADUSHIN e POWELL, tudo isso levará a "uma homogeneização ainda maior dos textos universitários".,"119

Essas questões levantadas nesse capítulo trouxeram novos conhecimentos, pois tratam de uma área que nunca trabalhei diretamente. Fica difícil contestar ou ver relações com minha ação docente, mas no desenrolar do texto é possível compreender como o mercado pode ser bastante cruel e limitador de ações mais criativas e inovadoras. $\mathrm{E}$, os pontos discutidos se relacionam bastante com os outros segmentos desse capítulo. Por fim, a estrutura....não se fecha. Após ler os texto de APPLE fica a sensação de que devem existir outras variáveis que interferem na educação. Talvez isso seja o início de uma postura crítica minha frente às questões abordadas.

\footnotetext{
118 Ibid.

119 Ibid, pág. 93
} 
Tendo em vista essas discussões sobre o comércio do livro didático, a existência de um currículo nacional e de uma avaliação nacional, a identificação do papel da escola e das suas relações com o mercado de trabalho e da compreensão do que se entende por conhecimento legítimo, é possível compreender um pouco melhor o conceito de currículo de APPLE. É através dessas questões apresentadas que a análise dos livros didáticos de eletromagnetismo foi realizada. No entanto, antes de aplicar os conceitos de currículo de APPLE é preciso agora observar o cenário em que o livro está inserido. É necessário identificar os atores que compõem o complexo sistema educacional do qual fazemos parte.

Essa identificação é realizada nos dois próximos capítulos. No primeiro, é tratada a evolução do ensino no Brasil, enfocando o currículo e os livros didáticos. Através desse estudo é possível perceber as razões que levaram a configuração atual do ensino no país. Depois, no capítulo 7, são abordados os principais elementos do sistema educacional brasileiro contemporâneo. 


\section{A Evolução do Currículo e dos Livros Didáticos no Brasil}

Através do conceito de currículo de APPLE, podemos dizer que os livros didáticos, assim como o currículo, tiveram seu desenvolvimento relacionado com questões de natureza política, econômica e cultural. Portanto, para fazer uma análise dos livros contemporâneos de física no Brasil, é importante observar as razões que levaram à criação de um currículo de física e suas modificações ao longo dos anos.

Inicialmente, para averiguar a relevância do papel do ensino, e em particular da física, na formação de um aluno é preciso verificar quais foram os diferentes objetivos da educação. A seguir é apresentado por João Cardoso PALMA Filho, uma seqüência temporal de pensadores de várias datas que pensaram sobre o que é educação:

I) Para os sofistas (Protágoras, Isócrates), a finalidade última da educação é propiciar condições para o desenvolvimento de cidadãos prudentes e eloquentes;

II) Para Sócrates e Platão, educar é desenvolver pessoas que valorizem a verdade acima de qualquer outro valor;

III) Para os escolásticos (Pedro Abelardo e Santo Tomás de Aquino), a educação deve propiciar o desenvolvimento de pessoas capazes de concilar a aprendizagem secular com os valores teológicos;

IV) Para os jesuítas, educar é formar pessoas cultas, capazes de manter valores teológicos católicos ante o desafio intelectual da Reforma;

V) Para Comênio, a educação deve formar as pessoas incorporando os conhecimentos oriundos das novas ciências da natureza;

VI) Para Pestalozzi, educar é desenvolver pessoas capazes de contribuir para a criação de uma nova ordem social;

VII) Para Froebel, educar é formar seres humanos com capacidade de integrar sua existência individual no mundo natural, social e divino;

VIII) Para Herbart, a principal finalidade do processo educativo é desenvolver pessoas com a capacidade de usar de modo flexível o saber intelectual aprendido. $^{120}$

\footnotetext{
${ }^{120}$ PALMA, José Cardoso Filho. Sociedade, educação e Currículo Escolar em O Currículo na Escola Média: Desafios e Perspectivas, Org. PUCCI, Luís Fábio Simões e GUALTIERI, Regina Cândida Ellero
} 
Essa sequiência, que não esgota todos os significados que a educação já teve, mostra como a educação, em sua evolução, possuiu diferentes objetivos. No Brasil, a primeira escola fundada, na Bahia em 1549, tinha como objetivo alfabetizar e doutrinar seminaristas e filhos de nobres do Reino. A partir daí, e por mais duzentos anos, a educação ficou sob a responsabilidade dos padres da Companhia de Jesus, que era totalmente fechada ao estudo das ciências experimentais ${ }^{121}$. O currículo nessa época era focado no ensino de Humanidades. A instrução possuía o ensino da gramática, da retórica e da escolástica, em primeiro plano. No plano superior tinham as letras teológicas e jurídicas, além de alguns rudimentos de Medicina. $\mathrm{O}$ ensino das ciências naturais começou a surgir, timidamente, nas aulas de meteorologia.

Com a expulsão dos jesuítas, em 1759, o Brasil passou por uma destruição de um crescente sistema educacional. Algumas escolas, advindas dos esforços dos carmelitas, beneditinos e franciscanos, tentaram suprir o vazio formado. Por outro lado, em 1775, após a reforma educacional e criação de novos cursos na Universidade de Coimbra, que abriu novos horizontes à cultura nacional e ao estudo das ciências e da observação, fundou-se no Rio de Janeiro a primeira Academia Científica. Mas foi em 1808, com avinda da família real para o Brasil e com a abertura dos portos às nações estrangeiras, que aconteceu a fundação de escola e instituições para aparelhar a Colônia para recepcionar a Corte Portuguesa. O rei D. João VI fundou as primeiras escolas de ensino superior, sendo a Escola de Cirurgia, na Bahia, e a Academia Médica Cirúrgica, no Rio. Ambas possuíam em seus currículos noções de ciências físicas. Porém, essas reformas não foram suficientes para resultar em transformações profundas na mentalidade científica do país.

Depois da proclamação da Independência, e impulsionado pelos ideais da Revolução Francesa, o país começou a ter uma nova orientação na política educacional. Um marco da época foi à fundação em 2 de dezembro de 1837 do Colégio de Pedro II. Seu regulamento, a exemplo dos colégios franceses, tinha estudos simultâneos e seriados, organizado em um período de tempo e organizado em disciplinas (latim, grego, francês, inglês, gramática nacional, retórica, geografia, história, ciências físicas e naturais, matemática, música vocal e desenho). Maior vitória aconteceu na aprovação do

\footnotetext{
. Secretaria da Educação, Coordenadoria de Estudos e Normas Pedagógicas. São Paulo : SE/CENP; Brasília; MEC/SEMTEC/BID, 2004. Pág. 12.

${ }^{121}$ ALMEIDA, João Baptista de Junior. A Evolução do Ensino de Física no Brasil. Revista de Ensino de Física. Vol $1 \mathrm{n}^{\circ}$ 2. Outubro, 1979. Impresso na gráfica do Instituto de Física da USP. Pág. 52.
} 
decreto $\mathrm{n}^{\circ} 8$ de 31 de janeiro de 1838, onde foi guardada a parte da matemática e das ciências físicas aos três anos do secundário, equilibrando assim as disciplinas e rompendo a tradição do ensino exclusivamente humanístico. Contudo:

“...essa implantação estatutária não passou de uma virtual vitória devido às profundas raízes clássicas que ainda amarravam os currículos e aos tramites burocráticos que os estudantes eram obrigados a atravessar para atingirem os estudos superiores. "122

As mínimas aulas de Física, Química e Matemática amontoavam-se nos últimos anos secundários, competindo com as línguas clássicas e modernas, que tinham uma exigência maior para os exames preparatórios para o ingresso nas escolas superiores.

No século XX, começou um intenso desenvolvimento industrial que afetou a relação educação/sociedade. Para João Cardoso PALMA Filho, nesse período, no Brasil, surgem teorias educacionais que centram o papel da educação na formação de mão-de-obra para atender às incipientes necessidades do moderno estado industrial ${ }^{123}$. Devido a essa nova realidade social, três propostas foram colocadas: construção de sistemas educacionais de massa, submissão dos conteúdos curriculares aos objetivos nacionais e renovação dos métodos de ensino. Diz PALMA que a partir desses três pressupostos começou uma renovação educacional que passou por três momentos:

I) 1900-1916: o despertar para a educação, com vistas à universalisação da educação elementar;

II) 1916-1945; a ambição educativa, "época de ambição vertiginosa na qual se formularam ideais; a relação educação e sociedade foi cuidadosamente examinada e a profusão de novas praticas e experiências começou a pôr em marcha amplas e substanciais mudanças dos objetivos, métodos e conteúdos de ensino"

\footnotetext{
${ }^{122}$ HAIDAR, Maria de Lourdes Mariotto, O Ensino Secundário no Império Brasileiro, pág. 20. citado em Revista de Ensino de Física. Vol 1 n 2. Outubro, 1979. Impresso na gráfica do Instituto de Física da USP. Pg. 52.

${ }^{123}$ PALMA, José Cardoso Filho. Sociedade, educação e Currículo Escolar em O Currículo na Escola Média: Desafios e Perspectivas, Org. PUCCI, Luís Fábio Simões e GUALTIERI, Regina Cândida Ellero. Secretaria da Educação, Coordenadoria de Estudos e Normas Pedagógicas. - São Paulo : SE/CENP; Brasília; MEC/SEMTEC/BID, 2004. Pág. 12.
} 
III) 1945-1975: reconstrução e expansão escolares (ampliação das oportunidades educacionais e reformas curriculares voltadas para um melhor ajuste entre o currículo escolar e as novas exigências sociais). ${ }^{124}$

O ensino de Ciências, em particular, teve inicio apenas no século passado, quando começou a ocorrer a introdução do ensino de ciências nas escolas médias. Um dos fatores que favoreceu essa ação foi a criação das Faculdades de Filosofia, como na USP em 1934, que tinha como objetivos centrais a formação de professores para o Ensino Médio e o início da pesquisa científica no Brasil. ${ }^{125}$ A partir desse momento começaram a surgir os questionamentos e primeiras publicações sobre a física na escola secundária. Em 1952, José leite Lopes e Jaime Tiomno escreveram um artigo se posicionando em relação ao papel do livro didático de física. Diziam eles que:

"No caso da física, o livro de texto deve, em cada assunto, começar por descrever os fenômenos mais simples, mostrando sempre que possível como funcionam os fenômenos relativos ao assunto e que são ligados à vida diária; a interpretação física dos mesmos deve ser simples, intuitiva, de modo que os estudantes sintam e visualizem o seu mecanismo; o uso da matemática na fisica não deve, no nível secundário, ser exagerado, sob pena de desviar a atenção do estudantes, que deve estar antes voltada para dominar intuitivamente os fatos físicos da realidade que o envolve". ${ }^{126}$

Esses dois físicos, já naquela época, indicavam uma problemática que ainda hoje está presente nas salas de aula: a necessidade de relacionar o conteúdo com o cotidiano e a ênfase demasiada na linguagem matemática. No trecho abaixo, criticam até a memorização e a influência dos exames sobre os assuntos a serem estudados:

"Infelizmente, a maioria dos livros texto existente em língua portuguesa para o ensino da Física no curso secundário, é altamente

\footnotetext{
124 Ibid. Pág. 13.

${ }^{125}$ LOPES, José Leite. O desenvolvimento da ciência e os povos do terceiro mundo. Revista Paz e Terra, $\mathrm{n}^{\circ} 8$, setembro/ 1968 , pág. 99.

${ }^{126}$ TIOMNO, Jaime e LOPES, José Leite. O ensino da física nos cursos secundários. Ciência e Cultura, vol. V, $\mathrm{n}^{\circ}$ 1, 1952, pág. 45. citado em ZANETIC, João. Apostila da disciplina Propostas e Projetos de Ensino de Física. IFUSP, 2000. Pág..10
} 
insatisfatória. (...) limitam-se os estudantes a memorizar assuntos para exame (..,) não descobrem como é simples o funcionamento de objetos ligados com a vida diária" ${ }^{\prime 27}$.

Além desses dois físicos, cientistas e educadores realizavam inúmeras críticas ao ensino de física no mundo todo. Isso impulsionou um movimento de renovação do ensino de física em 1956, nos Estados Unidos, chamado Physical Science Study Committe (PSSC). Esse movimento começou confeccionando filmes de física e depois desenvolveu textos, guias para professores, aparatos experimentais e filmes didáticos. Em 1957, o PSSC, envolveu uma grande equipe (quase trezentas pessoas) e constituiu o primeiro projeto de ensino de física. Para isso, o PSSC teve grandes verbas do governo americano.

De acordo com ZANETIC ${ }^{128}$, o governo dos Estados Unidos tinha outros interesses no projeto, além dos motivos educacionais. Diz ele que devido ao desenvolvimento tecnológico e cientifico alcançado pela antiga União Soviética, que desencadeou o domínio da tecnologia nuclear e no lançamento do primeiro satélite artificial Sputnik, os Estados Unidos começaram a investir mais em educação, em particular no ensino de ciências.

Logo depois, em 1962, o PSSC foi traduzido para o português e espanhol e implementado no Brasil através do acordo com a Missão Norte-americana de Cooperação Econômica e Técnica do Brasil (USAID). Sobre esse fato histórico Diomar R. S. BITTENCOUT diz que:

"A justificativa pela introdução do PSSC no Brasil, entretanto, não deve ser colocada apenas em termos de sua excelência, mas em um contexto mais geral, em termos do relacionamento cultural, cientifico e educacional entre Brasil e Estados Unidos na medida em que, por exemplo, a tradução brasileira do PSSC contou com colaboração financeira de diversas instituições norte-americanas e

\footnotetext{
127 Ibid.

${ }^{128}$ ZANETIC, João. Apostila da disciplina Propostas e Projetos de Ensino de Física. IFUSP, 2000.
}

Pág.12 
sua primeira edição (de 240.000 exemplares) foi feita pela USAID em prol da Aliança para o Progresso." 129

Esses acordos culturais e educacionais, que atingiam todos os níveis educacionais, cresceram após o golpe militar de 1964 e desencadearam no acordo MECUSAID. Diz ZANETIC que no nível superior, em particular, Rudolf Atcon, assessor norte-americano para assuntos educacionais, elaborou um documento que foi a base para o acordo MEC-USAID e para a reforma universitária no Brasil. Também foi atingida a política de publicação de livros didáticos que começou a ter regras estipuladas pelo acordo MEC-USAID. Esse fato ocorreu em 1967 através de um convênio entre o MEC, o USAID e o Sindicato Nacional de Editores de Livros (SNEL). Sobre isso, a pesquisadora Otaiza ROMANELLI denuncia que:

"Ao MEC e ao SNEL caberiam apenas responsabilidades de execução, mas aos órgãos técnicos da USAID todo o controle, desde os detalhes técnicos de fabricação do livro até os detalhes de maior importância como: elaboração, ilustração, editoração e distribuição de livros, além da orientação das editoras brasileiras no processo e compra de direitos autorais de editores não brasileiros, vale dizer, americanos. "130

Apesar desses fatos, o PSSC foi distribuído no Brasil e, por ser um material muito bem elaborado, teve uma boa aceitação. No Departamento de Física da Faculdade de Filosofia, Ciências e Letras da USP, em 1962, o livro foi até adotado na disciplina "Instrumentação para o ensino de física", ou seja, o projeto PSSC também foi utilizado para formação de professores.

O PSSC contribuiu, para ZANETIC ${ }^{131}$, no incentivo à introdução de atividades experimentais relacionadas ao conteúdo em sala de aula; diminuiu o número de tópicos abordados, dando maior profundidade aos assuntos; apresentou conteúdos organizados

\footnotetext{
${ }^{129}$ BITTENCOURT, Diomar da Rocha Santos. Uma análise do projeto de Ensino de Física - Mecânica. Dissertação de Mestrado, IFUSP e Faculdade de Educação da USP, págs, 5/6

${ }^{130}$ ROMANELLI, O. História da educação no Brasil: 1930-1973. ed Vozes, Petrópolis, 1978, pág 213 citado em ZANETIC, João. Apostila da disciplina Propostas e Projetos de Ensino de Física. IFUSP, 2000. Pág..14

${ }^{131}$ ZANETIC, João. Apostila da disciplina Propostas e Projetos de Ensino de Física. IFUSP, 2000.

Pág.16
} 
para a realização de discussões conceituais; implementou textos de física moderna; trouxe guias para professores que auxiliavam o professor no preparo das aulas; e apresentou diversos tipos de matérias educacionais, como experimentos e filmes, que ofereciam uma visão mais completa da física. O PSSC é, ainda hoje, considerado um dos melhores livros didáticos de física. De acordo com o Survey of High-School Physics Texts, publicado em maio de 1999, "the seven texts reviewed may be categorized as follows. The most sophisticated, in terms of rigor of treatment and accuracy of presentation, is surely PSSC Physics". ${ }^{132}$

Diz ZANETIC que, além da (pouca) utilização nas escolas secundárias, o PSSC teve forte influência no surgimento dos projetos brasileiros. Esse processo aumentou depois do primeiro Simpósio Nacional de Ensino de Física (SNEF), em 1970, que acentuou essa tendência ao aprovar uma moção que estimulava a produção de projetos nacionais de ensino de física.

A partir desse momento começaram a ser desenvolvidos muitos projetos em todo país. Entre eles, ZANETIC destaca o Projeto de Ensino de Física (PEF), Física Auto Instrutivo (FAI) e o Projeto Brasileiro para o Ensino de Física (PBEF). A seguir cada um deles é tratado, a partir de comentários realizados pelos seus autores e/ou protagonistas.

\section{A - Projeto de Ensino de Física (PEF)}

O PEF, desenvolvido na década de 70, possui quatro volumes (sendo que dois são de mecânica, um de eletricidade e outro de eletromagnetismo) e três conjuntos experimentais, contendo instruções de manipulação. De acordo com Jesuína L. A. PACCA $^{133}$, o PEF tem uma metodologia que dá maior ênfase à atividade do aluno, reduzindo assim as aulas expositivas. Essa atividade é realizada através de uma forma diferenciada de leitura, apresentada em seus quatro volumes, e das experiências contidas nos conjuntos experimentais.

Os textos possuem muitas questões entremeadas que deviam ser respondidas pelos alunos em espaços localizados no meio do próprio texto. Diz PACCA, que o

\footnotetext{
5. Maio, 1999. pág. 283

The Physics Teacher. Estados Unidos: American Association of Physics Teachers, vol. $37 \mathrm{n}^{\circ}$

${ }^{133}$ PACCA, Jesuína L. A Análise do Desempenho de Alunos frente a Objetivos do Projeto de Ensino de Física. IFUSP e FEUSP, 1976. Dissertação de Mestrado citada em ZANETIC, João. Apostila da disciplina Propostas e Projetos de Ensino de Física. IFUSP, 2000. Pág. 26.
} 
objetivo dessa forma de texto era de manter os alunos atentos à leitura, ou de apresentar questões diretamente relacionadas às informações passadas anteriormente em sala de aula pelo professor, aplicando assim imediatamente o conteúdo ensinado. Assim, ao responder às questões, o aluno está construindo seu próprio texto, seguindo uma seqüência proposta, e, conseqüentemente, indo a um objetivo determinado. PACCA comenta que a forma do texto "estimula o comportamento de ler e interpretar e a necessidade de conhecimentos de matemática foi reduzida ao mínimo." ${ }^{134}$. Com textos de fácil leitura e com questões colocadas a intervalos curtos, os riscos de respostas erradas se tornam muito pequenos, estimulando assim o estudante. Como conseqüência, o aluno pode sempre dar continuidade às atividades do PEF, já que o estudante não fica com resultados errados.

As atividades encontradas no texto, destinadas aos estudantes, seguem a seguinte estrutura: ler o texto, montar experiências, preencher tabelas com cálculos e dados experimentais, fazer gráficos, debater com os colegas e professor, resolver problemas e responder questões. ${ }^{135}$

O conjunto experimental, além de estar diretamente relacionado com os livros texto, tinha como objetivo gerar situações motivadoras para o aprendizado, oferecendo ao aluno meio de ele mesmo chegar às conclusões que, por sua vez, o levariam a compreender o conteúdo selecionado. A implementação de atividades experimentais ao PEF é uma outra alternativa importante para fazer com que o estudante esteja sempre ativo em sala de aula.

Tanto nos textos quanto nos conjuntos experimentais, o professor tem que deixar de ser apenas um expositor. Como o foco do projeto está na atividade, individual ou em grupo, do aluno, a função do professor muda. Agora, o professor deve esclarecer dúvidas, produzir novos materiais, orientar debates sobre temas importantes e fazer as avaliações dos alunos. No entanto, para que essa metodologia seja aplicável, o programa deve de alguma forma respeitar a evolução do aprendizado de cada aluno. Sobre isso PACCA comenta que o PEF permite, de certa forma, que cada aluno siga seu próprio ritmo, apesar do curso não ser personalizado. No caso, os autores do PEF estabeleceram uma seqüência de tal maneira que a maioria dos alunos consegue atingir os objetivos sem grandes dificuldades e, para os alunos que se adiantam no programa, são apresentados materiais complementares.

\footnotetext{
${ }^{134}$ Ibid.

${ }^{135}$ Ibid.
} 
De acordo com PACCA, os objetivos do PEF eram de: adaptar-se às condições das instituições escolares e dos docentes do $2^{\circ}$ grau do Brasil; apresentar aos alunos alguns fenômenos e conceitos de Física, para que eles pudessem operar esses conceitos, resolver problemas e realizar experiências simples; abordar, de forma prática e teórica, o método cientifico, através do estudo de alguns fenômenos e conceitos específicos da Física; e tratar com os alunos alguns assuntos da Física Contemporânea. ${ }^{136}$

O PEF foi um projeto que trouxe a participação do aluno na criação de seu próprio texto. Essa postura exigida ao aluno é muito interessante, pois assim o conhecimento é construído levando em consideração a cultura do aluno. No entanto, sua estrutura de temas e exercícios ainda era muito parecida com o formato tradicional do livro didático de física. Mesmo abordando alguns tópicos de física moderna, o conteúdo, e sua estrutura, continuaram muito parecidos com os demais livros do mercado.

\section{B - Física Auto Instrutiva (FAI)}

Desenvolvido na década de 70, foi o Física Auto-Instrutiva (FAI), dirigido aos alunos de física do $2^{\circ}$ grau, possui uma estrutura voltada à atividade dos estudantes. Para Fuhad SAAD ${ }^{137}$, nessa proposta o professor deixa de ser um mero transmissor e passa ser um orientador e programador das melhores situações de ensino. O programa conta com instrumentais de laboratório (confeccionados com material de baixo custo para que o programa pudesse ser aplicado em todas as escolas, mesmo aquelas mais desfavorecidas), recursos áudio-visuais e textos históricos e textos auto-instrutivos.

Diz SAAD que: “

“A utilização do Projeto FAI tem como pressuposto situar o aluno e não o professor como centro do sistema, e projetar todos os elementos necessários aos objetivos previstos, para integrarem diretamente o aluno - daí a denominação auto-instrutivo - o aluno é agente de sua própria instrução." 138

\footnotetext{
${ }^{136}$ Ibid. Pág. 27.

${ }^{137}$ SAAD, Saad. Análise do Projeto FAI - Uma proposta de um curso de Física Auto Instrutivo para o $2^{\circ}$ Grau, IFUSP e FEUSP, 1997. Dissertação de Mestrado Citado em ZANETIC, João. Apostila da disciplina Propostas e Projetos de Ensino de Física. IFUSP, 2000. Pág. 31.

${ }^{138}$ Ibid
} 
O FAI tinha como metodologia a aplicação de textos auto-instrutivos lineares que possuíam elementos essenciais para o aprendizado. As matérias eram divididas em pequenas etapas e apresentavam uma ordem crescente de dificuldades. Cada seqüência, que tratava de uma única noção ou fato, era trabalhada intensivamente, através da repetição, até o professor ter certeza que o aluno incorporou determinado conhecimento. Só depois disso o professor avança para uma nova sequiência. Dessa forma, esperava-se que dificilmente ocorressem erros ao longo da aplicação do FAI.

Para SAAD, o FAI tinha como objetivos: propiciar ao professor uma nova metodologia de trabalho e ao aluno uma possibilidade de aprendizagem através de um trabalho realizado (auto-instrução), que podia ser realizado em casa ou na escola; caracterizar o educador como elemento orientador, motivador, criador e avaliador dos resultados provenientes do processo de ensino; confeccionar instrumentos de laboratórios adaptados às nossas condições de ensino (da época); trabalhar com textos históricos, no intuito de oferecer aos estudantes uma visão da forma pela qual a ciência se desenvolve através dos tempos; trabalhar com recursos áudio-visuais.

O FAI tinha uma proposta diferenciada que levava a auto-instrução ao estudante, mas essa proposta não promovia o trabalho em grupo e discussões entre os alunos. Sua estrutura também era muito parecida com a dos livros tradicionais de física e, em nenhum momento, o conhecimento era construído levando em consideração a cultura do aluno.

\section{C - O Projeto Brasileiro para o Ensino de Física (PBEF)}

O Projeto Brasileiro para o Ensino de Física (PBEF) tinha como objetivo maior a apresentação de um modelo de educação cientifica e uma metodologia de ensino, levando em consideração as condições brasileiras, que se desenvolvia dentro de um conteúdo que já era utilizado na época. De acordo com Rodolpho CANIATO ${ }^{139}$, o PBEF propõe um ensino que envolva contato com situações concretas de conteúdo utilizável. Sendo assim, o autor inclui no projeto situações simples, de fácil observação sem instrumentos intermediários caros.

\footnotetext{
${ }^{139}$ CANIATO, Rodolpho. Um projeto brasileiro para o ensino de física. F.F.C.L. de Rio Claro, 1973. Tese de doutoramento. Citado em ZANETIC, João. Apostila da disciplina Propostas e Projetos de Ensino de Física. IFUSP, 2000. Pág. 34.
} 
Os textos e materiais estão divididos em 5 unidades que não possuem uma ordem obrigatória. Com isso, o professor ou o aluno tem a liberdade de escolher qual a ordem a ser estabelecida, atendendo assim às suas necessidades. Uma das unidades denominada "O Céu", que aborda a Astronomia e o desenvolvimento das idéias na ciência de forma histórica, por exemplo, pode ser trabalhada antes ou depois da unidade "Eletricidade", que traz o entendimento básico de circuitos elétricos, desenvolvendo aspectos práticos e operacionais, além de tratar dos fenômenos elétricos.

Diz CANIATO que, diferente da maior parte dos livros didáticos utilizados no Brasil, o PBEF não apresenta uma estrutura de conhecimento colocada em uma série linear. Na estrutura do PBEF, cada unidade é independente, não exigindo assim um prérequisito, que na maioria das vezes força a existência de um conhecimento colocado em série. Logo, o PBEF oferece diferentes alternativas, que possuem suas vantagens e desvantagens. Uma proposta é abordar inicialmente uma unidade que tenha um assunto que mais interesse aos professores e aos alunos. Os assuntos são apresentados por uma leitura que não tem necessidades de pré-requisito, mas coloca uma introdução ao debate de um assunto.

O PBEF tem três níveis de leitura em cada unidade.

1 - "Nível de leitura": é direcionado a todos e traz uma introdução a um assunto. Esse texto tem uma linguagem bem clara e motivadora de discussões.

2 - "Se você quiser saber um pouco mais": é voltado aos alunos que já alcançaram os objetivos do primeiro nível, aprofunda um pouco os temas discutidos no primeiro nível.

3 - "Um pouco mais ainda": traz aspectos ainda mais aprofundados dos assuntos abordados no primeiro nível, utilizando uma linguagem matemática mais exigente.

Ao longo do texto também foram colocadas atividades a serem desenvolvidas pelos alunos. Para CANIATO:

"As atividades devem conter um significado no entendimento de alguma lei fundamental ou estar ligada a alguma idéia importante no campo da física, deve ensejar situações problemáticas em que o educando se defronte com suas próprias perguntas, deve ensejar 
ocasião de uma iniciativa motora em que sejam empregadas as mãos. Além disso, as atividades, mesmo quando ligadas a assuntos aparentemente distantes do cotidiano, devem implicar numa ocasião de alguma ação relacionada com uma tarefa importante em si mesma ou por sua utilização em outra área, deve ensejar oportunidades para debates em que os alunos tenham ocasião de exercitar seus argumentos e os tenham que externar através de uma iniciativa verbal. “140

A partir dessas discussões, o aluno se tornaria um ser ativo, participativo, e o professor acabaria se tornando um orientador que estimula o debate.

Essa característica é também bem presente nas abordagens históricas da ciência. O PBEF procura situar fatos científicos e contexto histórico no intuito do aluno perceber a interação meio-ciência. No capítulo "Assim no Céu como na Terra" é descrita a evolução das idéias que o homem tinha sobre o Universo. Esse capítulo passa desde o surgimento da cultura helênica até o desenvolvimento da ciência moderna. No trecho "Uma grande dupla: Brahe e Kepler", por exemplo, deu-se grande importância à união de forças das atividades teóricas e experimentais da ciência. Diz CANIATO que o PBEF ainda faz uma abordagem histórico-humanista ao trazer aos alunos questões sobre o papel da ciência na sociedade. Discute, por exemplo, os grandes problemas da sociedade moderna, como demanda de energia, de alimentos e poluição.

O PBEF foi uma proposta bem diferente em relação aos livros tradicionais de física. Apresentou uma estrutura de temas diferente, discutia temas históricos e da sociedade e promovia o debate entre os alunos. No entanto, para sua aplicação, o professor deveria ter uma formação bem diferenciada, estando de acordo com a proposta do livro.

O PEF, FAI e PBEF, apesar de terem inúmeras qualidades, deixaram de ser utilizados nas escolas e os livros adotados, para ZANETIC, "eram de qualidade inferior até com relação aos textos utilizados antes da década de sessenta quando o que dominava eram os livros tradicionais". ${ }^{141}$ Para ZANETIC, os motivos para essa situação são:

\footnotetext{
${ }^{140}$ Ibid. Pág. 37.

${ }^{141}$ ZANETIC, João. Apostila da disciplina Propostas e Projetos de Ensino de Física. IFUSP, 2000. Pág..21
} 
(i) os professores, devido aos salários baixos, davam um número exagerado de aulas. Ao se sobrecarregarem, não conseguiam ter um preparo mais cuidadoso das aulas, das lições de casa, e sua criteriosa correção; não conseguiam buscar melhores livros didáticos; e não tinham tempo para se atualizar;

(ii) os exames vestibulares exerciam uma enorme influência nos conteúdos abordados na escola. No fim, o Ensino Médio se transformava em um preparatório para esses exames. Como conseqüência, as escolas, para atender a vontade dos alunos de passarem nos exames vestibulares, acabavam adotando materiais educacionais que seguiam a linha dos vestibulares;

(iii) o livro didático seria assim apenas um produto da industria cultural que fornece lucro aos editores e burocratas. Logo, a edição dos livros didáticos ficaria à mercê do mercado de consumo.

Esses pontos não são apenas a opinião de ZANETIC e não estão apenas centrados nas ultimas décadas. Nas conversas com colegas de trabalho e de pósgraduação, esses pontos são muitos discutidos em relação a situações atuais. Parece que não houve uma evolução em termos educacionais mais amplos, como curriculares, carreira docente, mercado de livros didáticos, entre outros. É triste constatar que pouco mudou.

No próximo capítulo, esses fatores citados serão mais aprofundados e estudados face às questões contemporâneas da educação no Brasil. Também será visto como esses fatores se inter-relacionam e formam tendências no currículo e no livro didático. Retornando aos primeiros capítulos, é possível perceber agora, através dos conceitos de APPLE, como a educação não é neutra, que faz parte de um sistema que envolve a sociedade e seus interesses. Observar esse sistema, agora, se torna algo assustador e instigante, compondo assim um significado de educação muito mais amplo e complexo. Logo, para compreender o currículo inferido no livro didático é preciso identificar quais são os elementos que interferem na educação brasileira e entender como eles operam. 


\section{O Cenário Contemporâneo do Ensino Médio no Brasil}

A educação no Brasil está atualmente baseada na Lei de Diretrizes e Bases (LDB) promulgada em dezembro de 1996. Essa reforma educacional oferece, entre outras coisas, mudanças significativas para estrutura e organização do Ensino Médio que tem crescido expressivamente nos últimos anos. Em 2003, de acordo com o Censo Escolar, o Ensino Médio teve 9,1 milhões de matriculas (valor correspondente a 33\% dos jovens de 15 a 17 anos), sendo que 12,4 \% dessas matriculas foram em escolas privadas $^{142}$. Na tabela abaixo é possível perceber o aumento significativo de matrículas no Ensino Médio nas últimas décadas.

Tabela 1. Evolução da matricula no Ensino Médio, por faixa etária - Brasil, 1970$2000^{143}$

\begin{tabular}{|c|c|c|c|c|}
\hline \multirow{2}{*}{ Ano } & \multirow{2}{*}{ Total } & \multicolumn{3}{|c|}{ Faixa etária (\%) } \\
\cline { 3 - 5 } & & $\begin{array}{c}\text { Menos de 15 } \\
\text { anos }\end{array}$ & 15 a 17 anos & $\begin{array}{c}\text { Mais de 17 } \\
\text { anos }\end{array}$ \\
\hline 1970 & 1.003 .475 & 0,4 & 30,7 & 68,9 \\
\hline 1975 & 1.935 .903 & 1,7 & 34,9 & 63,4 \\
\hline 1980 & 2.819 .182 & 3,5 & 43,0 & 53,5 \\
\hline 1985 & 3.016 .138 & 3,1 & 40,4 & 56,5 \\
\hline 1991 & 3.770 .230 & 3,4 & 43,1 & 53,5 \\
\hline 1996 & 5.739 .077 & 1,7 & 44,0 & 54,3 \\
\hline 2000 & 8.192 .948 & 0,8 & 43,5 & 55,7 \\
\hline
\end{tabular}

Fonte: MEC/Inep/Seec Indicadores de CT\&I em São Paulo - 2001, FAPESP

Antes da atual Lei de Diretrizes e Bases da Educação Nacional (LDB/96), o Brasil passou por diferentes orientações, como a LDB de 1961, a de 1971 e diversos referenciais estaduais como os Guias Curriculares e as Propostas Curriculares do estado de São Paulo.

\footnotetext{
142 Site do MEC. http://www.inep.gov.br/imprensa/noticias/censo/escolar/news04_21.htm. 23/05/05

${ }^{143}$ Site da FAPESP http://www.fapesp.br/indct/tab/tabanex.htm\#2 27/05/05
} 
De acordo com PALMA ${ }^{144}$, A LDB de 1961 (Lei Federal n 4,024) acabou com a centralização curricular existente por força das Leis Orgânicas do Ensino (1942 a 1961). Assim, os estados começaram a ter liberdade para reorganizar o seu currículo. O Estado de São Paulo, por exemplo, mudou a estrutura do Ensino Médio, mudando o antigo Clássico e Cientifico para três grandes áreas do conhecimento: Exatas, Humanas e Biológicas, direcionadas para o vestibular. A LDB foi reformulada em 1971 (Lei 5692/71) preconizando um Ensino Médio de natureza profissionalizante. Isto nunca foi efetivamente implementado nacionalmente, mas houve prejuízos conceituais e práticos tanto ao se tentar aplicar esta lei quanto para tentar contornar sua aplicação.

A Secretaria do Estado da Educação em São Paulo deu início à elaboração dos Guias Curriculares para o Ensino de $1^{\circ}$ e $2^{\circ}$ Graus. Os Guias tinham então como foco os objetivos educacionais, em vez dos conteúdos educacionais, e tinham como referência o paradigma curricular estabelecido em 1949 por TYLER $(1975)^{145}$, que tem enfoque na racionalidade instrumental (técnico-científica).

Quando os Guias foram revistos, dando lugar às Propostas Curriculares, as principais mudanças em relação aos Guias estavam principalmente na aproximação do conteúdo curricular das vivências individuais, valorizando assim o cotidiano do aluno; a interligação entre currículo e sociedade; aplicação da interdisciplinaridade e contextualização dos conteúdos curriculares. Os autores das propostas Curriculares procuravam responder as seguintes questões: que conhecimentos devem o currículo escolar considerar? Que interesses esses conteúdos curriculares contemplam? Como deve o estudante ter acesso a esses conhecimentos? Como organizar os conhecimentos escolares?. Nesse sentido, o texto As Uvas Não estão Mais Verdes: Um novo Currículo?, publicado pela Coordenadoria de Estudos e Normas Pedagógicas em 1986, indica que as Propostas Curriculares vêem o currículo como uma construção social que implica apreciações de natureza política e ideológica. ${ }^{146}$ Logo, o conhecimento não é considerado algo neutro, ou seja, resulta da interação sujeito-objeto, vista numa

\footnotetext{
${ }^{144}$ PALMA, José Cardoso Filho. Sociedade, educação e Currículo Escolar em O Currículo na Escola Média: Desafios e Perspectivas, Org. PUCCI, Luís Fábio Simões e GUALTIERI, Regina Cândida Ellero Secretaria da Educação, Coordenadoria de Estudos e Normas Pedagógicas. - São Paulo : SE/CENP; Brasília; MEC/SEMTEC/BID, 2004. Pág. 14.

${ }_{145}$ DOMINGUES, José Luiz. Interesses humanos e paradigma escolar. Brasília, Revista Brasileira de Estudos Pedagógicos, V. 67, n. 156, p. 351-66,

${ }^{146}$ PALMA, José Cardoso Filho. Sociedade, educação e Currículo Escolar em O Currículo na Escola Média: Desafios e Perspectivas, Org. PUCCI, Luís Fábio Simões e GUALTIERI, Regina Cândida Ellero Secretaria da Educação, Coordenadoria de Estudos e Normas Pedagógicas. - São Paulo : SE/CENP; Brasília; MEC/SEMTEC/BID, 2004. Pág. 17.
} 
perspectiva dialética. Para PALMA: "Alunos e professores são considerados sujeitos reprodutores e transformadores da realidade. Reprodução e transformação são as duas facetas de uma mesma moeda, que garantem ao mesmo tempo a permanência $e$ ruptura." 147

Com âmbito nacional, a Lei que rege a educação brasileira, a LDB 9394/96, apresenta mudanças significativas para a estrutura e organização do Ensino Médio relativamente às anteriores. O Ensino Médio passa a ter uma maior ênfase em uma educação geral como etapa final da educação básica. Essa LDB, de acordo com o artigo 36, também tem as seguintes características, que indicam a busca e qualificação para a cidadania, o trabalho ou o prosseguimento nos estudos:

"I - destacará a educação tecnológica básica, a compreensão do significado da ciência, das letras e das artes; o processo histórico da transformação da sociedade e da cultura; a língua portuguesa como instrumento de comunicação, acesso ao conhecimento e exercício da cidadania;

II - adotará metodologias de ensino e de avaliação que estimulem a iniciativa dos estudantes;

III - será incluída uma língua estrangeira moderna, como disciplina obrigatória, escolhida pela comunidade escolar; e uma segunda, em caráter optativo dentro das disponibilidades da cidadania”.”

Ou seja, o currículo está muito mais voltado à formação do cidadão através da leitura e percepção da evolução histórica da própria sociedade. E essa proposta deve se dar através de uma metodologia onde o aluno participa das atividades, sendo assim um agente ativo dentro da escola. Outro fator importante, observado no terceiro item, é a possibilidade de escolha do currículo pela comunidade escolar.

Os objetivos dessa reforma curricular são ${ }^{148}$ :

I) a formação da pessoa, de maneira a desenvolver valores e competências necessárias à integração de seu projeto individual ao projeto da sociedade em que se situa;

\footnotetext{
147 Ibid.

148 _. Parâmetros Curriculares Nacionais: Ensino Médio / Ministério da Educação,
} Secretaria de Educação Média e Tecnológica. - Brasília : MEC; SEMTEC, 2002. pág. 22. 
II) o aprimoramento do educando como pessoa humana, incluindo a formação ética e o desenvolvimento da autonomia intelectual e do pensamento crítico;

III) a preparação e a orientação básica para a sua integração ao mundo do trabalho, com as competências que garantem seu aprimoramento profissional e permitam acompanhar as mudanças que caracterizam a produção do nosso tempo;

IV) o desenvolvimento das competências para continuar aprendendo, de forma autônoma e crítica, em níveis mais complexos de estudos.

Nessa proposta as disciplinas também são organizadas de forma diferente. Os conteúdos curriculares agora são distribuídos em três grandes áreas do conhecimento: Linguagens, Códigos e suas Tecnologias; Ciências da Natureza, Matemática e suas Tecnologias e Ciências Humanas e suas Tecnologias. Ao tratar os conteúdos dessa forma, a LDB aponta para um tratamento pretensamente interdisciplinar ${ }^{149}$, envolvendo as antigas disciplinas em grupos de conhecimento. Esse tratamento busca, para MARIA Regina KAWAMURA e Yassuko HOSOUME, um conhecimento mais integrado, onde cada área do saber não é considerada como um domínio de conhecimento isolado. Ainda que a disciplina física faça parte da área Ciências da Natureza, "seu ensino deve contemplar as dimensões de linguagem e conteúdo humano-social. Essa é uma das faces da interdisciplinaridade desejada. ${ }^{150}$ Logo, o aprendizado em cada disciplina deve estar, de alguma forma, atento às outras disciplinas e áreas do saber. Porém, alerta KAWAMURA, a interdisciplinaridade não deve ser forçada e sobrepor a própria disciplina de física. Diz que:

\footnotetext{
${ }^{149}$ Interdisciplinaridade é um conceito que surgiu em 6 de maio de 1968 junto às reinvidicações estudantis, ocorridas principalmente na França. Sua idéia fundamental tinha como base uma crítica da fragmentação do conhecimento e suas conseqüências na ruptura que acarretaria na relação entre conhecer e intervir, conhecer e poder. Na linha da fragmentação, se encontrava uma nova organização da Ciência, denominada Big Science, que tinha como objetivo fragmentar um grande problema em pequenas partes, para estudar em particular cada pedaço, de forma isolada, e, depois, reunir os resultados, com objetivos diferentes daqueles com que foram desenvolvidos. De acordo com KAWAMURA, isso ocorreu devido a questões ligadas à corrida armamentista. "A necessidade de se pensar a produção cientifica de uma forma mais integrada levou ao conceito de interdisciplinaridade estendido depois ao cruzamenro de dois saberes para fazer um terceiro, à junção de dois métodos para um novo conhecimento." Esse trecho foi retirado de uma síntese das idéias apresentadas em mesa redonda no V EPEF (Encontro de Pesquisadores em Ensino de Física) e se encontra disponível no site http://www.fae.unicamp.br/ gepce, no texto Disciplinaridade, sim!. 15/09/05.

${ }^{150}$ KAWAMURA, Maria Regina Dubeux e HOSOUME, Yassuko. A Contribuição da Física para um Novo Ensino Médio. Física na Escola, v. 4, $\mathrm{n}^{\circ}$ 2, 2003. Publicado em http://www.sbfisica.org.br/fne/Welcome.shtml. 15/09/05.
} 
"ao invés de ir buscar uma composição forçada com outros saberes, caberia ao ensino de física ensinar a reconhecer o âmbito da própria física, para assim revelar a existência de outros âmbitos, permeados inevitavelmente por valores sociais e visões do mundo que desejamos. E ao tratar de valores, reincorporar a questão da ética, por uma cultura de responsabilidades." 151

Assim, na área Ciências da Natureza, Matemática e suas Tecnologias, que engloba a física, as aulas devem se desenvolver de tal forma que o educando:

"compreenda as ciências como construções humanas, entendendo como elas se desenvolvem por acumulação, continuidade ou ruptura de paradigmas, relacionando o desenvolvimento cientifico com a transformação da sociedade, entender $e$ aplicar métodos $e$ procedimentos próprios das Ciências Naturais; identificar variáveis relevantes e selecionar os procedimentos necessários para produção, análise e interpretação dos resultados de processos ou experimentos científicos ou tecnológicos; apropriar-se dos conhecimentos da Física, da Química e da Biologia, e aplicar esses conhecimentos para explicar o funcionamento do mundo natural, planejar, executar $e$ avaliar ações de intervenção na realidade natural; compreender o caráter aleatório e não-determinístico dos fenômenos naturais e sociais e utilizar instrumentos adequados para medidas, determinação de amostras e cálculo de probabilidades; identificar, analisar e aplicar conhecimentos sobre valores de variáveis, representados em gráficos, diagramas ou expressões algébricas, realizando previsão de tendências, extrapolações e interpolações, e interpretações; analisar qualitativamente dados quantitativos, representados gráfica ou algebricamente, relacionados a contextos socioeconômicos, científicos ou cotidianos; identificar, representar e utilizar o conhecimento geométrico para aperfeiçoamento da leitura, da compreensão e da ação sobre a realidade; entender a relação entre o desenvolvimento

${ }^{151}$ Ibid. 
das Ciências Naturais e o desenvolvimento tecnológico,e associar as diferentes tecnologias aos problemas que se propuseram e propõem solucionar; entender o impacto das tecnologias associadas às Ciências Naturais na sua vida pessoal, nos processos de produção, no desenvolvimento do conhecimento e na vida social; aplicar as tecnologias associadas às Ciências Naturais na escola, no trabalho e em outros contextos relevantes para sua vida; e compreender conceitos, procedimentos e estratégias matemáticas,e aplicá-las a situações diversas no contexto das ciências, da tecnologia e das atividades cotidianas. ${ }^{152}$

Para Luis Carlos de MENEZES, a LDB propõe um aprendizado com contexto, propondo metodologias de ensino que estimulem a iniciativa dos estudantes. Além disso, ressalta que o estudante deve ter "domínio das formas contemporâneas de linguagem (...) para o exercício da cidadania”. ${ }^{153}$ Diz também que a LDB "sinaliza na direção de um aprendizado ativo e participativo, que é a direção oposta ao ensino livresco e ao aprendizado passivo e formal, o que já estabelece marcos para a definição das grandes linhas do currículo". ${ }^{154}$ Nesse sentido, seguindo a LDB, foram desenvolvidos os Parâmetros Curriculares Nacionais para o Ensino Médio, publicado em 1999, que associa o aprendizado a três setores de competência: o da Representação e Comunicação, o da Investigação e Compreensão e o da Contextualização Sociocultural. Esses três permeiam todas as áreas do saber. Ou seja, o contexto sociocultural, que antes era atribuído apenas às áreas das Ciências Humanas, agora também deve ser abordado nas Ciências da Natureza.

MENEZES exemplifica a aplicação de cada um desses setores nas Ciências Naturais $^{155}$ :

152 Parâmetros Curriculares Nacionais: Ensino Médio / Ministério da Educação, Secretaria de Educação Média e Tecnológica. - Brasília : MEC; SEMTEC, 2002. pág. 108.

153 MENEZES, Luis Carlos de. A Ciência como Linguagem em O Currículo na Escola Média: Desafios e Perspectivas, Org. Luís Fábio Simões Pucci e Regina Cândida Ellero Gualtieri. Secretaria da Educação, Coordenadoria de Estudos e Normas Pedagógicas. - São Paulo : SE/CENP; Brasília; MEC/SEMTEC/BID, 2004. Pág. 20.

154 Ibid.

${ }^{155}$ Ibid. Pág. 24. 
- Representação e Comunicação: ler, articular e interpretar símbolos e códigos em diferentes linguagens e representações de sentenças, equações, esquemas, diagramas, tabelas e gráficos, além da elaboração de comunicações orais e escritas, analise e argumentações críticas em relação a temas de cidadania e tecnologia.

- Investigação e Compreensão: selecionar e utilizar instrumentos de medição e cálculo, elaborar hipóteses, interpretar resultados, interpretar e propor modelos explicativos para fenômenos ou sistemas naturais ou tecnológicos.

- Contextualização Sociocultural: reconhecer e avaliar o desenvolvimento tecnológico contemporâneo, suas relações com as ciências, seu papel na vida humana, sua presença no mundo cotidiano e seus impactos na vida social, reconhecer e avaliar o caráter ético do conhecimento científico e tecnológico e utilizar esses conhecimentos para o exercício da cidadania.

Para a Física, em particular, MENEZES cita um exemplo com o tema calor, ambiente e usos de energia. Diz que é possível relacionar esses fenômenos físicos com aspectos geográficos e sociais, como a matriz energética brasileira, ou com a construção civil, abordando o conforto ambiental de edifícios e veículos. No PCN mais, documento publicado em $2002^{156}$, contendo propostas de organização do currículo com base na LDB, muitos exemplos são dados. Primeiramente é apresentada uma nova forma de organização, onde o eixo dos temas a serem abordados é o tema estruturador, que envolve diversos fenômenos físicos e que estão de alguma forma relacionados com a natureza e a relevância contemporânea dos processos e fenômenos físicos, dando enfoque às características mais essenciais que dão base ao saber da Física e propiciam um olhar investigativo sobre o mundo real. No caso de fenômenos elétricos, por exemplo, o tema a ser abordado é denominado "Equipamentos Elétricos e Telecomunicações", e sugere que o professor aborde o tema dentro de quatro unidades temáticas: aparelhos elétricos, motores elétricos, geradores e emissores e receptores. Com isso, de acordo com o PCN mais, espera-se propiciar a possibilidade de identificar e acompanhar o papel desses instrumentos elétricos e dos desenvolvimentos

$156 \_$PCN Mais Ensino Médio: Orientações Educacionais complementares aos Parâmetros Curriculares Nacionais. - Ciências da Natureza, Matemática e suas Tecnologias. Secretaria de Educação Média e Tecnológica. Brasília : MEC ; SEMTEC, 2002. 
tecnológicos associados à sua introdução no mundo produtivo, assim como os efeitos resultantes em meios modernos de telecomunicações.

O Brasil, além de ter essa proposta nacional de currículo para o Ensino Médio, também tem um exame que verifica a qualidade do Ensino Médio brasileiro, o ENEM, Exame Nacional do Ensino Médio, instituído pelo Instituto Nacional de Estudos e Pesquisas Educacionais - INEP, em 1998. Para o MEC, o ENEM serve para que o estudante realize uma auto-avaliação. Também serve para orientar escolhas futuras, tanto no mercado de trabalho quanto na continuidade dos estudos, ingressando no Ensino Superior ${ }^{157}$. O ENEM, que não é obrigatório, pode ser utilizado para seleção para ingresso no Ensino Superior (De acordo com o MEC, mais de 400 instituições de Ensino Superior utilizam o ENEM em seus processos seletivos ${ }^{158}$ ).

O ENEM, é realizado através de uma prova escrita com 63 questões de múltipla escolha e uma redação com um tema de ordem social, cultural ou política. O ENEM analisa as seguintes cinco competências:

I) Dominar a norma culta da língua portuguesa e fazer uso das linguagens matemática, artística e científica.

II) Construir e aplicar conceitos das várias áreas do conhecimento para a compreensão de fenômenos naturais, de processos histórico-geográficos, da produção tecnológica e das manifestações artísticas.

III) Selecionar, organizar, relacionar e interpretar dados e informações, representados de diferentes formas, para a tomada de decisões e enfrentamento de situações-problema.

IV) Relacionar informações, representadas de diferentes formas, e conhecimentos disponíveis em situações concretas, para construir argumentação consistente.

V) Recorrer aos conhecimentos desenvolvidos na escola para elaborar propostas de intervenção solidária na realidade, respeitando-se os valores humanos e considerando-se a diversidade sociocultural.

No entanto, a avaliação que tem definido a forma e conteúdo do currículo do Ensino Médio é o exame vestibular. Diz ZANETIC que:

\footnotetext{
${ }^{157}$ Site do MEC. http://www.mec.gov.br/acs/duvidas/enem.shtm. 30/04/05

158 Ibid.
} 
"Embora nos últimos anos tenhamos testemunhado o advento de outras formas de avaliação, como o Exame Nacional de Ensino Médio (ENEM), se partirmos da hipótese de que, pelo menos na grande maioria de nossas escolas de Ensino Médio, públicas ou particulares, a definição do que passa por conhecimento em física é ditada pela orientação que é fornecida pelos exames vestibulares. "159

Nesse sentido, ZANETIC faz a seguinte pergunta: para que servirá essa "física" escolar" para aqueles cidadãos que não irão continuar seus estudos num curso superior?

De acordo com o Censo da Educação Superior, em 2003, as instituições de Ensino Superior do país tiveram 1.539.859 alunos ingressantes, enquanto que 1,9 milhão de estudantes concluíram o Ensino Médio em 2002. No total foram 3.887.771 matrículas de matrículas no Ensino Superior em 2003, sendo que 70,75\% dessas matrículas foram em instituições particulares. ${ }^{160}$ Logo, uma quantidade razoável de estudantes que não vão ingressar no Ensino Superior acabam por ter um currículo que, para sua vida, não faz sentido, já que não trata de suas necessidades e anseios.

Logo, existe uma realidade que deflagra um conflito entre as tendências dos PCN e do ENEM em relação aos exames vestibulares. No fim, as escolas de Ensino Médio, que são o palco desse conflito, acabam tendo que decidir por uma proposta de currículo e livros didáticos que terão determinados objetivos. Essa cruel realidade impede a liberdade e criatividade dos professores que tentam desenvolver um trabalho diferenciado. Muitas vezes, a pressão exercida pelas escolas e pelos pais de alunos faz com que o professor adote uma tendência educacional colocada pelos exames vestibulares. E, mesmo que o professor consiga vencer essa barreira imposta pelos exames vestibulares, dificilmente vai encontrar materiais didáticos que possuam uma linha educacional com forma e conteúdo diferentes dos exercícios e problemas exigidos no ingresso ao ensino superior.

\footnotetext{
${ }^{159}$ ZANETIC, João. Apostila da disciplina Propostas e Projetos de Ensino de Física. IFUSP, 2000. Pág. 3.

${ }^{160}$ Site do Mec. http://www.inep.gov.br/imprensa/noticias/censo/superior/news04_05.htm. 30/05/05.
} 
Para verificar essa situação é realizada nos próximos capítulos uma análise de alguns livros didáticos de física, no caso, aqueles que tratam de fenômenos eletromagnéticos. Pretendem-se com essa análise observar, através da teoria de currículo de APPLE, o currículo inferido nos livros. 


\section{Os Livros Didáticos, a Educação Contemporânea e a Teoria de Currículo de APPLE}

Desde o início desse trabalho foi desenvolvida uma base teórica que permitiu observar os livros didáticos através de uma nova perspectiva. Essa base foi inicialmente estudada e comparada com outras teorias do currículo, descritas brevemente no capítulo 3. A partir das leituras e aprofundamento dos conceitos discutidos por APPLE, foi possível identificar correlações entre currículo, livros didáticos e campos da sociedade, como política, cultura e economia. Também foi possível perceber com os estudos que, através dessas correlações, certos grupos transmitem uma ideologia que permeia as ações educacionais. Ou seja, determinados significados e valores são transmitidos pelas escolas de tal forma que se obtenha uma determinada formação que, por sua vez, segue os interesses de certos grupos. No caso, para ter o controle da situação, essa ideologia é imposta através de mecanismos que imobilizam uma ação educacional diferenciada e libertadora.

Esses mecanismos, que foram abordados nas seções do capítulo 5, configuram uma rede de ação extremamente complexa e perigosa. A apresentação do conhecimento como sendo algo legítimo, inquestionável e selecionado apenas por certas pessoas, o controle mais amplo do que deve ser ensinado e como deve ser ensinado exercido por um currículo nacional acompanhado de uma avaliação nacional construído sem a participação de alunos e professores, a forma de trabalho realizada nas escolas que indicam uma forte imposição de uma ideologia e a atuação capitalista das editoras e seu desejo em obter lucro com os livros didáticos compõem um quadro complexo que gera uma imobilidade e desesperança no cotidiano escolar.

Ao identificar esse quadro e possuindo o objetivo de analisar os livros didáticos, foi necessário observar o contexto contemporâneo educacional do país no intuito de verificar as correlações e mecanismos discutidos por APPLE. Primeiramente, foi apresentado um levantamento histórico do currículo e dos projetos educacionais de física utilizados no Brasil. Depois, foi vislumbrada a situação atual, passando pelas questões mais urgentes, estatísticas e interventores educacionais, no caso, os PCNs, ENEM e os exames vestibulares.

Nesse sentido, após apresentar todas a base teórica e as questões que permeiam os livros didáticos, é possível realizar uma série de perguntas que podem servir de base 
conceitual para a posterior análise dos livros didáticos. Para entender melhor a idéia de currículo implícito nos livros didáticos é preciso saber:

- Quem definiu o currículo inferido no livro didático?

- Quais são os objetivos que definiram o currículo inferido no livro didático?

- Os objetivos e interesses dos alunos e professores são contemplados, de alguma forma, nos livros didáticos? E como são contemplados?

- Existe abertura nos livros didáticos para a participação dos alunos e dos professores na construção do conhecimento ou o conhecimento é simplesmente apresentado como legítimo e inquestionável?

- O conteúdo e forma nos livros didáticos possuem alguma tendência ideológica perceptível? Qual?

- Os livros didáticos trazem alguma forma de aprendizado que permita uma formação crítica relacionando, por exemplo, a física e a sociedade, em relação à economia, política, cultura, entre outros?

Essas questões de certa forma sintetizam os capítulos anteriores e unem o objetivo de analisar os livros didáticos e a teoria de APPLE. Nos próximos capítulos é realizada a análise de alguns livros de eletromagnetismo do Ensino Médio, tendo em vista as questões formuladas. Para essa análise é apresentada no próximo capítulo uma metodologia que incorpora dez critérios que estruturam as ferramentas para o exercício investigativo. Posteriormente, para cada livro, é apresentada uma conclusão que reúne os critérios investigados e as questões formuladas nesse capítulo. 


\section{Metodologia para Análise dos Livros Didáticos Contemporâneos}

A teoria do currículo de APPLE apresentada nos capítulos 4 e 5 e a verificação de aspectos da realidade educacional brasileira nos capítulos 6 e 7 deverão subsidiar uma análise dos livros didáticos contemporâneos de física para o Ensino Médio.

Para demarcar o âmbito da pesquisa, foram analisados apenas livros que contêm a apresentação de fenômenos elétricos, magnéticos e eletromagnéticos, em torno das quais se fará uma comparação entre os livros escolhidos para análise.

Para essa pesquisa foram analisados livros que possuem, a princípio, propostas de ensino diferentes entre si. O primeiro deles, Curso de Física, apresenta relativa profundidade conceitual e um caráter quase acadêmico. O segundo, Leituras de Física, tem uma abordagem pedagógica mais participativa e ênfase na compreensão dos processos reais. O terceiro, Os Fundamentos da Física, possui uma ementa mais tradicional e também com isso mais difundida que os dois primeiros. Esta diversidade justifica a escolha para melhor ilustrar os currículos implícitos. Assim, com a diferença, foi possível verificar com mais clareza as propostas apresentadas por cada um dos livros. Nessa dissertação foram analisados os seguintes livros ${ }^{161}$ :

1. Curso de Física, vol. 3, $5^{\circ}$ edição ( $1^{\circ}$ impressão). Antônio Máximo e Beatriz Alvarenga. São Paulo: Scipione, 2000

2. Leituras de Física - Eletromagnetismo (5 apostilas). GREF / Grupo de Reelaboração do Ensino de Física

3. Os Fundamentos da Física Vol. 3 - Eletricidade $8^{\text {a }}$ Edição 2003. Ramalho Junior, Francisco

Para realizar a comparação das propostas entre esses livros é necessário estabelecer alguns critérios para análise. A seguir são apresentados os critérios escolhidos que servirão de base para o desenvolvimento dessa dissertação:

1. Descrição geral: esse critério apresenta os dados físicos e de publicação do livro, como a descrição da editora a que pertence, número de exemplares publicados, data da publicação, se apresenta texto direcionado ao professor, $\mathrm{n}^{\circ}$ de páginas que o livro tem, como é a apresentação gráfica, qual o formato

\footnotetext{
${ }^{161}$ Para esse trabalho foi analisada apenas a última edição (edição mais recente) de cada livro.
} 
da página, qual o valor para compra. Nesse critério também é apresentado um breve histórico do autor do livro.

2. Objetivos Explícitos: nesse critério é realizado um levantamento para verificar se o livro apresenta algum objetivo educacional que oriente os textos, tanto em sua forma quanto em conteúdo.

3. Protagonismo Discente: analisar se os autores do livro apresentam uma forma de aplicação do livro que indique a relação do aluno com os constituintes da escola. Sendo assim, pretende-se constatar se, por exemplo, o livro é auto-instrutivo ou se depende da interação com o professor, ou se o livro é só um guia para exercícios ou para leitura fora de sala de aula.

4. Estrutura dos temas: verificação da disposição dos temas abordados, observando se eles apresentam uma ordem definida segundo algum critério.

5. História da física: constatar se o livro tem a presença ou ausência de tópicos da historia da física. E, se tiver, verificar se existe alguma preocupação em mostrar a origem e evolução dos conceitos da física.

6. Cotidiano: verificar se os textos apresentados no livro fazem alguma relação com o cotidiano do aluno de forma crítica, questionando e refletindo sobre a realidade que o cerca.

7. Aulas de experimentos: verificação da presença de textos com experimentos. Se tiver, verificar qual o papel e forma de interação da experimentação nos textos apresentados.

8. Exercícios e problemas: análise dos exercícios e problemas propostos no livro. Verificar onde eles aparecem, se possuem alguma divisão por níveis de aprendizado, se exigem a mera aplicação do temas ensinados ou se exigem algo mais e se podem ser trabalhados individualmente ou em grupo.

9. Interdisciplinaridade: verificação da existência e forma como se desenvolve a correlação entre a física e outros campos de conhecimento.

10. Filosofia da Ciência: verificação da tendência filosófica da ciência passada no texto.

11. Distribuição dos conteúdos em relação aos critérios de análise: apresentação, em uma tabela, que mostra a distribuição dos conteúdos do livro em relação a alguns critérios escolhidos para análise. 
O primeiro critério, "descrição geral", tem como objetivo ter uma idéia geral de como o livro didático é estruturado fisicamente e qual o perfil do autor, que, a principio, foi aquele que selecionou o currículo inferido no livro. O segundo critério, "objetivos explícitos", parte do pressuposto descrito no capítulo 4 dessa dissertação, que diz que o currículo nunca é neutro, mas faz parte de uma tradição seletiva. Nesse critério pretende-se determinar quais são os compromissos fundamentais e valores adotados. Portanto, pretende-se verificar se o autor descreve explicitamente alguma ideologia que permeia e norteia a forma e conteúdo dos livros. Essa orientação pode estar relacionada com o Currículo Nacional, com a Avaliação Nacional, com algum outro método de avaliação, com a cultura e comércio do livro didático, ou com os interesses de determinados grupos (essas relações estão descritas no capítulo 5). Essas relações, no Brasil, foram descritas de forma geral no capítulo 7.

O terceiro critério, "Protagonismo Discente", remete o capítulo 5.3, pois trata da forma de trabalho que pode, ou não, levar um aluno a ter iniciativas e a participar trazendo elementos de seu cotidiano. Ou seja, o planejamento e organização que o livro tem influencia a forma como vai ser desenvolvida a interação professor aluno em sala de aula. O critério "Interdisciplinaridade" também leva em consideração o planejamento e organização dos conteúdos, pois através deles é possível identificar se o livro estimula a interpretação de um objeto de estudo sobre variadas perspectivas que por sua vez se inter-relacionam. E, a interação professor-aluno, pode ter tendências externas, ao impor uma forma de trabalho, que esteja relacionada com uma série de razões econômicas, políticas e econômicas, alimentando assim o mercado de trabalho e de consumo.

Essa questão pode estar também presente na estruturação dos temas a serem abordados. Esse ponto vai ser pesquisado através do quarto critério, estrutura dos temas. Nesse critério, que envolve o capítulo 5.3 e tem exemplos interessantes no capítulo 6, como o PBEF; serão avaliados como estão divididos e subdivididos os temas que, na grande maioria, compõem o índice do livro.

A postura crítica, tanto em relação à ciência quanto à realidade social, que é um dos pontos mais importantes para APPLE, foi avaliado no quinto e sexto critérios, respectivamente, "história da física" e "cotidiano". No capítulo 4 dessa dissertação é descrita a importância da abordagem do desenvolvimento da ciência, pois, a partir dela, é possível ver o conflito interpessoal que culmina e situações educacionais, econômicas e políticas. Isso é fundamental para uma formação mais ativa e questionadora, 
quebrando assim paradigmas tanto da ciência quanto da sociedade. Alias, esse aspecto será abordado também no décimo critério, "Filosofia da Ciência". Já o cotidiano, colocado de forma crítica, é explicitado no capítulo 5.2. Nesse capítulo é colocado como deve ser problematizado o currículo frente às questões da sociedade de tal forma que o aluno, através de discussões e participação ativa, tenha uma postura critica em relação a sua própria realidade.

O critério "As aulas de experimento" está de certa forma relacionado com a história da ciência e a forma de trabalho. Ou seja, através do método de pesquisa dos fenômenos e da percepção de ciência o estudante pode, ou não, incorporar valores de uma ciência que não tem nada a ver com a real ciência desenvolvida ao longo da história. Com esse critério, que se relaciona com o critério "Filosofia da Ciência", é possível perceber se os livros propõem que o experimento é só uma constatação da teoria ou se a teoria é construída através da experiência ou se teoria e experiência estão distantes dos fatores relacionados ao desenvolvimento histórico e social da física. Portanto, nesse tema, pretende-se verificar se as aulas de experimento estão sendo usadas apenas para memorização mecânica e simples constatação de leis físicas, ou se está motivando e incentivando a reflexão e debate crítico dos fenômenos físicos.

Tal memorização e simples constatação das leis físicas também serão avaliadas no oitavo e último critério denominado "exercícios e problemas". Como visto no capítulo 5.3, os exercícios podem levar o aluno a incorporar um sistema de trabalho hierárquico e de obediência ao chefe, que no caso escolar é o professor, que pode ou não legitimar certos valores ao aplicar avaliações que cobram a incorporação dos mesmos. Esses exercícios e problemas também podem estar relacionados a um currículo nacional, uma avaliação nacional ou algum outro tipo de avaliação. Portanto, o treino dos conceitos ensinados aos alunos passa a ser um guia de aprendizado para certos valores que foram definidos por determinados grupos.

Os critérios descritos acima muitas vezes se encontram e se complementam. Assim, reunidos, compõem uma ferramenta para a investigação dos livros e para a solução das questões a respeito dos livros didáticos, formuladas no capítulo anterior.

Após analisar os textos com base em todos esses critérios é realizada uma pequena conclusão específica a cada livro. Depois, é realizada uma conclusão geral envolvendo todos os livros. 


\subsection{Análise do Livro "Curso de Física”, vol. 3 (autores: Antônio Máximo e Beatriz Alvarenga)}

Descrição geral: O livro "Curso de Física” foi elaborado por Antônio Máximo e Beatriz Alvarenga e sua $5^{\circ}$ edição ( $1^{\circ}$ impressão) foi publicada em 2000 pela editora Scipione. O "Curso de Física" possui um livro direcionado para o estudante e outro voltado para o professor. O do estudante tem 432 páginas, é colorido, tem dimensão de 19,5 cm por $26 \mathrm{~cm}$, é impresso em papel couche brilhante, é distribuído para todo o país e tem preço de capa de 67,20 reais ${ }^{162}$. O livro do professor tem 132 páginas, é preto e branco, tem $19 \mathrm{~cm}$ por $26 \mathrm{~cm}$ e é impresso em papel comum.

O livro do professor possui, inicialmente, um prefácio, que aponta algumas questões sobre o ensino de física, e duas sugestões de planejamento (aula a aula), sendo que a primeira é para o caso de um curso de 2 anos com carga horária de 2 horas-aula por semana (72 aulas no ano letivo) e a segunda é para um curso de 3 anos com 3 horasaulas por semana (108 aulas no ano letivo). Depois é realizada uma abordagem em cada capítulo do livro para o estudante. Essa abordagem é dividida em duas partes: a primeira tem um breve texto (quase uma página) com algumas sugestões, recomendações e uma explicação das razões que levaram os autores a escolher determinado conteúdo em vez de outro, e na segunda tem a resolução, passo a passo, dos exercícios propostos no livro do estudante.

Antônio Máximo Ribeiro da $\mathrm{Luz}^{163}$ é licenciado e bacharel em Física pela Universidade Federal de Minas Gerais (UFMG) e cursou o Harvard Project Physics (HPP), pela Universidade de São Paulo (USP). Autor de diversos livros, dos quais muitos já foram distribuídos em paises da América Latina, Antônio Máximo sempre se dedicou ao estudo e ensino de Física. Atualmente, é professor adjunto do Departamento de Física da Universidade Federal de Minas Gerais.

\footnotetext{
${ }^{162}$ Valor obtido na editora no dia 1 de março de 2005. 0800-161700.

${ }^{163}$ Informações obtidas nos sites http://www.scipione.com.br/catalogodidatico/detalhesdidaticos.asp?c=37\&o=4903-7. e http://www.revistaencontro.com.br/dezembro03/especial/educacao.asp. Ambos consultado em 13 de setembro de 2005.
} 
Beatriz Alvarenga Álvarez ${ }^{164}$ é formada em engenharia civil, em 1946, pela Escola de Engenharia da Universidade Federal de Minas Gerais (UFMG) e começou, em 1949, a lecionar disciplinas relacionas a física. Beatriz fez vários cursos de pósgraduação, inclusive doutorado. Por muitos anos, exerceu o magistério lecionando física e matemática em vários colégios de Belo Horizonte. A partir de 1968, passou a trabalhar integralmente no curso de Ciências Exatas da UFMG. Em 1988 obteve o titulo de professora emérita no Instituto de Ciências Exatas da UFMG (ICEx). Na Sociedade Brasileira de Física (SBF), atuou como vice-presidente, membro do Conselho Diretor e secretária de ensino. Nesse cargo, coordenou o $2^{\circ}$ Simpósio Nacional de Ensino de Física (SNEF), realizado em Belo Horizonte.

Objetivos Explícitos: Na seção “Ao professor”, no livro para o estudante ${ }^{165}$, os autores comentam que a educação no país tem passado por modificações. Dizem eles que, a partir do diálogo com vários professores e escolas e através de levantamentos estatísticos, foi notado que essas modificações, em alguns aspectos, dificultam o trabalho do professor e o aprendizado dos alunos. A grande diversidade de temas, por exemplo, leva o professor a ter que enfrentar conteúdos muito diversos. E, nessas circunstâncias, "a escolha de um livro-texto que se adapte a estas diversificações tornase muito difícil"166.

Mesmo tendo ciência dessas dificuldades, os autores propõem em seu livro um ensino que leve os conceitos fundamentais da física a todos os estudantes. E, no texto dessa seção, é frisado que a física deve ser levada também aos alunos que não vão seguir uma profissão que envolva essa ciência. Comentam que a física é importante para todos, pois ela permeia o dia-a-dia de qualquer cidadão. Tendo esses aspectos, são citadas algumas características do livro ${ }^{167}$ :

- Foi apresentado, em cada tópico, para incentivar o aluno, uma abordagem dos conceitos da física presente no cotidiano do aluno.

\footnotetext{
164 Ibid.

165 MÁXIMO, Antônio e ALVARENGA, Beatriz. Curso de Física, vol. 3, $5^{\circ}$ edição. São Paulo: Scipione, 2000. pág. 8

166 Ibid.

${ }^{167}$ Nessa parte são apresentadas as intenções do autor. A análise mais profunda é realizada nos próximos critérios.
} 
- Para não entediar o aluno, foi dado maior enfoque às leis gerais, diminuindo assim as informações de caráter especifico. Isso também possibilitou a utilização de uma linguagem mais simples.

- Os textos de cada seção foram divididos em pequenos blocos, procurando com isso amenizar a leitura.

- Para solidificar as idéias básicas desenvolvidas pelo professor, em quase todas as seções, foram apresentados exemplos de exercícios resolvidos.

- O livro possui muitos exercícios divididos em diversos níveis, como exercícios de revisão, problemas, testes e questões de vestibular. Pretende-se com isso oferecer ao professor diversas formas de abordagem, que podem ser moldadas de acordo com a realidade da escola.

- No fím de cada capítulo aparece o "Tópico Especial” que é um texto histórico ou relacionado a aspectos modernos das aplicações da física.. "Este tipo de leitura é geralmente agradável ao estudante, pelo interesse que os assuntos despertam, por sua linguagem simples e por ser facilmente compreendida ${ }^{168,}$.

- Levando em consideração a ausência de laboratórios e aparelhos adequados para experiências foram propostas experiências simples com a utilização de material de uso diário do estudante.

No final da seção "Ao professor”, os autores afirmam que o professor deve selecionar os temas do livro de acordo com a duração e natureza do curso que vai ser realizado. Esses fatores estão ligados à realidade da escola e ao público que ela atende.

Protagonismo Discente: Na seção "Como usar o Curso de Física"169, os autores indicam um método de aprendizagem direcionado apenas ao aluno. Dizem que é interessante que o aluno realize inicialmente e de forma individual a leitura da seção que será abordada pelo professor. Se houver dúvida, é recomendado que o estudante procure o professor ou os colegas. Os autores ressaltam que o aluno não deve fazer uma leitura para memorizar eventuais fórmulas, pelo contrário, indicam que é importante a compreensão do texto e dos conceitos.

\footnotetext{
${ }^{168}$ MÁXIMO, Antônio e ALVARENGA, Beatriz. Curso de Física, vol. 3, 5 edição. São Paulo: Scipione, 2000. Pág. 9

${ }^{169}$ Ibid. pág. 11.
} 
Após a leitura, é recomendado que se faça a resolução dos Exercícios de Fixação, que são mais simples e servem para sedimentar o conhecimento previamente lido. A facilidade, no caso, serve como forma de incentivo para que o aluno continue o estudo. Na seqüência, o aluno pode ir para os exercícios mais difíceis à medida que vai conseguindo solucionar os problemas.

O “Tópico Especial”, com o subtítulo "para aprender um pouco mais", é indicado uma leitura suplementar, que possui um texto fácil e sem contas, e que relaciona a física a eventos históricos e a aplicações tecnológicas.

A "Revisão", localizada no final do capítulo, é composta por uma série de perguntas que resume os conceitos abordados no capítulo. Com as perguntas respondidas, o estudante tem em mãos um guia que pode servir para futuramente recapitular os conhecimentos aprendidos.

Por fim, para facilitar a compreensão e a aprendizagem dos conteúdos, são apresentadas propostas de experiências. Essas experiências, de acordo com a seção "Como usar o Curso de Física", devem ser discutidas entre os alunos e professor, permitindo assim uma visão mais clara dos fenômenos estudados.

As atividades sugeridas no livro, para os autores, podem ser desenvolvidas individualmente, em grupo, em classe ou em casa.

Estrutura dos temas: o livro Curso de Física apresenta uma estruturação de temas que está organizada através de fenômenos físicos. São três unidades compondo, ao total, oito temas:

\section{Campo e Potencial elétrico}

Carga elétrica

Campo Elétrico

Potencial Elétrico

\section{Circuitos Elétricos de Corrente Continua}

Corrente Elétrica

Força Eletromotriz - Equação do Circuito

\section{Eletromagnetismo}

Campo Magnético 
Indução Eletromagnética - Ondas Eletromagnéticas

A Nova Física

Os autores dizem, sobre essa divisão, que "acreditamos que esta seja a maneira mais natural de apresentar estes conceitos e julgamos que a tentativa feita por alguns autores de iniciar o estudo da Eletricidade pelo conceito de corrente elétrica é

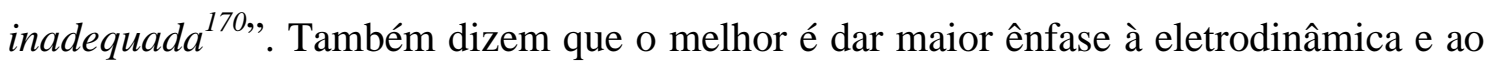
eletromagnetismo, pois esses temas apresentam um grande número de aplicações ligados ao cotidiano do aluno.

Dentro dessa estrutura, para os autores, os fenômenos e conceitos a serem estudados foram selecionados de acordo com sua proximidade com a vida diária dos estudantes. O intuito é mostrar ao aluno que aquilo que é estudado nas aulas de física é encontrado, na maioria das vezes, em seu cotidiano. ${ }^{171}$

A estrutura proposta pelos autores, no entanto, não se parecem com as propostas dos PCN. Em exemplos mostrados no PCN mais é possível perceber uma estrutura bem diferente em relação à apresentada pelo livro Curso de Física. No PCN é indicado, para o eletromagnetismo, que o currículo deve ser montado de tal forma que possibilite a identificação e acompanhamento do papel dos instrumentos elétricos e dos desenvolvimentos tecnológicos associados à sua introdução na sociedade e suas consequiências. Para fenômenos elétricos é sugerido, por exemplo, que o professor aborde o tema em quatro unidades temáticas (aparelhos elétricos, motores elétricos, geradores e emissores e receptores) compondo assim a unidade "Equipamentos Elétricos e Telecomunicações".

A estrutura do livro Curso de Física apresenta uma ordem fenomenológica, passando do estudo da carga em repouso (eletrostática) para a carga em movimento (eletrodinâmica). Com os temas organizados dessa forma, que se assemelham muito ao rol de requisitos apresentados nos manuais de inscrição dos exames vestibulares, não é possível identificar prontamente os instrumentos elétricos e a relação entre a física e a realidade do aluno.

\footnotetext{
${ }^{170}$ MÁXIMO, Antônio e ALVARENGA, Beatriz. Curso de Física - Manual do Professor, vol. 3, $5^{\circ}$ edição. São Paulo: Scipione, 2000. pág. 14.

${ }^{171}$ Ibid. Pág. 5 item 7.
} 
História da física: os aspectos históricos da física são apresentados de três formas: em pequenas biografias espalhadas ao longo do livro, na seção denominada “Tópico Especial" e no último capítulo intitulado "Nova Física”.. As biografias aparecem no meio texto de cada capítulo, estando relacionadas com o conteúdo ali apresentado, e são destacadas com um quadro de cor diferente ao do fundo da página. $\mathrm{O}$ texto da biografia contém o nome completo e foto ou desenho do cientista ou filósofo, data da nascimento e morte, e um parágrafo que descreve brevemente sua trajetória e contribuição para a física. Sobre o cientista Charles Augustin de Coulomb é dito que:

"Nasceu em Angoulême, na França, e é conhecido principalmente pela formulação da lei que traz seu nome. Como engenheiro militar, Coulomb trabalhou durante nove anos na Índia. Retornando à França, dedicou-se às pesquisas cientificas, tendo inventado a balança de Coloumb, dispositivo que lhe permitiu medir as forças elétricas com enorme precisão, levando-o a estabelecer sua célebre lei. Coulomb desenvolveu pesquisas também em outros campos: sobre o atrito das máquinas, elasticidade dos metais, fibras de seda etc. A unidade de carga elétrica no Sistemas Internacional recebeu o nome de Coulomb em sua homenagem." 172

Ao longo do livro são apresentadas as biografias de Thales de Mileto, William Gilbert, Benjamim Franklin, Charles Augustin de Coulomb, Michael Faraday, Alessandro Volta, Robert J. van de Graaff, Robert Andrews Millikan, André-Marie Ampère, Georg Simon Ohm, Kamerlingh Onnes, Thomas Alva Edison, Nikola Tesla, Ernest Orlando Lawrence, César Lattes, J.J. Thomson, Willian Crookes, Wilheim Eduard Weber, James Clerk Maxwell, Wilhelm Conrad Röntgen e Bertrand Russel.

A seção "Tópico Especial”, diferente das biografias, está separada dos textos que têm o conteúdo disciplinar. No final da cada um dos oito temas, distribuídos em três unidades, foi colocado um Tópico Especial que contém textos históricos ou sobre as aplicações tecnológicas da física. O texto apresentado nessa seção descreve a evolução dos conceitos da física, mostrando brevemente as razões cientificas que levaram uma teoria ser mais aceita do que outra. No entanto, o conflito de idéias, os debates entre os

\footnotetext{
${ }^{172}$ Ibid. pág. 34.
} 
cientistas e os fatores sociais, culturais e econômicos que influenciaram na evolução da física são pouco mostrados. No texto "A descoberta do elétron" "173, por exemplo, são abordadas as experiências e hipóteses acerca de certos fenômenos que levaram à construção da teoria do elétron. Isso é realizado através de um texto que mostra as indagações dos cientistas e os meios que levaram a obter respostas ou novas perguntas. A seção começa dizendo do estudo da condução de eletricidade através de gases. Depois, cita que "os cientistas verificaram um fato inesperado: mesmo quando um alto vácuo era alcançado, o amperímetro continuava a indicar a passagem de corrente ${ } 174$.Esse fato levou Crookes a fazer uma nova experiência, que apresentou em seus resultados algo que ele imaginou ser radiação, que foi denominada de raios catódicos. Indo nessa direção, o texto apresenta outras experiências que Crookes fez para tentar desvendar esse fenômeno. Logo após, Thomson é apresentado como cientista que expôs uma teoria que diz que os raios catódicos eram constituídos por partículas, os elétrons.

As dúvidas e questionamentos dos cientistas mostrados nesse trecho trazem aos alunos uma ciência que foi aos poucos construída e debatida. Isso deveria ser bastante enfocado, pois mostra o dinamismo e atividade dos cientistas frente às questões formuladas. Infelizmente, não são mostradas nesses trechos as questões sociais que impulsionaram o avanço da ciência. Ao identificar os objetivos da sociedade na época das descobertas e ver o contexto social que o cientista estava inserido, o estudante pode ter uma visão mais critica e relacionar aspectos sociais coma física. Em paralelo, a prática dessa comparação pode gerar o hábito de fazer a mesma comparação em relação as questões atuais.

O livro possui cinco seções "Tópico Especial” que trazem temas de historia da ciência, sendo elas: "as primeiras descobertas no campo da eletricidade", "o gerador de Van der Graaff", "variação da resistência com a temperatura", "o ciclotron" e "a descoberta do elétron".

No capítulo "A Nova Física” é apresentada uma visão da física desenvolvida nas ultimas décadas do século XX. Através de um desenvolvimento histórico similar ao da seção Tópico Especial, os autores tratam das particulares elementares, a nova teoria gravitacional e o mundo das estruturas complexas.

\footnotetext{
173 Ibid. Pág. 277.

174 Ibid.
} 
No total, levando em consideração os textos das biografias, das seções "Tópico Especial” e do capítulo "A nova Física", a história da física aparece em 41 páginas (9,5 \% do livro / nem todas as páginas contabilizadas estão preenchidas completamente com textos de história da física).

Cotidiano: A proposta inicial do livro é de ensinar física a todos os alunos. A justificativa, descrita no critério "objetivos explícitos", é que a física está em nosso dia a dia. Ou seja, a física não interessa apenas aos estudantes que vão seguir uma profissão que envolve a física. Os demais alunos precisam ter um certo conhecimento para ter sua cidadania.

No livro, o cotidiano aparece de duas formas: ao longo do texto dos capítulos, em textos breves, que explicam em poucas linhas o funcionamento de certos materiais elétricos, e na seção Tópico Especial, que faz uma abordagem mais ampla dos fenômenos elétricos no cotidiano.

Os textos localizados ao longo do livro abordam os seguintes temas: blindagem eletrostática, pilha seca, bateria de automóvel, choque elétrico e suas consequiências, lâmpadas, fusível, curto-circuito, riscos e cuidados nas instalações elétricas, bomba de água, pilhas e baterias, como se forma a imagem em um tubo de televisão, eletroímã (receptor telefônico e alto falante), usinas geradoras de energia elétrica, ondas de rádio, microondas, raios-X, laser e transmissão de energia elétrica. Esses textos são curtos e abordam apenas o funcionamento desses dispositivos eletrônicos.

O livro possui três seções "Tópico Especial” que fala sobre fenômenos que estão presentes no cotidiano dos estudantes, são eles: "rigidez dielétrica - poder das pontas", "a válvula eletrônica e o transistor" e "transmissão e distribuição de energia elétrica". Da mesma forma que os textos espalhados pelo livro, essa seção traz apenas a explicação dos fenômenos ligados ao cotidiano. Essa explicação é bem formal e, em alguns casos, trazem algumas contas e fórmulas. Em nenhum momento é estabelecida, através da relação ciência-tecnologia-sociedade, uma visão crítica sobre os temas abordados.

No entanto, em alguns textos, como o "O choque elétrico e suas conseqüências", o aluno aprende que é preciso utilizar a eletricidade com responsabilidade para não causar danos aos outros e a si mesmo. Essa aprendizagem forma um cidadão mais consciente e responsável frente às ações cotidianas. 
Infelizmente, os temas do cotidiano são diretamente apresentados aos estudantes, sem existir um diálogo anterior no intuito de perceber os objetivos, intenções e realidade dos estudantes. Através do diálogo e construção mútua do conhecimento o estudantes se sente mais motivado e se integra ao sistema educacional. Ou seja, pode acontecer que alguns dos temas do cotidiano apresentados não sejam de interesse do aluno, tornando aquele conhecimento desinteressante.

No total, levando em consideração os textos espalhados no livro e as seções “Tópico Especial” citadas, os temas que abordam o cotidiano do aluno aparecem em 31 páginas $(7,1 \%$ do livro / nem todas as páginas contabilizadas estão preenchidas completamente com temas do cotidiano).

Aulas de experimentos: uma das propostas descritas pelos autores do livro é a realização de experiências com materiais de baixo custo. Assim, escolas que não possuem um laboratório, ou os instrumentos necessários, têm a possibilidade de fazer experiências cientificas com seus estudantes.

As experiências são apresentadas na seção "Algumas Experiências Simples", localizada no final de cada tema abordado no livro. As primeiras experiências realmente são realizadas com materiais de baixo custo e de fácil localização, como caneca de metal, papel de seda, pente de plástico, pedaço de lã, entre outros. No entanto, a partir da terceira seção de experiências (são oito ao total), é necessário ter alguns instrumentos como um gerador Van de Graaff, placas de zinco e cobre entre outros. Certamente esses instrumentos são ainda mais acessíveis do que ter um laboratório formal, porém, o professor vai ter que adquirir algumas coisas para colocar a experiência em prática.

Na seção, a experiência é descrita em texto e, logo após, o aluno tem que responder algumas perguntas. Essas perguntas, que são qualitativas, orientam o aluno a observar os fenômenos físicos na experiência. Em grupo, essas perguntas podem gerar alguma discussão entorno do fenômeno visualizado. No entanto, as perguntas não são abertas e não dão oportunidade para uma discussão maior de opiniões, pois não estão relacionadas, em nenhum momento, com a sociedade que cerca o aluno (e, conseqüentemente, com seu cotidiano). Logo, essa atividade não gera nenhuma posição crítica do aluno.

Em uma das experiências é proposta a construção de uma pilha.. O texto indica, passa passo, os procedimentos para a construção de uma pilha constituída por um par de placas de zinco e cobre colocada em um meio ácido (solúvel). Através de um 
voltímetro, o aluno verifica a f.e.m. da pilha em diferentes situações, mudando o meio ácido e trocando a placa de zinco por outras de materiais diferentes. O texto então exige a comparação dos fenômenos observados e a explicação dos resultados das experiências tendo em vista o conteúdo apresentado no capítulo. Em nenhuma parte do texto é relacionado à pilha com o cotidiano do aluno, como o consumo de pilhas por materiais elétricos. Também não é discutido, por exemplo, o problema da disposição das pilhas após sua utilização. Essa questão é muito importante, pois envolve questões educacionais e de cidadania como a devolução das pilhas e coleta seletiva, a utilização correta das pilhas (impedindo o habito de colocar pilhas dentro das geladeiras para conseguir energia) e a economia consciente de energia. No texto, é citada, em poucas frases, a atuação do cientista italiano Alessandro Volta. Essa citação apenas indica o nome do cientista que inventou a pilha e a data que de criação. Não é discutido o impacto que a pilha teve na sociedade, a mudança industrial e social, a possibilidade de transporte pessoal de energia, entre outros. Perde-se então a oportunidade de propor um debate que envolve questões sociais e a física, não tendo assim uma educação que incentive uma postura crítica do estudante.

No total, as experiências aparecem em 18 páginas (4,2 \% do livro / nem todas as páginas contabilizadas estão preenchidas completamente com experiências).

Exercícios e problemas: O livro "Curso de Física" possui cinco níveis de exercícios e problemas: "Exercícios de Fixação", "Revisão", "Problemas e Testes", "Questões de Vestibular" e "Problemas Suplementares". Os "Exercícios de Fixação" aparecem constantemente no decorrer do texto da unidade e, de acordo com os autores, apresentam questões fáceis que contribuem como fonte de motivação e desmistificação a pretensa dificuldade que existe em relação ao estudo da física.

Após realizar os "Exercícios de Fixação", o estudante pode fazer os demais exercícios que, em sua grande maioria, necessitam de uma grande aplicação matemática. Apenas as questões da "Revisão" são descritivas, pois a proposta para essa atividade é de criar um resumo que pode servir para o aluno recapitular alguns conceitos.

Em todos os casos, os exercícios possuem respostas absolutas e finais. Ou seja, não é realizada nenhuma questão aberta que possibilite a discussão, troca de opiniões e abordagem de questões de nossa sociedade. Os exercícios, a princípio, estão direcionados apenas para verificar se o aluno aprendeu esse ou aquele conceito. 
Logo, os exercícios propostos, em seus diferentes níveis, passam uma ideologia onde o conhecimento é algo fechado e incontestável, apresentado nos livros como verdade que deve ser seguida e que possui uma resposta determinada dos exercícios no final do livro. Esse conhecimento não se origina então do debate e das falas dos colegas. A participação dos alunos e dos professores nessa proposta acaba por ser a de seguir fielmente os conceitos do livro, não os discutindo e não os relacionando com suas próprias vidas. E, ao não gerar o debate e conflito, propaga uma passividade e aceitação do conhecimento. O livro, nesse contexto, tem o objetivo de ser um sistema de entrega de fatos que são aceitos e cobrados nos exercícios. Nesse processo, o conhecimento se torna "legítimo" e uma cultura dominante é implementada.

O nível "Questões de Vestibulares" reforçam essa situação e mostram claramente a interferência dos exames vestibulares no ensino. O livro passa para o aluno a ideologia que para aprender determinado conteúdo é preciso resolver e acertar os exercícios de vestibulares. Esses exercícios se tornam o padrão de conhecimento.

No caso, a inserção das questões de vestibulares também retrata o interesse de lucro, já que a editora sabe que os exames vestibulares exercem uma força muito grande nos jovens que, por sua vez, procuram o ingresso no ensino Superior. Trata-se de um livro que possui um treinamento para a resolução de um exame de vestibular certamente vai ter um índice maior de venda.

No total, os exercícios: "Revisão", "Problemas e Testes", "Problemas Suplementares" e "Questões de Vestibular" aparecem em 108 páginas (25\% do livro / nem todas as páginas contabilizadas estão preenchidas completamente com exercícios / não foram contados os Exercícios de Fixação, pois eles aprecem ao longo de todo o livro).

\section{Interdisciplinaridade}

Ao longo do livro, a física se relaciona algumas vezes com a disciplina de história, nas partes referentes a historia da física, e com a disciplina de química. Nas correlações com a história, já descritas no critério Historia da Ciência, o estudante aprende que a ciência foi construída ao longo dos anos. Nos textos, essa construção envolve muitos debates entre os físicos e mostram a necessidade do diálogo para a construção do conhecimento. Mas, no livro, a evolução da física não se relaciona a questões históricas como guerras, momentos políticos e avanços territoriais para 
conquistas econômicas. A química aparece quando se trata da caracterização dos materiais em termos eletromagnéticos (se é condutor ou isolante, se é um material bom para circuitos elétricos, se o material vai ser um bom resistor ou condutor,...). Essa caracterização aproxima a química da física e mostra ao estudante que os conhecimentos interagem entre si. Em uma das experiências, a da construção de uma pilha a partir de duas placas, uma de zinco e outra de cobre, e um meio liquido ácido, é mostrada um resultado das duas disciplinas, a eletroquímica. Essa mesma experiência é tratada, geralmente, nos livros de química do Ensino Médio. O interessante é que no texto do livro Curso de Física o enfoque é físico e submete, em alguns momentos, aos conhecimentos de química.

No livro Curso de Física a interdisciplinaridade aparece em poucas páginas e quase todas elas envolvem história e química. Apenas em uma página é realizada uma referência a disciplina de geografia, ao mostrar a localização da magnésia na introdução sobre magnetismo. Tanto a geografia, como outras áreas do saber poderiam ser melhor aproveitadas. No tópico especial "Transmissão e distribuição de energia elétrica", os autores podiam falar da localização das usinas geradoras de energia elétrica, do impacto econômico e biológico das usinas, da comparação dos diferentes meios de energia e seus impactos políticos, e a comparação entre os paises e seus meios de energia. Assim, esse assunto relacionaria física com química, biologia, geografia e história. E, se no texto "Transmissão e distribuição de energia elétrica", fosse pedido aos alunos que fizessem uma investigação sobre o tema, exigindo assim uma interpretação de diferentes textos e elaboração de uma redação, para posterior debate, o tema abrangeria também a disciplina de português.

De todas as partes que envolvem interdisciplinaridade, a mais interessante se encontra no capítulo "A Nova Física", onde os autores tratam do significado da ciência e envolvem em seu discurso várias áreas do saber como química, biologia e cosmologia. Também tratam no texto de pesquisas atuais de físicas e mostram como existe a interrelação entre as áreas do saber. Uma pena que esse texto se encontre no capítulo 25 , na página 267. Seria muito proveitoso se esse texto fosse o primeiro a ser visto pelos alunos. Assim, todas essas informações serviriam de motivação a aprendizagem e mostrariam, logo de início, uma visão de ciência mais ampla e interdisciplinar. 


\section{Filosofia da Ciência}

O livro "Curso de Física" apresenta o significado de ciência nos textos explicativos colocados no inicio nos capítulos, nos exercícios, nas partes onde é abordada a historia de ciência e nas experiências propostas.

Nos textos explicativos, os autores colocam o conhecimento como sendo um produto acabado e verdadeiro. Neles, as explicações são levadas como regras imutáveis a serem obedecidas sem questionamento. Essa abordagem, que lembra o cientismo, leva o estudante a ter a física como um objeto de confiança ilimitada a ser seguida de forma dogmática e repetida. Em uma parte, na página 154, é descrito que: "todos os dispositivos elétricos que são utilizados para aquecimento se baseiam no efeito Joule. Assim, um ebulidor, um chuveiro, um ferro elétrico,...consistem essencialmente em uma resistência que é aquecida ao ser percorrida por uma corrente." O texto poderia abordar a questão de forma a trazer o debate e questionamento. Os autores poderiam partir das seguintes perguntas: Que aparelhos elétricos vocês tem em casa? Como podemos dividir eles em grupos que indicam alguma similaridade? Em relação aos aparelhos que produzem calor, qual o fenômeno envolvido que leva a mudança de temperatura? Existe alguma teoria que explica esse fenômeno? Qual o alcance dessa teoria? Ela se aplica a todos os aparelhos elétricos em todas as situações? Dessa forma, com essas perguntas a ciência é mostrada com outras características.

Os exercícios, nesse sentido, reforçam o cientismo ao exigir a repeticão da teoria explicada. As questões fechadas devem ser trabalhadas para atingir uma resposta única, absoluta, que denota uma dogmatização e aceitação imposta do conhecimento transmitido. Aliás, a grande maioria dos exercícios tratam apenas de aplicação de fórmulas matemáticas, não permitindo o debate e troca de idéias entre os alunos e entre os alunos com o professor. Para uma formação questionadora é necessário exibir questões que não sigam uma resolução única e com um resultado absoluto. É preciso apresentar questões que promovam diferentes trajetórias de resolução, onde o aluno reflita e discuta suas idéias com os demais.

Já nos textos sobre Historia da Ciência que não tratam da biografia dos cientistas, os debates entre os cientistas e o avanço da ciência através da troca de idéias traz uma visão de ciência mais próxima da proposta por KUHN. Nos textos é mostrando brevemente as razões científicas que levaram uma teoria ser mais aceita do que outra. 
Infelizmente, questões sociais e históricas que interfiram nos avanços na ciência não são contempladas. $\mathrm{O}$ desenvolvimento da física fica restrito apenas a física em si.

Por vez, as experiências são tratadas, sobretudo, como meio de verificação da teoria. Em seus itens, os estudantes seguem uma serie de instruções lineares que fazem com que uma observação de um fenômeno confirme um conhecimento visto anteriormente. Na experiência proposta na página 206, um dos itens diz que "para verificar que a f.e.m. da pilha depende da solução na qual as placas estão mergulhadas, introduza as placas de cobre e zinco em uma solução (...)”. Em outra parte diz: "Verifique, agora, que a f.e.m. depende também do material que constitui cada placa. Para isso, substitua a placa de zinco por uma de ferro e meça a f.e.m." Ou seja, tendo aprendido a teoria, a experiência serve para reafirmar ou confirmar os conceitos vistos. A experiência então não pretende trazer novas perguntas ou incitar novas idéias e olhares para o fenômeno observado. Cabe ao estudante apenas seguir as etapas propostas e observar que a teoria ensinada pelo professor era verdadeira.

Logo, ao longo do livro "Curso de Física", é possível perceber diferentes tendências de filosofia da ciência. Os textos históricos trazem aspectos que se aproximam da visão de ciência de KUHN. Acredito que essa parte é fundamental para a formação de aluno crítico. No demais, na parte teórica, o texto não traz as tensões conceituais das idéias de KUHN. 
Distribuição dos conteúdos em relação aos critérios de análise

A seguir é apresentada uma tabela que mostra a distribuição dos conteúdos do livro em relação a alguns critérios escolhidos para análise.

Tabela 2. Distribuição dos conteúdos do livro em relação aos critérios escolhidos para análise para o livro Curso de Física

\begin{tabular}{|l|c|c|}
\hline & $\mathrm{N}^{\circ}$ de páginas & \% em relação ao total de páginas \\
\hline Introdução e Índice & 19 & 4,4 \\
\hline Texto teórico & 194 & 44,9 \\
\hline Exercícios & 108 & 25,0 \\
\hline História da Física & 31 & 9,5 \\
\hline Cotidiano & 41 & 7,1 \\
\hline Experiências & 18 & 4,2 \\
\hline Resposta dos exercícios & 19 & 4,4 \\
\hline Tabela e Anexos & 2 & 0,4 \\
\hline Total & 432 & 100,0 \\
\hline
\end{tabular}




\section{Conclusões sobre o livro:}

Antônio Máximo Ribeiro da Luz e Beatriz Alvarenga Alvarez são autores que possuem uma formação e atuação voltada às questões do ensino de física. Participaram de atividades educacionais no Ensino Médio e Superior, contribuem com artigos e orientações em pós-graduação e demonstram em seus artigos e palestras uma preocupação com a Educação do país. A editora Scipione, criada em 1983, trabalha com livros didáticos e paradidáticos. Em 1999, a editora Scipione foi adquirida pela Editora Abril em parceria com o grupo franco-espanhol Havas Anaya, controlado pelo grupo francês Vivendi Universal Publishing. Atualmente, a Scipione tem mais de 1.400 títulos em seu catálogo e investe em cursos de capacitação de professores, palestras com autores, assessoria pedagógica personalizada, além de campanhas institucionais.

No Curso de Física, os autores dizem de forma explicita que o objetivo principal do livro é de oferecer um ensino para todos os alunos, inclusive para aqueles que não pretendem seguir uma profissão que necessite de física. Um dos objetivos citados por eles é a abordagem dos conceitos de física presentes no cotidiano para motivação do aluno. Ao longo do livro, essa abordagem aparece poucas vezes, mais precisamente em 31 páginas, correspondendo a 9,5\% do livro. Em contraposição, a quantidade de exercícios propostos é muito grande. Eles aparecem em 108 páginas, 25\% do livro, sendo grande parte deles direcionados para o vestibular. Esses exercícios são formulados de tal forma que não exista uma discussão mais ampla entre os alunos e entre professor e aluno. Na grande maioria são questões com resultados absolutos e que necessitam apenas de manuseio matemático das fórmulas físicas.

O conteúdo de história da física, por sua vez, remete um olhar diferenciado para a ciência e seu desenvolvimento. Os textos, que infelizmente são poucos (quase $10 \%$ do livro), apresentam uma sucessão de fatos que mostra algumas vezes as indagações dos cientistas. Isso é muito interessante, pois mostra uma ciência que está sempre sendo construída, não é algo fechado e pronto. Essa postura traz também uma filosofia da ciência que se aproxima das idéias de KUHN. No entanto, não chega a apresentar os debates e dificuldades políticas e econômicas que os cientistas enfrentaram. Isso poderia incitar o aluno a tomar uma postura mais crítica ao ver que os cientistas, em seu ambiente de trabalho, discutem efetivamente e enfrentam situações sociais que muitas vezes mudam o curso de suas pesquisas. 
Ou seja, o livro possui tendências diferenciadas. Em certas partes, nos exercícios, o livro parece objetivar uma formação direcionada para solução de exercícios e aplicação matemática, sem questionamento da teoria e relação social. Em outras, em partes históricas e do cotidiano, o livro traz um material que proporciona uma reflexão sobre o dinamismo da evolução da ciência e os debates entre os cientistas. Com essa reflexão, o livro consegue fazer com que o estudante tenha uma formação mais questionadora, incentivando assim uma postura crítica frente às questões. Esses dois objetivos distintos são de fácil observação, pois o livro segrega o conteúdo em seções que separa a parte dos exercícios da parte da histórica, por exemplo.

Esse formato proposto pelos autores possivelmente se origina da pesquisa realizada por eles em relação aos objetivos que um livro possuir. Nas primeiras páginas do livro, os autores comentam que dialogaram com vários professores e escolas e, com levantamentos estatísticos, constataram que as modificações ocorridas na educação no país dificultam o processo de aprendizagem. Dizem que a diversidade de temas proposta nas novas mudanças educacionais fazem com que o professor tenha que trabalhar com temas muito diversos. Além disso, nesse contexto, se torna muito difícil fazer um livrotexto que se adapte a tanta diversidade. Assim, os autores decidiram por fazer um livro que leve os conceitos fundamentais de física. Esses conceitos foram seccionados em nível de dificuldade e foi indicado ao professor que escolha as seções que vão na direção dos anseios do seu público alvo.

O interessante dessa abordagem é que previamente foi realizada uma pesquisa para ver quais eram os interesses dos professores e escolas. E, depois, na prática escolar, o professor pode escolher quais temas vão ser abordados. Apesar dessa metodologia significar um avanço, pois permite a entrada de idéias do professor, a construção do conhecimento e do conteúdo fica a cargo dos autores do livro. E, devido a estrutura linear dos conteúdos, o professor tem pouca liberdade de escolha. Podendo apenas abordar ou não temas históricos, do cotidiano, experiências e aplicar exercícios mais específicos e de maior dificuldade, como os dos exames vestibulares.

No corpo do texto ou na prática escolar, nem os alunos e nem os professores podem interferir na construção do conhecimento. O livro não permite a inserção de opiniões e comentários dos estudantes. Ao longo de seus textos e exercícios, o conteúdo é apresentado sem questionamento. Os alunos tem que ler, compreender e reproduzir aquele conhecimento em exercícios que apresentam apenas uma única resposta. 
A impressão que fica para o aluno é que a física é uma disciplina de exercícios, de aplicação matemática. Essa impressão também fica para o professor, pois grande parte do livro do professor é a resolução desses numerosos exercícios Esse condicionamento, onde o aluno é passivo e tem que seguir uma série de exercícios para verificar se esta aprendendo faz com que o estudante não tenha uma atitude participativa e questionadora. Aliás, ao oferecer a física como um rol de exercícios que têm respostas prontas e que devem ser obedecidas, o aluno acaba aceitando esse conhecimento como sendo verdadeiro, como sendo legítimo.

Reunindo todas essas informações e as observações realizadas nos critérios de análise, pode-se dizer que está inferido nesse livro um currículo que, em sua ideologia, transmite duas classes de valores distintas. A primeira, que envolve a história e o cotidiano, tem uma tendência mais próxima dos $\mathrm{PCN}$ :

- ao compreender a física como uma construção humana e mostrando a continuidade de uma teoria e a ruptura de paradigmas. Essas características aparecem claramente nos textos históricos que mostram os debates entre os cientistas e a evolução da ciência.;

- identifica e relaciona instrumentos tecnológicos utilizados no dia a dia e os relaciona com os conhecimentos passados nos textos teóricos. Isso ocorre nas seções que tratam do cotidiano e nas experiências;

- apresenta textos interdisciplinares, relacionando na grande maioria das vezes a física com a química e história. Mas a estrutura de capítulos não segue uma proposta interdisciplinar, os temas são organizados a partir da ordem fenomenológica;

- identifica e exercita o conhecimento de variáveis através de gráficos, diagramas, desenhos e expressões algébricas. Aliás, grande parte do livro se dedica a isso;

- ao compreender e aplicar conceitos físicos e estratégias matemáticas nas situações cotidianas e no manuseio de instrumentos tecnológicos. Muitas vezes, nas seções de experiência e do cotidiano, é exigido do aluno que ele aplique fórmulas matemáticas e conceitos físicos para compreender um determinado fenômeno. 
O livro, contudo, não relaciona diretamente o desenvolvimento cientifico com a transformação da sociedade e não avalia a intervenção humana na realidade natural, não propõe uma compreensão não-determinística dos fenômenos sociais e naturais (quase todos os exercícios apresentam respostas absolutas), não analisa dados, de forma qualitativa e quantitativa, relacionando-os a contexto socioeconômico e não relaciona o desenvolvimento tecnológico aos problemas que se propuseram a solucionar (os textos do cotidiano trazem apenas a explicação do funcionamento dos aparelhos elétricos. Nem os textos históricos indicam a necessidade da criação ou descoberta de certos conceitos e tecnologias). Ou seja, dos três setores de competência descritos nos PCNs, o Curso de Física trabalha bastante com representação e Comunicação, já que trabalha bastante com símbolos, representações, equações e esquemas, mas não faz argumentações críticas em relação a temas de cidadania e tecnologia; exercita pouco a Investigação e Compreensão, pois apenas as experiências propostas incitam a interpretação dos dados, medição e cálculo para a compreensão dos fenômenos observados; e não aborda a competência da Contextualização Sociocultural, ao não realizar as relações entre desenvolvimento tecnológico contemporâneo, conhecimento cientifico e o mundo cotidiano.

Essa primeira tendência também se aproxima do ENEM, ao desenvolver as competências de domínio da linguagem matemática e científica, através dos muitos exercícios propostos aos alunos, e da aplicação dos conhecimentos de várias áreas do saber para compreensão dos fenômenos naturais e da produção tecnológica, quando o aluno interage com os textos que possuem caráter interdisciplinar. Porém, as competências de selecionar, organizar, relacionar e interpretar dados e informações e de relacionar informações para posterior aplicação em situações concretas e argumentação consistente são pouco desenvolvidas. Nos textos históricos o estudante vislumbra um fenômeno sendo estudado por diversas perspectivas, que se confrontam e avançam a ciência, mas os textos não promovem um debate entre os estudantes. Apenas no confronto de idéias contrárias, na prática, e da busca por informações e opiniões diferentes, o estudante vai realmente entender e aprender como tomar decisões, enfrentar situações-problema e construir argumentações consistentes. A competência que trata da intervenção solidária na realidade, assim como a competência Sociocultural do PCN, não são abordadas nos textos do livro.

Já a segunda tendência, que também aparece nos PCNs e ENEM, no que diz respeito do aprendizado de representações, equações, gráficos e diagramas, se aproxima 
mais dos exames vestibulares, que propõem, na sua grande maioria, exercícios que só testam a destreza matemática. Os exercícios vestibulares também possuem respostas fechadas, absolutas e que não permitem o debate entre os alunos. Nesse esquema, que constitui uma avaliação, o estudante tem que mostrar sua docilidade ao apresentar métodos e resoluções que seguem um padrão de conhecimento inquestionável, imposto e tido como verdadeiro, pois é exigido para o ingresso no Ensino Superior. Ou seja, a aplicação dos exercícios dos exames vestibulares, ou de exercícios similares, serve para treinar os estudantes a responderem as questões certas nos momentos certos. Assim, é garantido o sonhado ingresso ao Ensino Superior e, quem sabe, a um futuro melhor. Devido ao grande interesse no Ensino Superior, principalmente das classes média e alta, os livros tendem a colocar exercícios dos exames vestibulares, pois assim as editoras atendem a um público certo e garantem as vendas e lucro. Aliás, levando em consideração o valor do livro didático e a renda média das famílias de grande parte dos alunos hoje no Ensino Médio, percebe-se que as editoras atendem os alunos com melhor situação sócia econômica, que por sua vez tem grande interesse em continuar os estudos depois do Ensino Médio.

Essa situação, que foi debatida por APPLE, e que envolve um sistema de cobrança de conhecimento, como uma Avaliação Nacional; o mercado de livros; a proposição de passar o conhecimento como sendo legitimo, e inquestionável, e os interesses de passar uma ideologia aos estudantes no sentido de formar cidadãos passivos, obedientes e que saibam exercer técnicas que podem ser aplicadas nas industrias e empresas, reforça uma situação educacional do Brasil, que desestimula o estudante de estudar e o professor de ensinar.

O livro Curso de Física apresenta essas duas tendências antagônicas, colocadas em espaços separados e que servem a diferentes objetivos. Possivelmente, devido a biografia dos autores, Beatriz e Antônio tentam colocar em seu livro um pouco das vontades e anseios dos professores e escolas e um pouco das suas vastas experiências na pesquisa do ensino de física, seja na área acadêmica, seja no cotidiano escolar. De qualquer forma, o livro desses autores, por pertencer a uma grande editora, tem que atender a certos interesses do mercado. E, nesse combate, é possível observar duas tendências de ensino, fundada em ideologias contraditórias. 


\subsection{Análise das apostilas "Leituras de Física: Eletromagnetismo" (elaborado pelo GREF - Grupo de Reelaboração do Ensino de Física"}

Descrição geral: As apostilas "Leituras de Física: Eletromagnetismo" foram elaboradas pelo GREF - Grupo de Reelaboração do Ensino de Física, sendo publicadas em junho de 1998 pelos mesmos. O GREF foi um grupo formado por professores da rede estadual de ensino de São Paulo e coordenados por docentes do Instituto de Física da Universidade de São Paulo. O grupo iniciou seus trabalhos em 1984 e, além de oferecer formação continuada, cursos e assessoria a professores de física, elaboraram as apostilas do GREF e três volumes, publicados pela Editora da Universidade de São Paulo, direcionados ao professor. Parte dos professores do grupo continua ainda hoje propondo atividades ligadas ao GREF.

O GREF foi composto pelos professores Anna Cecília Copelli, Aurélio Gonçalves Filho, Carlos Toscano, Elisabeth Barolli, Isilda Sampaio Silva, Jairo Alves Pereira, Maria Lúcia Ambrózio, Maria Sumie Watanabe Sátiro, Suely Baldin Pelaes e Victoriano Fernandes Neto. Esses professores da Escola Publica do estado de São Paulo foram coordenados pelos professores João Zanetic, Luís Carlos de Menezes e Yassuko Hosoume. O GREF de eletromagnetismo ainda teve a colaboração do professor Manoel Roberto Robilotta, do Instituto de Física da Universidade de São Paulo.

João Zanetic, Doutor em Educação pela USP (1990), é professor do Instituto de Física desde 1970 e tem como linha de pesquisa a historia da física no ensino, os aspectos filosóficos da metodologia em física, a relação do ensino de física no Ensino Médio com a cultura, a relação da física com a literatura e o nascimento da mecânica. Zanetic participou de eventos de ensino, publicou artigos em revistas especializadas em ensino de física e orientou mestrados e iniciação científica em ensino de física.

Luís Carlos de Menezes, Livre Docente junto ao Instituto de Física, na área de Educação (1988), é professor do Instituto de Física desde 1968 e tem como linha de pesquisa a formação de professores, ensino e aprendizagem, currículo, avaliação e mecânica estatística. Menezes participou de eventos de ensino, publicou artigos em revistas especializadas em ensino de física e orientou doutorados e mestrados em ensino de física.

Yassuko Hosoume, Doutora em Educação (1986), foi professora do Instituto de Física (1973-1999) e desde 1999 e continua como orientadora de Pós-Graduação em 
Ensino de Ciências e tem como linha de pesquisa a formação de professores, ensino e aprendizagem, currículo, avaliação e mecânica estatística. Yassuko participou de eventos de ensino, publicou artigos em revistas especializadas em ensino de física e orientou doutorados, mestrados e iniciação científica em ensino de física.

As "Leituras de Física: Eletromagnetismo" são direcionadas para o estudante e possui 5 apostilas divididas em 40 capítulos, formando assim um conjunto de 160 páginas. As apostilas têm dimensão $27,2 \mathrm{~cm}$ por $21,2 \mathrm{~cm}$, são em preto e branco e podem ser adquiridas gratuitamente na Internet em arquivo "pdf" (http://axpfep1.if.usp.br/ gref/pagina01.html). Logo, a qualidade do papel impresso depende do tipo de folha que será utilizado na impressão do arquivo.

Junto às apostilas, o GREF elaborou o livro do professor, chamado "Física 3 Eletromagnetismo". Sua $5^{\circ}$ edição, $1^{\circ}$ reimpressão, foi publicada em 2002 pela Editora da Universidade de São Paulo (EDUSP) e, diferente das apostilas, pode ser apenas adquirido em livrarias. O livro do professor possui 440 páginas, em preto em branco, impresso em papel Officet linha dágua 75g (a capa foi impressa em papel cartão supremo 250g). Foram impressos 3.000 exemplares, distribuídos em todo o país, pelo valor de capa de 32 reais ${ }^{175}$.

O "Física 3 - Eletromagnetismo" tem, inicialmente, uma apresentação geral da proposta do GREF, explicitando as metas do grupo. Depois é apresentada uma abertura e plano de curso para aqueles professores que adotarem as apostilas do GREF. O restante do livro, que são 400 páginas, constitui um texto que serve de base de leitura para o professor e, por isso, possui mais conteúdo do que o livro para o aluno. Esse conteúdo também é dividido, ao longo do livro, em capítulos que apresentam uma estrutura diferente da apresentada no livro dos estudantes. No entanto, ambos os textos estão relacionados.

Com essa leitura o professor vai rever os conceitos de física pela perspectiva do cotidiano, que é a proposta do GREF. Também são propostos exercícios que são diferentes dos exercícios encontrados no livro para o aluno. Dizem os autores do GREF, sobre o livro do professor, que: "Não é demais acrescentar que é convicção dos elaboradores desse texto que cada professor de Física deva ter condições e tempo para, continuamente, avaliar sua própria atuação, desenvolver-se enquanto profissional e

${ }^{175}$ Valor obtido no dia 1 de março de 2005 na EDUSP. 3091-4150 
aperfeiçoar seus instrumentos de trabalho. A seqüência de textos que inclui este volume é só um estimulo nesta direção" $" 176$.

Objetivos Explícitos: Na seção "Apresentação geral da proposta"177, no livro para o professor, os autores dizem que o intuito do GREF era apresentar uma Ciência de tal forma que fosse possível ver sua universalidade e relevância prática. Com isso, pretendia-se tornar o aprendizado cientifico mais significativo, inclusive para os alunos que não tinham como objetivo um futuro profissional que dependesse diretamente da física. E, ao mesmo tempo, era objetivo dar uma base que fosse suficiente para que os alunos pudessem ter condições de acesso a um entendimento conceitual e formal consistente para posterior ingresso no ensino superior. Sobre essa postura, os autores dizem que o "caráter prático-transformador e o caráter teórico-universalista da física não são traços antagônicos, mas isto sim, dinamicamente complementares" ${ }^{\prime 178}$. Com esse enfoque foi elaborado um texto que não era tecnicista e nem formalista. Pelo contrário, os textos, de acordo com os autores, sempre tentam partir de elementos vivenciais e cotidianos, garantindo assim uma física que oferece utilidade prática e universalidade.

Nesse sentido, tanto a forma quanto o conteúdo foram repensados. No GREF, cada assunto é desenvolvido através de uma linguagem comum ao professor e ao aluno. Essa linguagem é ampliada a medida que se aumente a área comum de compreensão e domínio do conhecimento. No início do curso, por exemplo, deve ser realizado um levantamento de "coisas" que o aluno e professor associem aos conceitos físicos que vão ser abordados. Para os autores, essas associações fazem com que a estrutura conceitual do curso comece a ser revelada ao aluno. Nessa proposta, o professor consegue identificar, através da participação ativa dos alunos, saber quais são as áreas de interesse e conhecimento que os estudantes tem. Com isso, o aluno também se familiariza mais com o estudo, pois está associando conceitos de física com "coisas" de seu cotidiano.

Dizem os autores que esse levantamento, que configura uma pesquisa do docente, permite a articulação dos elementos a serem estudados e complementam o aprendizado teórico-formal. Sendo assim, as situações do cotidiano não são colocadas a

\footnotetext{
${ }^{176}$ Grupo de Reelaboração do Ensino de Física. Física 3: Eletromagnetismo / GREF. $5^{\circ}$ Edição. São Paulo: EDUSP, 2002. pág. 21.

${ }^{177}$ Ibid. Pág. 19.

178 Ibid.
} 
parte das outras atividades propostas no livro como, por exemplo, os exercícios, observações e experimentação. Os temas e atividades se integram formando um corpo que mistura o cotidiano do aluno e o ensino de física.

Os autores também ressaltam que existem muitos aspectos que seriam interessantes de serem abordados nas apostilas do GREF, mas que não foram trabalhados. Indicam que a evolução da Ciência e do sistema produtivo, dentro de uma perspectiva da historia da ciência, seriam muito importantes para a formação do discente.

Por fim, é incentivado que os professores tenham uma continua avaliação de seu trabalho docente, devendo aperfeiçoar constantemente seus instrumentos de trabalho.

Protagonismo Discente: muitos dos questionamentos apresentados nas apostilas dos GREF remetem ao cotidiano do aluno. E os dados para a realização das atividades propostas devem, na sua grande maioria, serem obtidos pelo aluno em aparelhos elétricos e eletrônicos de sua casa. Isso gera uma participação ativa dos alunos na construção de seu próprio saber. Ou seja, o aluno não está fazendo a leitura de um mundo externo a ele, mas está observando e interagindo com elementos de sua vida que antes eram desapercebidos ou não compreendidos.

Sendo assim, o professor não traz todo o currículo pronto ao aluno, mas discute os elementos que constituem a cultura do aluno. E, a partir dos elementos e situações cotidianas, o professor apresenta ao aluno as aplicações e conceitos da física. Em uma das primeiras atividades, o aluno, por exemplo, tem que calcular sua conta de luz. Nessa atividade, os elementos elétricos que implicam na conta são determinados pelo aluno e o professor serve como um guia que vai auxiliar e explicar como se obtém os dados e como se organizam eles de tal forma a se chegar no valor indicado na conta de luz. Essa interação horizontal entre professor e aluno promove o diálogo e pode não permitir a imposição de uma ideologia.

Outras atividades, relacionadas aos exercícios, também incitam uma participação ativa do aluno na construção do saber. No capítulo 30, intitulado "Diferentes formas de comunicação", um exercício tem a seguinte pergunta: "Os micro computadores utilizam mensagens gravadas em diversos meios. Quais são eles?”. Para responder essa pergunta o estudante terá que buscar informações, conversar com colegas e professores, entre outros. Sua trajetória, que não é determinada previamente, dá uma liberdade de 
escolha muito grande ao aluno. E, as diferentes trajetórias, podem resultar em diferentes respostas, que se complementam e formam a construção coletiva.

Porém, as atividades não trazem perguntas que incitem a discussão sobre temas sociais. Na atividade da conta de luz poderia ter uma pergunta de tal forma que levasse a comparação e discussão sobre a matriz energética do país e a necessidade do uso consciente da energia elétrica. Isso levaria a um debate sobre cultura, economia e política. O mesmo poderia ser feito na atividade sobre os meios de computador. Poderia se perguntar qual o impacto ambiental de cada meio de gravação digital, ou como o avanço tecnológico muda os meios de trabalho e de consumo. Infelizmente, essas questões sociais, que poderiam trazer um olhar critico frente as questões da sociedade, não são abordados.

Estruturas dos temas: as apostilas "Leituras de Física" apresentam uma estruturação de temas que segue os objetivos explícitos. A ordenação e a seleção de conteúdos estão relacionadas a temas do cotidiano do aluno. No caso do volume estudado, a eletrostática passou a ser um mero detalhe no meio do eletromagnetismo, dizem os autores. Também comentam que parte da dificuldade sentida pelo aluno no aprendizado do eletromagnetismo vem de uma abordagem de conceitos muito abstratos, longe da realidade do aluno, como cargas puntiformes, força inversamente proporcional ao quadrado da distancia, entre outros. No entanto, o conceito do eletromagnetismo está presente no dia a dia do aluno. O estudante provavelmente já teve contato com máquinas, aparelhos elétricos e eletrônicos.

A proposta do GREF tem como objetivo, através de conteúdo e forma, discutir, através das situações cotidianas, os conceitos abstratos do eletromagnetismo. O interessante dessa estruturação é que os autores mostram que é possível integrar diretamente os temas cotidianos com os conceitos de física. Ou seja, o GREF não propõe o cotidiano como um capítulo ou seção à parte, mas relaciona dentro de sua estrutura a realidade do aluno e conhecimento a ser aprendido. As cinco apostilas para o aluno são divididas nos seguintes capítulos:

1. Onde não está a eletricidade?

2. Pondo ordem dentro e fora de casa

3. Elementos dos circuitos elétricos

4. Cuidado! É 110 ou 220? 
5. A conta de Luz

6. Exercícios

7. Chuveiros elétricos

8. Lâmpadas e fusíveis

9. A potência nos aparelhos resistivos

10. O controle da corrente elétrica

11. Ligações elétricas na residência

12. Circuitos elétricos e sua representação

13. Exercícios

14. Motores elétricos

15. Imas e bobinas

16. Campainhas e medidores elétricos

17. Força magnética e corrente elétrica

18. Força e campos magnéticos

19. Exercícios

20. Usinas geradoras de eletricidade

21. Dínamo de bicicleta

22. Transformadores no circuito

23. A corrente elétrica vista por dentro

24. Fumaça, cheiros e campos

25. Exercícios

26. pilhas e baterias

27. Força e campo elétricos

28. A interação elétrica e seu papel

29. Exercícios

30. Diferentes formas de comunicação

31. Alo,...pronto. Desculpe, engano!

32. Radio ouvintes

33. Plugados na Televisão

34. Luz, câmara,..., AÇÃO!

35. Transmissão área de informações

36. Radiações Eletromagnéticas

37. Salvando e gravando

38. Tamanhos são documentos 


\section{Partículas e interações}

\section{Exercícios}

De forma geral, os capítulos tratam de aparelhos resistivos, motores elétricos, fontes de energia elétrica, elementos de sistemas de comunicação e informação, materiais semicondutores e componentes elétricos e eletrônicos.

História da Física: Tanto no livro do professor quanto nas apostilas para os alunos não existem textos sobre a história da física. Dizem os autores, na seção "Apresentação geral da proposta" "179, no livro do professor, que alguns aspetos, como a historia da evolução da ciência e do sistema produtivo, que seriam de grande interesse, ainda não foram desenvolvidos em seus textos, ficando a cargo do professor a busca desse material.

No entanto, no capítulo 39, denominado "Partículas e interações", é mostrada brevemente a evolução do conhecimento da constituição da matéria e suas interações básicas. Esse texto traz a evolução do conhecimento da matéria, passando por Demócrito (se. 4 a.c.), Dalton (1808), Thomson (1897), Rutherford (1911), Bohr (1913), Chadwick (1932) e Gell-Mann (1960). Esses textos, de um parágrafo cada, trazem um pequeno recorte das propostas de modelos da matéria de cada época. Depois são citadas as interações e as leis de conservação de energia. O interessante desse capítulo está na sua parte final, nos exercícios, onde é pedido para fazer uma comparação entre os modelos atômicos. Nesse exercício é possível comparar as idéias dos cientistas, identificando assim as quebras de paradigmas e visões sobre a matéria. Infelizmente, o GREF tem apenas esse texto sobre historia da física.

Cotidiano: todas as páginas das apostilas Leituras da Física do GREF estão ligadas a temas do cotidiano. Tanto a estruturação e conteúdo foram elaborados pensando nas possíveis aplicações de conceitos físicos no cotidiano. A primeira atividade do capítulo 1 da apostila do aluno, por exemplo, é realizar um levantamento das atividades que o aluno fez no dia, como acordar, escovar os dentes, pegar o ônibus, etc. Depois, o aluno deve verificar qual dessas atividades dependeu da eletricidade. Essa discussão se estende ao capítulo 2, onde o aluno agora tem que classificar, de alguma

\footnotetext{
${ }^{179}$ Grupo de Reelaboração do Ensino de Física. Física 3: Eletromagnetismo / GREF . $5^{\circ}$ Edição. São Paulo: EDUSP, 2002. pág. 21
} 
forma, as atividades que ele realizou que dependem da eletricidade. Essa classificação deve ser dividida então, após uma discussão entre professor e alunos, em: aparelhos resistivos, motores elétricos e instrumentos de medidas com ponteiros, fontes de energia elétrica, elementos de sistemas de comunicação e informação e componentes elétricos e eletrônicos. Com isso o estudante pode visualizar todo o curso e seus objetivos já em seu início. Os demais capítulos tratam sempre de elementos do cotidiano e acabam por trazer uma aprendizagem voltada para a cidadania. No capítulo 5, por exemplo, a apostila explica como se calcula a conta de luz a partir de informações obtidas em cada instrumento elétrico ou eletrônico.

Para os autores do GREF, essa abordagem do cotidiano faz com que o ensino seja mais significativo para o estudante. O aluno consegue através dessa proposta perceber o porque é importante estar estudando. E, ao perceber isso, acaba se motivando a estar estudando cada vez mais. Os exercícios, que remetem também a questões do dia a dia, fazem com que o estudante interaja com o meio em que vive e observe as situações com um olhar diferenciado, carregado de conhecimento e dúvidas que, ao serem orientadas pelo professor, formam uma trajetória do conhecimento de forma bem pessoal e única.

Os capítulos 7, 8, 9, 10 e 11 da apostila do aluno, em especial, têm uma abordagem muito próxima do cotidiano. Esses capítulos tratam de observar os aparelhos dentro de casa e de uso diário. No capítulo 7, o texto começa com uma série de perguntas sobre chuveiro. Essas perguntas são aos poucos esclarecidas ao longo do capítulo e culminam em exercícios de aplicação da física no entendimento do funcionamento do chuveiro. No capítulo 8, o aluno aprende sobre lâmpadas e identifica as diferenças entre os valores indicados nas caixas de lâmpadas, como potência, corrente e voltagem. Essa compreensão, que relaciona a física com o cotidiano, faz com que o estudante tenha maior consciência no momento de comprar uma lâmpada ou uma lanterna, por exemplo. Já no capítulo 11, o assunto se aprofunda tanto, que por vezes o texto trata das ligações elétricas em uma residência de uma forma técnica, indicando um conhecimento mais específico e aplicado de eletromagnetismo. Os conhecimentos passados são muitas vezes vistos pelos alunos de forma abstrata e por esquemas, como no caso da ligação em paralelo e em série. No GREF, essas ligações são vistas de forma aplicada, relacionando, os capítulos anteriores sobre chuveiro, lâmpadas e aparelhos resistivos e o formato da rede elétrica das casas e das ruas. Isso gera uma maior 
curiosidade e aproximação entre o objeto de estudo e a cultura do discente. No caso, entende-se o porque de aprender tais conhecimentos.

Isso fica muito presente no capítulo de exercícios. O exercício 8 , tem o seguinte enunciado: "Numa residência, geralmente, chegam três fios da rua, dois fases e um neutro, que são ligados à chave geral. A) Faça o esquema de uma chave geral e de três chaves parciais, de modo a obter duas chaves de distribuição de $110 \mathrm{~V}$ e outra de $220 V^{\prime}$. Esse exercício reúne os conhecimentos dos capítulos anteriores e traz elementos próximos da realidade do aluno.

$\mathrm{Ou}$ seja, todas as atividades do GREF estão permeadas pro questões do cotidiano, trazendo assim uma aprendizagem mais significativa para o estudante.

Aulas de experimento: as apostilas do GREF propõem ao aluno algumas experiências ligadas ao cotidiano. Essas experiências, na maioria das vezes, utilizam instrumentos simples e baratos. Isso é bom, pois facilita sua aplicação em comunidades mais carentes. Apenas duas experiências mostraram um grau mais elevado de dificuldade, pois, em uma, era necessário possuir um determinado tipo de dínamo e, na outra, era preciso ter placas de cobre, zinco e acido acético.

No conjunto das cinco apostilas foram propostas as seguintes experiências: "construa você mesmo um motor elétrico", "investigação com imas, bússolas e bobinas", "campainha", "galvanômetro", "para fazer e pensar: aproximando caneta eletrizada de pedaços de papel", "dínamo de bicicleta: o gerador arroz com feijão", "construção de uma pilha", "acumulador de cargas" e "rádio sem pilha (sem bateria, sem tomada,...)".

No "rádio sem pilha (sem bateria, sem tomada,...)", o estudante monta o radio de galena. No livro do professor é encontrado um pouco de historia, relacionando a experiência com o contexto histórico. Diz o texto que:

"A partir do inicio do século $\mathrm{XX}$, foram introduzidos nos receptores de radiofreqüência certos cristais que permitem a passagem de corrente elétrica num sentido, (...) O cristal de galena foi utilizado durante muito tempo devido a sua grande eficiência na deteç̧ão das ondas de rádio, sendo inclusive empregado na 
construção de receptores improvisados durante a Segunda Guerra Mundial". ${ }^{180}$

Infelizmente, essa abordagem histórica não aparece nas apostilas para os estudantes. No entanto, o docente, ao ler o livro do professor, pode mostrar as passagens históricas para os alunos.

Essa experiência, que reúne conceitos de recepção, sintonia, detecção e reprodução, apresenta os conceitos mais importantes de eletromagnetismo, abordando o funcionamento da bobina, do diodo, do capacitor, da aplicação do fio terra, da antena e do fone de ouvido. Ao construir esse rádio, que tem um custo muito baixo, o estudante consegue observar os fenômenos aplicados em um instrumento que é utilizado por muitas pessoas no dia a dia.

Além disso, antes da experiência, o capítulo apresenta uma serie de exercícios que instigam a curiosidade e a elaboração do radio de galena. No caso, é perguntado "Para que servem as pilhas ou a energia elétrica que chega através dos fios?", "Qual a função do circuito oscilante na recepção de uma estação de rádio?" e "Indique as transformações pelas quais passa o som desde sua origem, na estação, até este chegar junto a um ouvinte." Essas perguntas, que muitas vezes contrariam o senso comum, instigam os alunos. Alias, um rádio que funciona sem pilha é um instrumento que faz o estudante pensar sobre o que significa energia.

De forma geral, nas seções de experiência são elaboradas perguntas qualitativas que orientam o estudante a observar os fenômenos físicos ali envolvidos. Essas perguntas podem, em grupo, gerar alguma discussão. Porém, nenhuma das perguntas leva o estudante a fazer uma reflexão crítica da sociedade que o cerca. Ou seja, os experimentos relacionam apenas os conceitos físicos com elementos práticos do cotidiano, como rádio, pilha, entre outros. No rádio de galena, por exemplo, o texto poderia remeter aos contextos históricos que impulsionaram o desenvolvimento do rádio, ou poderia se discutir os diferentes meios de comunicação, tecnologia e as relações entre as desigualdades sociais e o acesso a informação.

No total, as experiências aparecem em 9 páginas das cinco apostilas.

\footnotetext{
${ }^{180}$ Ibid. pág. 385.
} 
Exercícios e problemas: nas apostilas "Leituras da Física" os exercícios, na sua grande maioria, não precisam utilizar operações matemáticas muito complicadas. Muitas vezes, as perguntas trazem uma reflexão da leitura do texto ou uma aplicação ou observação de algo que acontece no dia a dia do aluno. No capítulo 5, por exemplo, um exercício pede para se calcular o consumo de energia elétrica de uma casa. Já no capítulo 11 é apresentado um exercício onde o aluno tem mostrar a forma certa de fazer as ligações elétricas em uma casa residencial.

De forma geral, existem duas modalidades de exercícios: "o exercitando"... e o "teste seu vestibular...". Essas duas modalidades de exercícios estão espalhadas nos capítulos e, em alguns casos, formam um capítulo inteiro (capítulos 6, 13, 25, 29 e 40). Os exercícios do "o exercitando..." trazem questões qualitativas e quantitativas. E, por muitas vezes, os exercícios admitem mais de uma resposta correta.

No capítulo 9, que trata da potência nos aparelhos resistivos, uma questão interessante é apresentada. Nela, uma pessoa vai comprar uma lâmpada para sua cozinha e, ao colocar a lâmpada, percebe que a luz produzida era bem fraca. Dada as especificações da lâmpada nova e da que estava anteriormente na cozinha, é pedido ao aluno explicar, por comparação, por que o brilho da nova lâmpada não era tão intenso. Depois, na segunda parte do exercício, é pedido para o aluno fazer uma sugestão de qual a melhor lâmpada para a situação. Nesse exercício é possível explorar muitas variáveis reais que podem resultar em respostas diferentes. Alguns estudantes podem dizer que a resposta depende do tamanho da(s) janela(s) da cozinha, ou de quantas lâmpadas tem a cozinha, ou se a cor das paredes ajudam ou não na luminosidade do ambiente, ou no custo da lâmpada (da lâmpada e da conta de luz), entre outros. Essas respostas certamente vão aparecer quando houver o envolvimento do aluno e de sua cultura no exercício. No caso, possivelmente o estudante de uma classe social alta vai ter uma resposta diferente de um aluno de classe social baixa. Assim, o exercício permite uma resposta que segue as peculiaridades do cotidiano de cada aluno, respeitando sua classe social, seus valores e significados.

Mas nem todos os exercícios abordam apenas questões do dia a dia. Quando os temas são aprofundados, exercícios mais específicos são apresentados, indicando uma continuação e aproximação do objeto de estudo. No capítulo 29, questão 11, o aluno tem que identificar as cargas elétricas em esquemas que representam as linhas de campo elétrico. Essa questão, que não trata do cotidiano, faz com que o estudante reflita mais 
sobre os conceitos de física, após ter tido uma introdução que relacionou seu dia a dia com a disciplina de estudo.

Os exercícios compreendidos na seção "teste seu vestibular..." são, em sua maioria, de múltipla escolha e necessitam de mais aplicação matemática do que os exercícios do "exercitando...". No "teste seu vestibular", as questões são fechadas, possuem apenas uma resposta correta e tratam apenas da aplicação direta dos conceitos em situações abstratas, distantes do cotidiano. Na questão 8 , do capítulo 29 , tem a seguinte questão:

"Três pequenas esferas estão carregadas eletricamente com cargas $q_{1}, q_{2}$ e $q_{3}$ e alinhadas sobre o plano horizontal sem atrito, conforme a figura. Nesta situação elas encontram-se em equilíbrio. A carga da esfera $q_{2}$ é positiva e cale $2,7.10^{-4} \mathrm{C}$. a) determine os sinais das outras cargas. b) calcule os valores de $q_{1}$ e $q_{3}$. c) se $q_{1}$ e $q_{3}$ forem fixas o que acontecera com $q_{2}$ ?"

Essa questão, que exige do estudante certas ferramentas matemáticas, está distante do dia a dia e apenas requer o conhecimento específico de uma área do eletromagnetismo. Sua resposta é determinada e absoluta, não permitindo um debate e contribuição do aluno e do professor.

Tanto as questões do exercitando quanto os exercícios de vestibular não apresentam questões que tratam de questões sociais, políticas, econômicas e culturais. Apesar dos exercícios do exercitando trazerem elemento do cotidiano, esses não incitam um olhar crítico sobre os problemas enfrentados por nossa sociedade. As questões abertas permitem que o professor aborde essas questões, mas elas não aparecem explicitamente nos textos das apostilas do GREF. Por ser tratar do eletromagnetismo, poderia ser abordadas a distribuição de energia do país e suas conseqüências, as relações de energia e poder entre os paises, a precariedade e falta de infraestrutura de locais menos privilegiados encontrados nas periferias das grandes cidades, entre outros. Isso poderia formar um estudante que critica certas situações sociais, promovendo assim uma formação de luta contra a situação imposta que favorece uma determinada parcela da sociedade. 


\section{Interdisciplinaridade}

Ao longo do livro, a física se relaciona poucas vezes com outras disciplinas. Bem no início das apostilas do GREF, na pagina 4, tem um texto bem interessante sobre a eletricidade no corpo humano. Nesse texto é abordado como nos enxergamos as coisas através de impulsos elétricos do olho para o cérebro. Essa parte relaciona a física com a disciplina biologia, na parte de estudo sobre o corpo humano. Depois, na parte de pilhas, na página 102 e 103, os autores falam da pilha eletroquímica e fazem comparações com as pilhas atuais. Nessa parte a química é relacionada com a física, em relação à combinação de materiais condutores com ácidos e propriedades de certos materiais que permitem a condução de corrente elétrica. A relação entre química e física é reforçada com uma experiência onde o estudante tem que montar uma pilha com duas placas de cobre e duas de zinco, papel higiênico, um pedaço de esponja de aço, acido acético e led ou lâmpada de 1,2 volts.

Por fim, na página 154, é realizada uma interação entre física, historia e química, na seção "Do que é formada a matéria e como estão organizadas as partículas que a formam?”. Essa seção traz o desenvolvimento histórico do conhecimento do que é formada a matéria. Em apenas uma página são abordados os principais modelos atômicos e as descobertas das partículas que constituem o átomo. Esse tema é normalmente abordado no início do curso de química e retrata um panorama que depois vai conduzir as ligações atômicas, formação de substâncias, moléculas e as interações entre diferentes substâncias. Nesse sentido, essa seção complementa e oferece uma visão da matéria sobre a perspectiva da física. Por colocar os diferentes modelos atômicos e sua evolução no tempo, também é possível relacionar a historia com a física.

Nas apostilas do GREF então é possível identificar apenas 4 páginas que relacionam a física com outras disciplinas.

\section{Filosofia da Ciência}

Nas apostilas do GREF, o significado de ciência é tratado em seus textos, exercícios e experiências. Nos textos explicativos, a ciência, no caso a física, é apresentada junto com elementos do cotidiano. Assim, todo fenômeno ou conceito físico é ligado a alguma aplicação no dia a dia do estudante. Essa abordagem pode fazer com que o estudante pense que a física é desenvolvida apenas para a construção de 
novos instrumentos de uso cotidiano. E, quando o aluno aplica os conceitos de física no seu dia a dia, nas experiências e exercícios, ele reforça a idéia de que a física é uma ciência que está finalizada, pois consegue explicar todos os fenômenos que envolvem os instrumentos encontrados na realidade dos estudantes. Essa abordagem, que não mostra a evolução da ciência e indica uma física com regras imutáveis que devem ser seguidas, lembra o cientismo.

Essa filosofia da ciência é reforçada pela ausência de textos de história da ciência. Mesmo a parte que trata dos modelos atômicos é muito superficial e apenas cita os modelos dos cientistas. As discussões entre os cientistas, o momento histórico, as questões econômicas e políticas que interferiram nas descobertas e invenções não são apresentadas. São apenas colocados, na página 154, pequenos textos:

“1911: Rutherford fez uma celebre experiência e propôs um novo modelo de átomo: existe um núcleo, formado de cargas positivas onde a massa do átomo esta quase toda concentrada. Os elétrons estão fora do núcleo, girando em torno dele.

1913: N. Bohr aprimorou o modelo de Rutherford: os elétrons giram ao redor do núcleo em órbitas definidas

1932: J. Chadwick fez a suposição de uma nova partícula no núcleo do átomo: os nêutrons. Acertou na mosca!"

Nas experiências, o estudante segue uma série de instruções lineares que fazem com que o um fenômeno seja observado e relacionado à teoria vista anteriormente. E, nas apostilas do GREF, isso fica mais presente, pois as experiências parecem ter como objetivo explicar os instrumentos do cotidiano do aluno. Aliás, as experiências normalmente só trazem no texto as instruções para a montagem de um determinado instrumento. No texto não são realizadas, na grande maioria das vezes, perguntas que poderiam incitar uma discussão sobre a teoria aplicada, observando assim limites da teoria e a visão de uma ciência que está sempre se desenvolvendo.

Enfim, todos os textos das apostilas do GREF uma ciência que explica coisas do cotidiano. A ciência não é questionada, não é relacionada com fatores históricos e não é tratada a partir das relações da física com a economia, cultura, política e sociedade. 


\section{Distribuição dos conteúdos em relação aos critérios de análise}

A seguir é apresentada uma tabela que mostra a distribuição dos conteúdos do livro em relação a alguns critérios escolhidos para análise. No caso das apostilas do GREF, o item texto teórico foi colocado junto com o cotidiano, pois todo o texto teórico envolve aplicação em elementos do dia a dia do aluno.

Tabela 3. Distribuição dos conteúdos do livro em relação aos critérios escolhidos para análise para as apostilas do GREF.

\begin{tabular}{|c|c|c|}
\hline & $\mathrm{N}^{\circ}$ de páginas & \% em relação ao total de páginas \\
\hline Introdução e Índice ${ }^{181}$ & 40 & $25 \%$ \\
\hline Texto teórico / Cotidiano & 68 & $42,5 \%$ \\
\hline Exercícios & 42 & $26,25 \%$ \\
\hline História da Física & 1 & $0,01 \%$ \\
\hline Experiências & 9 & $5,6 \%$ \\
\hline Resposta dos exercícios & 0 & $0 \%$ \\
\hline Tabela e Anexos & 0 & $0 \%$ \\
\hline Total & 160 & $100 \%$ \\
\hline
\end{tabular}

${ }^{181}$ Cada capítulo possui uma capa em um pequeno texto introdutório. 


\section{Conclusões sobre o livro:}

As apostilas "Leituras de Física: Eletromagnetismo", elaboradas pelo GREF, configura um projeto interessante, pois reúne professores da rede estadual de ensino de São Paulo e professores do Instituto de Física da Universidade de São Paulo que trabalham com educação. O resultado, como consequiência, é um formato bem diferente de livro didático, construído não apenas por um ou dois autores, mas por professores do ensino médio público, que vivem diretamente as dificuldades e desafios do dia a dia escolar, e por professores universitários, que contribuem com suas pesquisas em ensino e conhecimento mais amplo das propostas educacionais existentes no Brasil e no resto do mundo. Essa proposta de debater e produzir um produto coletivo é uma idéia abordada no capítulo 5.2, onde, no caso, se comenta como deveria ser construído um currículo nacional. Nesse capítulo, APPLE cita SMITH, O`DAY e COHEN, que comentam, por sua vez, que um currículo nacional só teria sucesso se fosse concebido como uma grande e cooperativa aventura de aprendizagem. Dessa forma, poderia não existir uma imposição ideológica, já que a construção se dá em um ambiente democrático, com a participação daqueles que vivenciam as situações escolares.

Nesse panorama, os professores universitários, por possuírem muitas contribuições no ensino, através de pesquisas, projetos e ação docente na formação de professores, trazem um novo olhar para as discussões sobre o que deve ser um livro didático de qualidade. Assim, o resultado mostra o comprometimento, valores e significados de pessoas que têm o interesse real em discutir educação.

Isso fica muito claro no objetivo do livro e na forma como ele foi concebido. As apostilas do GREF têm como objetivo principal proporcionar uma educação que contemple os conhecimentos levando em consideração o cotidiano do estudante. E, mais do que simplesmente inserir no seu texto seções separadas que abordam alguns elementos cotidianos, as apostilas do GREF têm uma estrutura de temas e uma relação professor-aluno bem diferente e que configuram uma proposta inovadora de ensino.

A estrutura de temas do livro tem como eixo elementos e situações cotidianas, aproximando assim os conteúdos a serem ensinados e a realidade do estudante. Os capítulos são divididos de acordo com o aprofundamento da disciplina e tem como ponto de partida sempre uma questão próxima à realidade do estudante. Essa proposta motiva o aluno, pois ele consegue ver a aplicação e relação de seu estudo com a sua própria vida. 
Além disso, o formato dos exercícios propostos nas seções "exercitando..." promovem uma participação do estudante ao propor que ele traga elementos de seu cotidiano para a aplicação e observação dos conhecimentos de física. Com isso, a construção do saber leva em consideração a cultura e realidade do aluno. Isso é muito positivo, pois é possível perceber uma abertura nas questões que permitem diferentes respostas que variam de acordo com o público que está utilizando as apostilas do GREF. A estrutura das apostilas do GREF não é totalmente flexível, mas seus exercícios, ao não proporem respostas absolutas e ao permitirem a inserção de dados e elementos do dia a dia do aluno, fazem com que a construção do conhecimento tenha a contribuição do próprio estudante.

Isso já não acontece nos exercícios de vestibular e nas experiências. Nos exercícios de vestibular, que são na sua maioria de múltipla escolha, é exigido do aluno apenas a aplicação de conceitos e fórmulas de física em problemas abstratos que possuem apenas uma resposta correta. Distantes da realidade do aluno, esses exercícios apenas restringem a participação do aluno, que deve seguir uma trajetória única e limitadora para obter o resultado esperado, sem discussão e sem interação com os demais colegas. Nas experiências, o estudante se depara com uma lista ordenada de atividades a ser seguida passo a passo e sem questionamento. Na parte das experiências são poucas as vezes que são colocadas questões sobre a experiência. Nesse sentido, a experiência serve apenas para mostrar como é possível reproduzir, em um formato mais simples, certos instrumentos elétricos existentes em nosso dia a dia. A experiência serve apenas para reafirmar a importância e legitimidade da teoria aprendida.

Apesar das experiências e exercícios de vestibular fugirem da proposta original, grande parte das apostilas segue a linha do cotidiano, a participação do aluno com elementos de sua realidade e a construção do conhecimento do aluno junto com o professor. Mas, infelizmente, a proposta das apostilas do GREF não tem uma continuação da participação do aluno ao ponto de ele perceber e criticar as situações políticas, econômicas, sociais e culturais de nossa sociedade. Ao inserir o cotidiano em quase todas as partes das apostilas, os autores poderiam incitar debates e diálogos acerca de como certas questões cotidianas, que estão sendo vista pelo olhar da física, envolvem questões sociais profundas. No capítulo 5.2, APPLE comenta que não basta tratar do cotidiano, com um currículo mais próximo da "vida real", para se ter uma formação critica onde os valores e significados são discutidos. Diz APPLE que é preciso identificar de quem é a visão da vida real que conta. Por isso, falta nas apostilas do 
GREF uma discussão sobre o cotidiano que o aluno está relacionando com os conceitos de física. Como as apostilas são de eletromagnetismo, poderiam ser abordadas questões de energia do país, o avanço da tecnologia e as mudanças na área do trabalho, os meios de comunicação e a restrição a informação as pessoas de baixa renda, a relação entre poder e energia entre os paises e suas consequiências no dia a dia, entre outros. Esses temas gerariam debates e também contribuiriam para uma postura crítica e ativa do estudante.

Além disso, a ausência da historia da ciência e de temas interdisciplinares dificultam um olhar questionador do discente. A ciência é então vista como algo que está concretizado e que explica todos os instrumentos elétricos existentes. A ciência passa a ser vista como algo que já está concretizado e que serve apenas para o desenvolvimento de novos instrumentos para a humanidade. Nesse olhar, a tecnologia e ciência se confundem. Se tivesse alguma abordagem histórica, o aluno poderia perceber o dinamismo da ciência, poderia identificar que ela não é só desenvolvida para fins que culminam na construção de instrumentos do dia a dia e que sua expansão está relacionada com questões políticas, econômicas, culturais e sociais que compõem o mundo em que o estudante está inserido. Perceber esses fatores é olhar o mundo com uma visão crítica, percebendo as ideologias que estão sendo impostas e o controle exercido por uma pequena parcela da sociedade. Ao não ver isso, o aluno apenas perceberá a utilização da física no cotidiano, que é importante, mas que sozinha não constitui uma formação que proporcione uma liberdade frente a uma ideologia imposta.

Reunindo todas essas informações e as observações realizadas anteriormente nos critérios de análise, é possível dizer que as apostilas do GREF caminham em direção de algumas idéias de APPLE, pois tentam em seus textos, através do enfoque do cotidiano, ter a contribuição da cultura do estudante na formação do conhecimento. Essas e outras idéias também seguem muito do que é dito nos PCN. A própria estruturação de temas do "Leituras de Física: Eletromagnetismo" lembra as sugestões realizadas no PCN mais. Em relação aos PCN, mas apostilas do GREF:

- O aluno identifica variáveis relevantes e seleciona os procedimentos necessários para análise e interpretação de resultados oriundos de processos e experimentos científicos e tecnológicos, pois em seus exercícios, textos de leitura e experiências são colocadas atividades, onde o estudante observa instrumentos elétricos e trabalha suas variáveis para fazer uma posterior 
análise, e as experiências, que reproduzem de forma mais simples o funcionamento de instrumentos elétricos do cotidiano do estudante;

- Possibilitam a identificação, análise e aplicação de conhecimentos sobre valores de variáveis, representados em gráficos, diagramas e expressões algébricas. Muitos exercícios, elaborados pelos autores e de vestibular exercitam essas qualidades levando o discente a realizar previsão de tendências, extrapolações, interpolações e interpretações;

- É possível, já que grande parte dos textos aborda temas do cotidiano, entender a relação entre o desenvolvimento das Ciências Naturais e o desenvolvimento tecnológico, e associar as diferentes tecnologias aos problemas que se propuseram e propõem solucionar;

- Consegue apresentar a aplicação das tecnologias associadas às Ciências Naturais na escola; no trabalho e em outros contextos relevantes para a vida do estudante;

- Aplica conceitos, procedimentos e estratégias matemáticas em situações diversas no contexto das ciências, da tecnologia e das atividades cotidianas.

Mas as apostilas do GREF não ajudam a compreender as ciências como construções humanas, entendendo como elas se desenvolvem, pois não possuem em seus textos a história da física; não contribui na aplicação e discussão do funcionamento do mundo natural, planejando, executando e avaliando ações de intervenção na realidade natural; não ajuda a compreender o caráter aleatório e não-determinístico dos fenômenos naturais e sociais, pois em grande medida se vê nos textos e nos exercícios uma física determinística; não relaciona o contexto socioeconômico na análise qualitativa e quantitativa de dados e representações gráficas que envolvem o conhecimento da física; não contribui no entendimento do impacto das tecnologias associadas às Ciências Naturais nos processos de produção e na vida social. Ou seja, dos três setores de competência descritos nos PCN, as apostilas do GREF trabalham bem a Representação e Comunicação, pois trabalham com símbolos, representações, equações e esquemas e os relacionam com tecnologia, mas não os relacionam com temas de cidadania; exercitam de forma interessante a Investigação e Compreensão, já que apresentam experiências que promovem a interpretação de dados, medição, cálculo e relação desses dados com elementos do dia a dia do aluno; e aborda a competência da 
Contextualização Sociocultural ao propor entre conhecimento científico e o mundo cotidiano. Porém, em relação à Contextualização Sociocultural, as apostilas do GREF não tratam das questões políticas, econômicas, culturais e sociais que estão presentes no conhecimento cientifico e na realidade do estudante, fazendo com que a formação não propicie diretamente o caráter ético do conhecimento científico e tecnológico.

Já em relação ao ENEM, as apostilas do GREF ajudam, em seus exercícios e textos, no domínio das linguagens matemática e cientifica, mas não tratam da norma culta da língua portuguesa e da linguagem artística; não constrói uma compreensão que faça o aluno entender os processos histórico-geográficos, da produção tecnológica e das manifestações artísticas, pois nos textos não é abordado a historia de ciência e a relação de questões sociais com os conceitos da física; contribue para a seleção, organização, relação e interpretação de dados e informações, para a tomada de decisões e enfrentamento de situações-problema, já que propõe problemas ligados ao cotidiano ao invés de elaborar questões abstratas que dificultam a transposição dos conhecimentos para problemas reais; trabalha com situações concretas, relacionando informações de diferentes formas; e pode ser trabalhado para elaborar propostas que respeitam os valores humanos considerando a diversidade sociocultural. Esse último item, em particular, é desenvolvido nos exercícios propostos, onde o aluno pode contribuir com elementos de seu dia a dia. Essa ação leva a aceitação da cultura do estudante, ao invés da imposição de uma ideologia que suprime os anseios e realidade das pessoas. E, se o professor promover o debate na sala de aula, a troca de elementos cotidianos entre os aluno vai potencializar o respeito pelos valores humanos e pela diversidade sociocultural.

Enfim, por ter sido configurado coletivamente, com professores da rede pública e com professores que pesquisam educação, as apostilas do GREF apresentam um currículo que tem tendências ideológicas muito próximas aos PCN e ao ENEM. A presença das questões de vestibulares é bem pequena frente aos textos e exercícios que envolvem o cotidiano. Sendo assim, sua proposta é bem diferente e se aproxima bastante das questões vivenciais dos estudantes. E os espaços onde o estudante pode contribuir vão contra a idéia de se impor uma ideologia na escola. Infelizmente, não é dada uma continuidade nessa proposta no sentido de levar questões sociais e relacionálas com os elementos do cotidiano e os conceitos de física. A historia da física, ausente nas apostilas do GREF, faz falta também para a construção de uma visão de ciência que faça o estudante compreender que as teorias são construídas por debates e que essa 
postura questionadora também deve ser tomada pelo discente em relação às questões sociais. Por fim, as apostilas do GREF apresentam um grande avanço na direção da participação do aluno e no confronto a uma ideologia que pode ser imposta por um grupo da sociedade. Mas esse confronto poderia ter melhor resultado se alguns elementos sociais fossem implementados no currículo das apostilas do GREF. 
10.3 Análise do Livro "Os Fundamentos da Física", V. 3 (autores: Francisco Ramalho Junior, Nicolau Gilberto Ferraro e Paulo Antônio de Toledo Soares)

Descrição geral: O livro "Os Fundamentos da Física", volume 3, foi redigido por Francisco Ramalho Junior, Nicolau Gilberto Ferraro e Paulo Antônio de Toledo Soares e sua $8^{\circ}$ edição foi publicada em 2003 pela editora Moderna. O "Os Fundamentos da Física" possui duas versões, uma para o aluno e outra para o professor. A versão do estudante tem 470 páginas, é colorida, tem dimensão de 20,4 cm por 27,5 cm, é distribuído para todo o país e tem preço sugerido de 79,50 reais. O livro de professor é dividido em duas partes, a primeira contendo um guia direcionado para o professor e a segunda parte é o livro do aluno na integra. A parte voltada para o professor tem 80 páginas, é em preto e branco, tem $20,4 \mathrm{~cm}$ por $27,4 \mathrm{~cm}$.

A parte voltada ao docente possui, inicialmente, um texto de uma página onde os autores explicam sua proposta. Depois, cada capítulo do livro do aluno é abordado. Essa abordagem conta, para cada capítulo, com um breve texto de dois parágrafos, onde são apresentados os conteúdos e objetivos propostos no capítulo (acompanha também uma proposta de planejamento, com uma sugestão de horas de aula para cada capítulo), e a resolução dos exercícios, que ocupa grande parte da parte direcionada ao professor.

Francisco Ramalho Junior cursou engenharia na Escola Politécnica da Universidade de São Paulo e é professor de Física em cursos pré-vestibulares. Nicolau Gilberto Ferraro é engenheiro metalurgista pela Escola Politécnica da Universidade de São Paulo, mestre em Engenharia Mecânica pela Escola Politécnica da Universidade de São Paulo e é licenciado em Física pelo Instituto de Física da Universidade de São Paulo. Alem disso, Ferraro é professor de cursos pré-vestibulares e de escolas do ensino médio e superior. Paulo Antônio de Toledo Soares é médico formado pela Universidade de São Paulo e professor de física em cursos pré-vestibulares e escolas do ensino médio.

A Editora Moderna trabalha na publicação e distribuição de livros didáticos, materiais de apoio e livros de literatura desde 1968. Em 2001, passou a fazer parte do Grupo Santilla, que atua na Europa e nas Américas. A Fundação Santilla, entidade privada, vem desenvolvendo, de acordo com o site da Editora Moderna, ações e eventos no intuito de debater a ação docente. Uma das ações é o "Moderna Formação", onde a 
editora oferece cursos semi-presenciais e a distância para instituições e educadores interessados em complementar sua formação.

Objetivos Explícitos: No Prefácio, localizado no livro para o aluno, os autores dizem que o livro relaciona as leis e os fenômenos físicos ao dia-a-dia e ao desenvolvimento de novas tecnologias, contempla alguns tópicos de História da Física e propõe experimentos com materiais simples e que podem ser encontrados com facilidade. Dizem os autores, que os textos sobre Historia da Física situam no tempo os cientistas, descrevendo seus trabalhos e descobertas. Com isso, dizem, que a ciência se revela com se estivesse em constante desenvolvimento. As experiências servem para colocar o aluno em atividade e em contato com os elementos estudados. Comentam no Prefacio que “...ao pôr a mão na massa para realizar as atividades, o aluno tenha o interesse pela Física aumentado e que ele possa compreender melhor a ciência..."

Além disso ressaltam, com veemência, a incorporação das mais recentes questões dos exames vestibulares das universidades brasileiras, ENEM e das Olimpíadas da Física. Em boa parte do texto, os autores também indicam como os exercícios elucidam os conceitos, fazem o aluno exercitar e assimilar os conceitos teóricos, revisão, complementam e aprofundam o conteúdo de física. Essa importância dada aos exercícios também é tratada no texto inicial do livro do professor. Nele, os exercícios são colocados como fundamentais ao aprendizado do aluno.

No livro do professor, na parte dirigida ao docente, na página 2 , os autores sugerem que seja dada o mínimo de aulas para o desenvolvimento de cada capítulo. Ressaltam que é importante o professor avaliar os itens que devem ser omitidos ou aprofundados de acordo com a necessidade das turmas e carga horária disponível. Como no livro do aluno, os autores indicam que no "Fundamentos de Física 3" existe uma grande quantidade de exercícios, divididos em blocos, onde cada bloco tem um objetivo diferente e que complementam o conhecimento teórico. Ainda comentam que o conteúdo de um capítulo deve ser trabalhado de tal forma que seja possível aplicar alguns blocos de exercícios. Nesse sentido fica claro, devido a veemência dos textos e continua reafirmação, que um dos objetivos dos autores do "Fundamentos de Física 3" é que o estudante consiga resolver exercícios e problemas de física.

Além disso, ainda no livro do professor, dizem que os autores que os professores poderão trabalhar os textos sobre Historia da Física, indicando, se for o caso, leitura e 
pesquisas adicionais. Sobre as atividades experimentais, dizem que os resultados delas poderiam servir de base para uma Feria de Ciências.

Por fim, nessa parte do livro ainda é descrita como deve ser à avaliação. No caso, deve-se utilizar três ferramentas: a) provas sob a forma de questões dissertativas; b) provas sob a forma de testes; e c) trabalhos de pesquisa ou de leitura e interpretação de livros paradidáticos ou, ainda, resolução dos exercícios que não tenham sido resolvidos em aula.

Ou seja, após verificar esses textos onde os autores colocam suas intenções, de forma explícita, sobre os objetivos do livro, fica claro que o principal meta é de fazer com o estudante consiga resolver o maior número de exercícios e problemas de física, já que é sugerido que o professor aplique os exercícios em cada atividade escolar e cobre, depois, sua aprendizagem em avaliações.

Protagonismo Discente: Antes do Sumário do livro do professor, os autores apresentam um texto que contém algumas explicações e sugestões de como utilizar o livro. Nesse texto é possível perceber três momentos: a realização dos exercícios, as atividades como leitura dos textos da Historia da Física e a realização dos experimentos e, por fim, uma proposta de avaliação.

O primeiro momento trata dos exercícios, que toma quase todo o livro. Diz os autores que uma possibilidade de aprendizagem é exposição de parte da teoria junto com o bloco de exercícios resolvidos. Em seguida, o estudante deve resolver os exercícios propostos. E, no fim do capítulo, o aluno tem que fazer mais exercícios. Ou seja, a proposta de ensino sugerida indica que o estudante para aprender deve fazer muitos exercícios do livro. Como esses exercícios tem respostas fechadas, que não permitem uma discussão maior que possibilita a opinião e cultura dos alunos, possuindo assim uma resposta única. A atividade do aluno é de seguir fielmente os conceitos apresentados no livro, sem questionar e tentando, ao máximo, acertar todas as perguntas, excluindo assim sua participação na construção do saber.

No segundo momento, que diz respeito a leitura de textos sobre Historia da Física e a realização de atividades experimentais, os autores indicam os professores "podem trabalhá-los com os alunos". Essa frase, a princípio, indica um esforço conjunto entre alunos e professores. No entanto, o livro não propõem nenhuma atividade que agregue a atividade do professor com a do aluno. Na parte da História da Física, o livro apresenta só um texto, sem perguntas, sem indicações de outras leituras, 
sem exposição da realização de uma outra atividade. Os experimentos trazem questões problematizadoras, que podem gerar uma discussão, mas que se limita ao entendimento do fenômeno físico observado, sem fazer referências ou debate da relação do experimento com a sociedade, de forma crítica.

E, para completar, no final, no terceiro momento, os autores indicam que a avaliação deve ser uma prova que pode ter: provas sob a forma de questões dissertativas, provas sob a forma de testes ou trabalhos de pesquisa ou de leitura e interpretação de livros paradidáticos, ou ainda, resolução dos exercícios que não tenham sido resolvidos em sala de aula. Assim, com esse método de avaliação, o aluno fica amarrado pois deve seguir um conhecimento que não foi construído democraticamente, que foi imposto, e no fim tem que provar que aceitou e que sabe manipular aquele conhecimento descrito no livro.

Nesse contexto, o estudante tem uma postura passiva, não questionadora, que deve seguir todas as propostas do professor. Já o professor é aquele que vai comandar e cobrar a realização das atividades de ensino, que estão descritas no livro. No fim, o conhecimento a ser trabalhado está no livro, nem o professor e nem o aluno participam de sua construção.

Estrutura dos temas: o livro "Os Fundamentos da Física" apresenta uma estruturação de temas organizado através de fenômenos físicos. O livro é dividido em 5 partes, compondo, ao total, 21 capítulos:

\section{Parte 1 - Cargas Elétricas em Repouso}

Capítulo 1. Eletrização. Força elétrica

Capítulo 2. Campo elétrico

Capítulo 3 Trabalho e potencial elétrico

Capítulo 4. Condutores em equilíbrio eletrostático. Capacitância e eletrostática

Parte 2 - Cargas elétricas em movimento

Capítulo 5. Corrente elétrica

Capítulo 6. Resistores 
Capítulo 7. Associação de resistores

Capítulo 8. Medidas elétricas

Capítulo 9. Geradores elétricos

Capítulo 10. Receptores elétricos

Capítulo 11. As leis de Kirchhoff

Capítulo 12. Capacitores

\section{Parte 3 - Eletromagnetismo}

Capítulo 13. Campo magnético

Capítulo 14. Força magnética

Capítulo 15. Indução eletromagnética

Capítulo 16. Noções de corrente alternada

Capítulo 17. Ondas eletromagnéticas

\section{Parte 4 - Introdução à Física Moderna}

Capítulo 18. Relatividade especial

Capítulo 19. Física Quântica

Capítulo 20 Física Nuclear

\section{Parte 5 - Analise Dimensional}

Capítulo 21. Análise dimensional

Nessa estrutura, o aluno estuda primeiro a eletrostática, seguindo para a eletrodinâmica, indo para o eletromagnetismo. No fim, são tratados assuntos que não se relacionam diretamente com o eletromagnetismo, que é a relatividade geral, física quântica e física nuclear. Essa estrutura lembra a ordem histórica do desenvolvimento das leis e teorias da física.

Essa proposta de organização de conteúdos não se parece com a sugerida pelos PCN. Os conteúdos não estão estruturados de acordo com algum eixo temático e, sendo assim, não aproxima os conteúdos de física da realidade do estudante. 
História da Física: os tópicos da Historia da Física aparecem no livro no decorrer do texto dos capítulos, em seções denominadas "História da Física" e no "mapa temporal", colocado logo após o prefácio, contendo eventos históricos gerais e data de nascimento e morte de cientistas, filósofos, escritores de literatura, artistas e músicos. Na grande maioria das vezes, a Historia da Física é apresentada através de biografias, contendo poucas vezes uma explicação das pesquisas desenvolvidas pelos cientistas. $\mathrm{Na}$ seção História da Física cujo o titulo é "Da Construção da Primeira Pilha à Invenção da Lâmpada Elétrica", por exemplo, o texto traz uma sucessão de invenções que inicia em Luigi Galvani, passa por Alessandro Volta, Georg Simon Ohm, Claude Pouillet, Charles Wheatstone, Gustav Robert Kirchhoff e termina em Thomas Alva Edison. No texto, o debate entre os cientistas é colocado de forma bem superficial e em nenhum momento é mostrada as dificuldades políticas, econômicas e culturais enfrentadas pelos cientistas.

“...Luigo Galvani, verificou que as pernas de rã, que suspenderá para secar por meio de presilhas de cobre num suporte de ferro, contraíram-se quando balançadas pelo vento. Galvani atribuiu a ocorrência à existência de correntes elétricas produzidas pelas próprias pernas da rã. Alessandro Volta, não concordou com a hipótese de seu colega biólogo. Para ele, as contrações eram devidas a uma corrente elétrica, mas produzidas de outro modo. Ao serem balançadas pelo vento, as extremidades livres das pernas suspensas tocavam o suporte de ferro." 182

Em outras partes, os eventos históricos são colocados de forma desconexa e empilhados um em cima do outro, descartando no texto os debates entre os cientistas e as diferentes teorias formuladas para a explicação de um único fenômeno. No texto "Do magnetismo ao eletromagnetismo", pouco é dito das equações de James Clerk Maxwell e sua reação na comunidade científica. $O$ mesmo se faz sobre a indução magnética, desenvolvida por Michael Faraday. Em uma parte dessa seção, comenta-se que a indução eletromagnética serviu de base para o surgimento de geradores mecânicos de eletricidade e transformadores. Nessa parte, os autores poderiam comentar o impacto na sociedade e na forma de trabalho que essa teoria ocasionou, poderia relacionar esse

\footnotetext{
${ }^{182}$ RAMALHO, Francisco Junior, FERRARO, Nicolau Gilberto, SOARES, Paulo Antônio de Toledo Os Fundamentos da Física. Vol. $38^{\circ}$. ed. São Paulo: Moderna, 2003. Pág. 126.
} 
impacto ao impacto das novas tecnologias no mundo contemporâneo do trabalho e, por fim, poderia promover um debate que gerasse uma reflexão no estudante sobre o envolvimento da tecnologia, forma de trabalho e desigualdade social.

De todas as partes que tratam da História da Física, uma traz uma abordagem diferenciada. O texto que fala sobre fissão nuclear explica os fenômenos e relaciona as pesquisas e trabalhos a questões sociais.

"A eclosão da Segunda Guerra Mundial acelerou as pesquisas visando conseguir a auto-sustentação da reação em cadeia que possibilitasse a confecção de uma arma. Secretamente o governo dos Estados Unidos (e presume-se que também o da Alemanha) empenhou esforços nessa direção." 183

Seguindo o texto, os autores descrevem a construção do primeiro reator com estado de auto-sustentação, as bombas atômicas e as consequiências dessas pesquisas. Através da leitura dessa parte em particular, o aluno pode discutir a ética na ciência, as interações da sociedade com a física, entre outros. Infelizmente esse texto se encontra no final do livro. Seria interessante que texto dessa natureza estivessem permeando todo o livro, do seu inicio até o fim.

No total, a Historia da Física aparece em 23 páginas e trazem um mapa temporal que mostra eventos históricos gerais e data de nascimento e morte de cientistas, filósofos, escritores de literatura, artistas e músicos, a invenção da xerografia (Chester Carlson), a natureza da eletricidade no texto "Do Âmbar à Pilha Voltaica", a gaiola de Faraday, a invenção da pilha no texto "Da Construção da Primeira Pilha à Invenção da Lâmpada Elétrica", a experiência de Millikan, o texto "Do Magnetismo ao Eletromagnetismo", a biografia de Einstein no texto "Einstein e seu tempo", a evolução do conceito de átomo, a dualidade onda-partícula, o principio da incerteza e a fissão nuclear.

Cotidiano: no livro os Fundamentos da Física, o cotidiano é distribuído em seções ao longo de todo o livro. No total, o livro trata sobre temas do Cotidiano em 37 páginas. São abordados os seguintes temas: A eletricidade estática no dia-a-dia,

${ }^{183}$ Ibidem. Pág. 427. 
máquina de xerox, raios-relâmpago-trovão, pára-raios, efeitos da corrente elétrica, unidades de energia e potência (em equipamentos elétricos), o relógio de luz, a conta de luz, tipos usuais de resistores, disjuntores, a emissão de luz na lâmpada incandescente, instalação elétrica domiciliar, o chuveiro elétrico, as pilhas secas, a bateria de chumbo, o flash eletrônico, o tubo de tv, os supercondutores (relacionados no texto com chips), o microfone de indução, o gravador magnético (videocassete), os cartões magnéticos, os detectores de metais, usina hidrelétrica, transformador, ondas de rádio e microondas, luz visível, infravermelho e ultravioleta, raios $X$, transmissão e recepção de ondas de rádio e célula fotoelétrica.

Normalmente, as partes reservadas ao cotidiano apresentam textos que explicam os fenômenos que acontecem no dia-a-dia dos estudantes. A partir desse texto não é colocada nenhuma pergunta ou atividade, ou seja, o cotidiano aparece apenas como um texto para leitura. Além disso, essa leitura não traz aspectos sociais que trazem uma reflexão crítica sobre o conteúdo de física.

No texto "Luz visível, Infravermelho e Ultravioleta" os autores discutem as consequiências da exposição prolongada da radiação ultravioleta em nossos corpos durante a exposição ao Sol. Comentam até como é calculado o fator de proteção solar (FPS). Nesse momento, poderia se discutir que o descontrole ambiental, gerado pela falta de consciência das indústrias, que por sua vez estão interessadas em ter lucro, ocasionam a destruição da camada de ozônio, que aumentam a incisão de raios ultravioleta. Assim, essa discussão proporcionaria uma reflexão crítica nos estudantes. Ao invés disso, é apenas colocada uma tirinha de quadrinhos onde um jovem, ao pintar com spray uma parede, leva bronca por estar utilizando um instrumento que causa a destruição da camada de ozônio.

Já no "O tubo de TV", as informações passadas são muito técnicas e não dão abertura para a participação do estudante, pois se trata de um texto fechado, sem perguntas abertas e sem proposta de atividades. É descrito sobre a televisão, na página 300, já em suas primeiras linhas, que: "Uma fonte de elétrons $F$, normalmente chamada “canhão”, emite um feixe eletrônico acelerado por uma tensão de milhares de volts, que atinge a tela T do televisor". Esse texto, que explica o funcionamento da televisão, poderia ter um outro tipo de abordagem, por exemplo, fazer uma questão aberta pedindo aos alunos listarem quais os instrumentos que geram imagens (televisão de tubo, televisão de plasma, cinema,...) e relacioná-los a diferentes aspectos sociais e econômicos. 
No entanto nesse e noutros casos, as seções sobre cotidiano, separadas do texto que contem os conteúdos de física, aparecem como uma leitura complementar, sem exigir nenhuma questão ou reflexão do estudante. Ou seja, o cotidiano é apresentado apenas como uma informação a mais ao ensino da física.

Aulas de experimentos: ao longo do livro são apresentadas, nas seções denominadas "Atividade Experimental" (localizadas no final de alguns capítulos), algumas atividades que envolvem experiências. No total, o "Os Fundamentos da Física" possui 8 páginas que trabalham com experiências. As experiências tratam da eletrização por atrito e indução magnética, do pendulo elétrico, do eletroscópio de folhas, da associação de lâmpadas, da ponte de Wheatstone, de experimentos com imãs, da experiência de Oersted, do campo magnético de um solenóide, da construção de um eletroímã e de uma investigação sobre a indução magnética.

Inicialmente, o texto guia o aluno para que ele consiga montar o experimento. Depois, são realizadas questões qualitativas acerca do fenômeno. Essas perguntas podem gerar uma discussão entre os alunos, mas as discussões serão só sobre fenômenos físicos, já que não são realizadas perguntas que relacionam a experiência com as questões sociais que o aluno vive. As experiências escolhidas pelo livro são muito limitadas, pois não permitem a inserção de temas sociais. Para aqueles que pretendem seguir para o ensino superior, principalmente para a área de exatas, as experiências podem trazer alguma contribuição. Mas para os outros alunos, as experiências pouco acrescentam em uma formação crítica.

$\mathrm{Na}$ atividade experimental "Construção de um eletroímã”, na página 327, inicialmente, são apresentados os materiais necessários para a experiência. Depois, são realizadas cinco etapas de montagem que são acompanhadas de algumas perguntas sobre os conceitos de física relacionados à experiência. Essas perguntas possuem apenas uma resposta possível, são completamente dirigidas a elaboração e explicação do fenômeno e não relacionam, em nenhum momento, o experimento a questões do cotidiano do estudante e a questões sociais, culturais, políticas e econômicas. $\mathrm{Na}$ primeira etapa, por exemplo, é pedido ao estudante a construção de um solenóide. Depois, esse solenóide é fixado em uma base e ligado, em suas pontas, a duas pilhas colocadas em série. Com uma bússola o estudante verifica a distribuição do campo magnético na região. Nessa situação são apresentação as seguintes questões: "Por que a agulha da bússola se desvia ao ser fechado o circuito? Qual a polaridade da bobina? 
Confirme essa polaridade aplicando a regra da mão direita". Esse tipo de pergunta, que requer apenas o conhecimento específico dos conceitos de física, é realizado nas outras etapas da experiência.

Esse formato se repete nas demais experiências, mostrando assim ao aluno uma atividade experimental desvinculada da realidade do estudante e que serve apenas para a comprovação da teoria e observação e reprodução dos fenômenos.

Exercícios e problemas: O livro tem 5 modalidades de exercícios: exercícios resolvidos, exercícios propostos, exercícios propostos para recapitulação, testes propostos e exercícios especiais. Os exercícios resolvidos se encontram ao longo da exposição da teoria e servem, para os autores, para analisar, elucidar e mesmo ampliar a teoria apresentada. Já os exercícios propostos, também encontrados ao longo da exposição teórica, têm como objetivo a propor o exercício e assimilação dos itens teóricos. No fim do capítulo ficam os exercícios de recapitulação que, além de possuírem um grau de dificuldade maior, revisam e completam o assunto tratado. Logo após estão os testes propostos, que são, na sua grande maioria, exercícios de vestibular. Por fim, em alguns capítulos, estão presentes os exercícios especiais que tem como finalidade aprofundar ainda mais os conteúdos.

Os exercícios resolvidos são, em sua grande maioria exercícios de aplicação da teoria em exercícios abstratos, sem aplicação em problemas reais, e que envolvem basicamente o trabalho com fórmulas matemáticas. As respostas desses exercícios são quase todos um valor que representa o resultado de uma equação aplicada a uma determinada situação. O exercício resolvido da página 54, por exemplo, é sobre o movimento de uma carga puntiforme carregada com $1 \mu \mathrm{C}$. Nesse movimento, de um ponto A até um ponto $\mathrm{B}$, é realizado um trabalho de $10^{-4} \mathrm{~J}$. Na primeira pergunta desse enunciado é pedida a diferença de potencial elétrico entre os pontos $\mathrm{A}$ e $\mathrm{B}$ e, depois, o aluno tem que dizer qual o potencial elétrico de A tendo B como ponto de referência.

Os exercícios propostos são muito parecidos com os exercícios resolvidos e exigem, na grande maioria, a aplicação de fórmulas em situações abstratas. Os exercícios de recapitulação são, na verdade, uma coletânea de questões similares aos exercícios propostos, onde, novamente, o estudante tem que aplicar fórmulas matemáticas para resolver as questões propostas. Por algumas vezes, se encontram exercícios de vestibular nos exercícios de recapitulação, como a questão 54, na página 63. Nessa questão da FUVEST, uma carga Q é colocada a uma distancia " 2 d" de uma 
outra carga -Q. Sabendo-se que o potencial elétrico no ponto A vale 5,0 V e que no infinito vale zero, o estudante tem que determinar o trabalho realizado pelo campo elétrico quando se desloca uma carga pontual de carga $1 \mathrm{nC}$ do infinito até o ponto A (localizado no mesmo eixo das cargas e a uma distância d da carga positiva) e do ponto A até o ponto $\mathrm{O}$ (localizado entre as cargas).

Os testes propostos têm um formato igual aos exercícios de recapitulação, mas todos eles são de exames vestibulares e são questões de múltipla escolha. E os exercícios especiais também são iguais aos demais, mas apresentação uma maior dificuldade no manuseio das fórmulas matemáticas. Ou seja, não existe um aprofundamento dos conceitos físicos, mas sim uma maior utilização das ferramentas matemáticas em situações mais complexas. Na questão 129, da página 285, é apresentada a seção transversal de três condutores paralelos e extensos. Eles estão posicionados nos vértices de um triangulo eqüilátero, possuem $10 \mathrm{~A}$ de corrente cada. Tendo uma distância de $2 \sqrt{ } 3 \mathrm{~m}$ entre as cargas e um condutor que tem a direção de corrente oposta aos demais, o estudante tem que calcular o vetor indução magnética resultante no ponto $O$, eqüidistante dos três condutores.

Logo, grande parte dos exercícios desenvolvidos no Fundamentos da Física 3 são aplicações de fórmulas matemáticas que geram um resultado absoluto. Muitos deles são de vestibular e passam uma imagem que aprender física é ter a capacidade de resolver contas matemáticas.

No total, o "Os Fundamentos da Física" possui 282 páginas que apresentam exercícios e problemas. Todos os exercícios, desde os que têm resposta descritiva até os testes, possuem respostas absolutas, fechadas, que não promovem uma discussão coletiva ou opinião do aluno. Ou seja, os exercícios têm como finalidade fazer com que o aluno caminhe sempre em uma direção única, com inicio, meio e fim bem determinados.

\section{Interdisciplinaridade}

No livro "Fundamentos da Física 3", são poucas as vezes que a física encontra outras disciplinas. No inicio do livro, ao descrever a carga elétrica, os autores passam um pouco sobre o conceito de átomo. Esse texto remete muito do que é visto na disciplina de química, principalmente no primeiro ano do Ensino Médio. Mais à frente, no capítulo de geradores elétricos, o tema pilhas secas e bateria de chumbo tratam de 
reações químicas. As pilhas secas são compostas por um invólucro de zinco, que constitui o anodo, em um pequeno carvão, que é o cátodo. Em torno desse sistema existe uma mistura de dióxido de manganês e carvão em pó. Nessa pilha também é encontrada uma mistura formada de cloreto de amônio, cloreto de zinco e água. Os autores descrevem no texto o funcionamento da pilha e ressaltam duas reações químicas do processo. Já a bateria de chumbo é constituída por várias pilhas associadas em série. Cada pilha é composta de placas alternadas de chumbo e dióxido de chumbo. O conjunto, que é imerso numa solução diluída de acido sulfúrico, passa por algumas reações químicas descritas no texto. Na reação, elétrons são liberados, gerando energia para um sistema.

Bem depois, no capítulo 18, que trata da relatividade espacial, os autores colocam um pequeno trecho que relaciona física e arte. Diz o trecho, da página 380, que:

"A relatividade proposta por Galileu e Newton na Física Clássica é reinterpretada pelos postulados de Einstein. (...) A escultura do relógio mole de Salvador Dali, dependurado, desfazendo-se, derretendo, dá a impressão de ser uma concepção artística da relatividade do tempo."

Porém, esse trecho está separado do texto principal, que aborda a aplicação de formulas matemáticas nos problemas sobre relatividade. Por fim, na parte final do livro, sobre Física Moderna, os autores discutem a composição da matéria e, por vezes, relacionam a física com a química.

Além desses trechos, a física se encontra com a historia nas seções dedicadas a história da física. Mas essas seções tratam de uma historia de biografias e distantes do contexto histórico que se interliga com as questões sociais, políticas, culturais e econômicas que caracterizam cada época. Com uma perspectiva que mostra apenas os acontecimentos, sem contextualizá-los, fica difícil o estudante perceber quais foram as variáveis que impulsionaram as pesquisas e debates científicos.

Sem levar em consideração as partes de historia da física, o "Fundamentos da Fisica 3" tem pouquíssimos momentos de interdisciplinaridade, isolando assim a física das demais disciplinas. Com isso, o livro oferece um conhecimento segregado, muito 
específico e que não dá margens à visualização das interações entre as diferentes áreas do conhecimento.

\section{Filosofia da Ciência}

No livro "Os Fundamentos de Física 3", os autores apresentam, ao longo de todo o texto um significado de ciência que lembra muito o cientismo. Nos textos explicativos, o conhecimento é descrito como sendo um produto acabado e incontestável. As explicações possuem uma linearidade onde as leis e teorias são colocadas de tal forma que o aluno não é estimulado a questionar o conhecimento oferecido. No capítulo 6 do livro "Os Fundamentos de Física 3”, na página 108, o texto, carregado de linguagens matemáticas, tem um formato que impede o questionamento do

aluno. É colocado no texto que: "O elemento de circuito cuja função exclusiva é efetuar a conversão de energia elétrica em energia térmica recebe o nome de resistor". Depois, os autores colocam a lei de Ohm e enunciam que "O quociente da ddp nos terminais de um resistor pela intensidade de corrente elétrica que o atravessa é constante e igual à resistência elétrica do resistor." Logo depois, os autores salientam que "Um resistor que obedece à lei de Ohm é denominado resistor ôhmico". Por fim, na página 110, é proposto um exercício de aplicação da lei de Ohm. O estudante, ao seguir esse texto, observa uma ciência inquestionável, que deve ser incorporada de forma dogmática e repetida no exercício proposto.

Os autores podiam abordar o assunto de outra maneira. Uma saída, por exemplo, seria pedir para os alunos fazerem uma classificação dos aparelhos elétricos que resultam em mudanças de temperatura. Depois, o aluno faria um levantamento dos dados que estão impressos nesses aparelhos, como potencia, voltagem, resistência, entre outros. Com esses dados, os estudantes comparariam os valores de diferentes aparelhos elétricos. Tendo esse primeiro contato com o assunto a ser estudado, o estudante retornaria ao livro e verificaria que existe uma teoria que explica o funcionamento desses aparelhos. O livro forneceria então subsídios para a atividade discente, ao invés de direcionar completamente as ações dos alunos. E, a partir dessa atividade, o livro poderia perguntar sobre: o alcance e validade da teoria de Ohm? quando ela foi inventada? Que fatores influenciaram os cientistas a pensarem sobre resistência? E em que situações a lei de Ohm não funciona. 
Esse caráter investigativo exigido por essas perguntas e que demonstram uma ciência dinâmica também não está presente nos muitos exercícios encontrados no "Os Fundamentos de Física 3". Os exercícios, em sua quase totalidade, exigem apenas a repetição da teoria explicada. As questões são fechadas e possuem apenas um resultado único e numérico. Ou seja, as questões exercitam a perícia matemática, em vez de treinar os conceitos de física. Esses exercícios não permitem o debate e troca de informações entre os estudantes. Fica então a impressão que a construção do conhecimento se dá em ações individuais, sem debate e seguindo uma ordem linear previamente definida.

Os trechos de Historia da Ciência, que poderiam trazer os debates e uma ciência que é constantemente discutida e construída, tratam os confrontos científicos de forma superficial. Muitas vezes, as invenções e descobertas são colocadas de forma desconexa um após o outro, dando assim a impressão de que não houve debates para definir a teoria hegemônica na comunidade científica.

As experiências, por fim, ao constituírem um rol de atividades a serem seguidas e apresentar questões fechadas sobre a teoria, demonstram um caráter mais comprovativo do que investigativo. Com a experiência o estudante consegue observar a atestar o conhecimento teórico visto anteriormente. Ou seja, a experiência não serve para instigar e promover uma abertura para que o aluno consiga observar os fenômenos sobre um olhar científico. Na experiência "Campo magnético de um solenóide", na página 290, por exemplo, é realizada a investigação do campo magnético ao redor de um solenóide ligado a um par de pilhas. Uma das questões faz a seguinte indagação: “ $A$ nova polaridade está de acordo coma determinação teórica? Comprove utilizando a regra da mão direita". As experiências fazem então o aluno observar que a teoria pode ser aplicada e observada em experiências simples. 


\section{Distribuição dos conteúdos em relação aos critérios de análise}

A seguir é apresentada uma tabela que mostra a distribuição dos conteúdos do livro em relação a alguns critérios escolhidos para análise.

Tabela 4. Distribuição dos conteúdos do livro em relação aos critérios escolhidos para análise para o livro Curso de Física

\begin{tabular}{|l|c|c|}
\hline & $N^{\circ}$ de páginas & \% em relação ao total de páginas \\
\hline Introdução e Índice & 5 & 1,0 \\
\hline Texto teórico & 90 & 19,2 \\
\hline Exercícios & 282 & 60,0 \\
\hline História da Física & 23 & 4,9 \\
\hline Cotidiano & 37 & 7,9 \\
\hline Experiências & 8 & 1,7 \\
\hline Resposta dos exercícios & 14 & 2,9 \\
\hline Tabela e Anexos & 11 & 2,4 \\
\hline Total & 470 & 100,0 \\
\hline
\end{tabular}

${ }^{184}$ Nesse livro a numeração das páginas começa depois da introdução geral, localizada nas primeiras páginas, e do índice. Sendo assim, são contabilizadas apenas as páginas referentes a introdução de cada "parte" (cada parte constitui um conjunto de capítulos). O índice remissivo, localizado no fim do livro, foi contabilizado em "Tabelas e Anexos". 


\section{Conclusões sobre o livro:}

Francisco Ramalho Junior, Nicolau Gilberto Ferraro e Paulo Antônio Toledo Soares são autores que possuem um trabalho docente muito intenso em cursos prévestibulares. Dos três autores, apenas Ferraro possui uma formação voltada para as questões da educação, pois é licenciado em Física pelo Instituto de Física da Universidade de São Paulo. Essas características fazem com que esse grupo de autores esteja preocupado com as questões referentes ao ensino proposto nos cursos prévestibulares. A Editora Moderna, por sua vez, é uma editora de grande porte, que faz parte do Grupo Santilla, que possui uma estrutura e atuação internacional e privada.

O resultado da combinação desses autores com essa editora é um livro que fundamentalmente apresenta uma física baseada na realização de exercícios para preparação para os exames vestibulares. O terceiro volume do "Os fundamentos da Física” tem em sua composição $60 \%$ de páginas dedicadas a exercícios de física. E, as diferentes seções que agrupam determinados exercícios, direcionam o estudante a conseguir resolver os últimos exercícios do capítulo, os testes de vestibular.

Os exercícios propostos nesses livros, além de serem numerosos, são concebidos de tal forma que não promovem o debate entre os alunos e entre o professor e o aluno. A grande maioria dos problemas exige a aplicação matemática de fórmulas físicas em situações abstratas, distantes da realidade do estudante. E, quase todas as respostas dos problemas são numéricas e absolutas, não permitindo assim a discussão.

Os textos voltados à história da física e ao cotidiano não contribuem muito para uma formação crítica, já que são textos superficiais, e que não relacionam o estudante com o conhecimento estudado. Os textos de história da física, em sua maioria, trazem os fatos históricos que representam as descobertas e invenções de forma desconexa, não mostrando ou mostrando superficialmente os debates dos cientistas. Os textos de cotidiano apresentam o funcionamento de certos aparelhos elétricos e explicação de fenômenos elétricos observáveis no dia a dia, mas os autores não colocam nenhuma questão e não promovem nenhuma atividade relacionada ao texto apresentado. A única interação que o estudante tem com a parte do cotidiano é a própria leitura do texto. E, tanto a parte da história da física quanto a destinada ao cotidiano, estão separadas do texto central, em seções particulares. Ou seja, não existe uma integração entre o texto teórico, que é voltado para a compreensão de fórmulas para posterior aplicação em exercícios, e as seções de história e cotidiano. 
As experiências, que também são colocadas em seções separadas do texto teórico, reforçam a teoria ao comprovar as leis e conceitos da física. Nessa parte os autores não relacionam as experiências com as atividades cotidianas dos alunos ou com o desenvolvimento histórico da física. As experiências, tanto em seu texto quanto nas perguntas realizadas, passam a impressão de que são colocadas no livro para que o aluno se convença de que todas a teoria realmente é algo verdadeiro.

Unindo essa perspectiva das experiências e o formato dos exercícios, o estudante pode acabar entendendo a ciência como algo que deve ser aceito, pois é verdadeiro. Essa dogmatização pode acabar atingindo a relação entre os alunos e entre professor e aluno, pois o livro ao não propor a discussão entre os colegas e ao indicar a aprendizagem como sendo a repetição do conhecimento descrito no livro pode culminar em um estudante que tenha uma postura passiva e de obediência. Isso fica claro também pela estrutura e proposta do livro que não incorpora os anseios dos professores e dos alunos. Todo o texto foi concebido pelos autores e não existe, em nenhum momento, a possibilidade da contribuição do professor e do aluno na construção do conhecimento.

De forma geral, o livro "Os fundamentos da Fisica 3" não apresenta textos voltados para as questões sociais, políticas, econômicas e sociais. O conteúdo do livro não contempla as questões atuais e não propicia uma investigação do estudante sobre esses assuntos. $\mathrm{O}$ conhecimento transmitido em seu texto é bem direcionado à resolução de exercícios e, por isso, pode acabar formando um estudante que tem como sua principal preocupação o ingresso no ensino superior, deixando assim de lado as questões fundamentais de nossa sociedade. O formato do livro também induz a formação de alunos passivos e obedientes, pois não promove o debate e participação do discente e do professor na construção do conhecimento.

Reunindo todas as informações e observações realizadas nos critérios de análise, pode-se comentar que está inferido nesse livro um currículo que, em sua ideologia, transmite valores e significados muito distantes dos PCN. A partir das análises apresentadas é possível dizer que o livro contém apenas a identificação, análise e aplicação de conhecimentos sobre valores de variáveis, representados em gráficos, diagramas ou expressões algébricas, realizando previsão de tendências, extrapolações e interpolações, e interpretações. Essa característica, aliás, é a que está mais presente devido ao excessivo número de exercícios proposto pelos autores. Além disso, os autores também tratam, nos textos dedicados ao cotidiano, da aplicação das tecnologias 
associadas às Ciências Naturais na escola, no trabalho e em outros contextos relevantes para sua vida. Em compensação, o livro não contempla:

- A compreensão das ciências como construções humanas, entendendo como elas se desenvolvem por acumulação, continuidade ou ruptura de paradigmas, relacionando o desenvolvimento científico com a transformação da sociedade, entender e aplicar métodos e procedimentos próprios das Ciências Naturais, pois nos textos do livro a historia da ciência não apresenta a ruptura de paradigmas e as variáveis sociais envolvidas no desenvolvimento científico ;

- A identificação de variáveis relevantes e selecionar os procedimentos necessários para produção, análise e interpretação dos resultados de processos ou experimentos científicos ou tecnológicos, pois os exercícios tratam apenas de problemas abstratos, as experiências não tratam de questões tecnológicas e cientificas e os textos do cotidiano apenas explicação o funcionamento dos aparelhos e fenômenos elétricos;

- A apropriação dos conhecimentos da Física, da Química e da Biologia, e aplicar esses conhecimentos para explicar o funcionamento do mundo natural, planejar, executar e avaliar ações de intervenção na realidade natural, já que pouco é dito sobre as outras áreas do saber e não realizado em nenhum momento o debate sobre as ações de intervenção do homem na natureza;

- A compreensão o caráter aleatório e não-determinístico dos fenômenos naturais e sociais e utilizar instrumentos adequados para medidas, determinação de amostras e cálculo de probabilidades, em decorrência da abordagem determinística e distante da realidade social;

- A análise qualitativa de dados quantitativos, representados gráfica ou algebricamente, relacionados a contextos socioeconômicos, científicos ou cotidianos; identificar, representar e utilizar o conhecimento geométrico para aperfeiçoamento da leitura, da compreensão e da ação sobre a realidade, pois os autores não tratam de questões sociais no texto teórico, nos exercícios, nas experiências e nos textos direcionados ao cotidiano e a história da ciência; 
- O entendimento da relação entre o desenvolvimento das Ciências Naturais e o desenvolvimento tecnológico, e associar as diferentes tecnologias aos problemas que se propuseram e propõem solucionar. As partes do cotidiano tangem essa questão, mas não chagam a discutir diretamente o desenvolvimento tecnológico;

- O entendimento do impacto das tecnologias associadas às Ciências Naturais na sua vida pessoal, nos processos de produção, no desenvolvimento do conhecimento e na vida social, pois o livro não aborda questões sociais;

- compreensão dos conceitos, procedimentos e estratégias matemáticas, e aplicá-las a situações diversas no contexto das ciências, da tecnologia e das atividades cotidianas, já que os a aplicação de procedimentos e estratégias matemáticas ocorrem mais nos exercícios que, por sua vez, tratam de situações abstratas, distantes do contexto das ciências, da tecnologia e das atividades cotidianas;

Ou seja, dos três setores de competência descritos nos PCN mais, o livro "Os fundamentos da Física 3" desenvolve muito mais a Representação e Comunicação do que a Investigação e Compreensão e a Contextualização Sociocultural, pois com seus exercícios faz com que o estudante saiba ler, articular e interpretar símbolos e códigos em diferentes linguagens e representando-os em sentenças, equações, gráficos e tabelas. Porém, em relação à Representação e Comunicação, o livro não promove a elaboração de comunicações orais, escritas, análise e argumentações críticas em relação a temas de cidadania e tecnologia, pois os exercícios são desenvolvidos em situações abstratas e as seções do cotidiano exigem apenas a leitura, já que não são propostos exercícios e atividades. A Investigação e Compreensão pouco é desenvolvido nas atividades já que a ação do aluno é a de seguir e repetir o que está descrito no texto teórico. Existe pouco espaço elaboração de hipóteses, interpretação e proposição de modelos para entender situações reais que envolvem fenômenos, sistemas naturais e tecnológicos. Por fim, como os autores não colocam em seus textos as questões sociais, a competência de Contextualização Sociocultural não é contemplada.

Além de ter uma tendência educacional distante da proposta dos PCN, o livro “Os Fundamentos da Física 3" também não apresenta propostas semelhantes com as descritas no ENEM. No caso, em relação as competências analisadas pelo ENEM, o livro "Os Fundamentos da Física 3" trabalha com o domínio da norma culta da língua 
portuguesa e faz uso das linguagens matemática e científica em seus exercícios, mas não trata em seus textos da linguagem artística; não tem em seus textos o conhecimento necessário para a construção e aplicação das várias áreas do saber para compreender os processos histórico-geográficos, da produção tecnológica e das manifestações artísticas, pois pouco aborda as questões sociais que envolvem o conhecimento científico; pouco ajuda na seleção, organização e interpretação de dados e informações para enfretamentos de situações-problemas, pois os exercícios são aplicados em situações abstratas e a resolução de problemas trata da simples repetição de problemas apresentados no texto teórico; relaciona em seus textos do cotidiano informações que proporcionam o conhecimento de situações concretas, mas, ao não interligá-los às questões sociais, não contribui para uma formação que promova a construção de argumentações consistentes para o debate; e não elabora propostas de intervenção solidária na realidade, já que os textos não falam de questões sociais e o formato de interação entre alunos e aluno e professor proposto, nas atividades, exercícios e texto teórico, incitam a ação individualizada.

Logo, os autores do livro "Os Fundamentos da Física 3" buscam um ensino voltado para os exames vestibulares e não para as propostas dos PCN e do ENEM. Essa tendência educacional, que atende ao mercado de livros e que vai na direção do adestramento de alunos a serviço de seu interesse em obter o diploma do Ensino Superior como credenciamento para o mercado de trabalho, alimenta os interesses conservadores, ou seja, não subsidia qualquer atitude crítica. O livro, ao não propor atividades emancipatórias, ao não construir o conhecimento levando em consideração os anseios autônomos dos professores e alunos, impõe um conhecimento rígido e inquestionável. Além disso, também trata a ciência como algo verdadeiro, sem modificação, sem revolução. Tudo isso reforça ao estudante que ele deve apenas seguir o que é imposto, sem questionar. 


\section{Conclusões}

Como descrito na introdução, o objetivo dessa dissertação era desenvolver uma análise do currículo que se pode inferir de três conjuntos de livros didáticos do Ensino Médio que tratam de eletromagnetismo. Inicialmente, para essa análise, foi realizada uma investigação sobre os pesquisadores de currículo. Entre os vários autores, discutidos no capítulo 3, foi escolhida a teoria de currículo de APPLE como referencial teórico para a análise dos livros didáticos. Além desse autor, outros incorporam a base teórica desse trabalho, entre os quais o educador FREIRE, que elucidou muitas questões sobre educação.

Tendo APPLE como referencial teórico, a análise teve alguns pressupostos que guiaram a reflexão e observação dos objetos de estudo. Primeiramente, a partir das idéias de APPLE, o currículo foi observado como algo que não consiste em uma simples montagem neutra de conhecimentos, mas sim uma seleção feita por alguém, quer possui interesses e que define o que é conhecimento legítimo. Essa seleção acontece no conflito que envolve questões culturais, políticas e econômicas de uma determinada sociedade. Sendo assim, o currículo pode ser um meio de controle de um determinado grupo sobre todo o povo. Como discutido anteriormente, YOUNG diz que as pessoas que estão em posição de poder tentam determinar o que deve ser considerado saber na sociedade e como e para quem esse conhecimento vai estar disponível.

Logo, a análise dos livros, tendo esse panorama, levou em consideração a relação entre ideologia e currículo apresentada por APPLE. Nessa relação, os alunos, através das atividades educacionais, passam pelos modos de incorporação, resultando no estabelecimento de uma cultura dominante efetiva que possui valores e significados que interessam para um determinado grupo. Tal ideologia é difícil de se identificar, como diz FREIRE, já que se trata de algo de difícil percepção, tornando possível à aceitação dócil de certos valores. Dessa forma, o currículo é muito mais do que um rol de conhecimentos colocados de forma ordenada, ele possui uma série de valores e significados que consistem a ideologia de um determinado grupo. E todo esse sistema se desenvolve em uma sociedade, fazendo com que a educação esteja envolvida com economia, política, cultura, entre outros. Ou seja, para analisar o currículo que se pode inferir nos livros didáticos, é necessário compreender o currículo dentro das diferentes variáveis sociais. No caso, APPLE aborda, como variáveis sociais que interagem com o 
currículo, a existência de um currículo nacional e uma avaliação nacional, o papel reprodutor da escola, a determinação do que é considerado conhecimento legítimo, e o comércio de livros. No Brasil contemporâneo essas variáveis se refletem, basicamente, em três personagens da educação, que são os PCN, o ENEM e os exames vestibulares, que foram discutidos no capítulo 7. E, a situação atual, bem como a ideologia passada por esses personagens, é resultado de uma história que começou em 1549, na Bahia, com a fundação da primeira escola do país, e que passou por uma série de momentos marcantes e atingiu, no século $\mathrm{XX}$, novas características, com o desenvolvimento industrial, e teve, nas ultimas décadas, projetos educacionais importantes, como o PSSC, PEF, PBEF e FAI. Essa evolução e as dificuldades enfrentadas pelos educadores, como descritas por ZANETIC, explicam a situação atual e serviram de pano de fundo para a análise dos livros didáticos contemporâneos.

Tendo essa base teórica e a compreensão da situação atual do país, foram realizadas algumas questões que guiaram as análises e conclusões de cada livro didático. Essas questões tentavam identificar quem definiu o currículo inferido nos livros didáticos, quais eram os objetivos das pessoas que definiram o currículo no livro didático, se os objetivos e anseios dos alunos e professores foram contemplados nos livros didáticos, se existe abertura para a participação dos professores e alunos na construção do conhecimento, se o conteúdo e a forma dos livros didáticos possuem alguma tendência ideológica e se o aprendizado proposto nos livros contemporâneos analisados proporcionam uma formação crítica, relacionando a física e a sociedade, em relação à política, cultura, economia e outros. Com essas questões em mente, foram elaborados alguns critérios que, a partir da visão de currículo apresentada, permitiu uma análise de cada livro.

A partir da análise dos livros é possível dizer que eles possuem currículos bem diferentes entre si. No livro "Curso de Fisica", de Antonio Máximo e Beatriz Alvarenga, o currículo foi definido a partir de uma pesquisa que os autores realizaram com professores do Ensino Médio. Além disso, a formação desses autores contribuiu para a concepção de um livro que se aproxima, em muitos momentos, das idéias dos PCN e do ENEM. Já as "Leituras de Física: Eletromagnetismo", do GREF, representam o que é dito por SMITH, O’DAY e COHEN, no sentido que foi realizado um trabalho cooperativo para a construção do livro didático, constituindo assim algo que ultrapassa o simples desenvolvimento técnico de materiais educacionais. Já o livro "Os Fundamentos da Física", de Francisco Ramalho Junior, Nicolau Gilberto Ferraro e 
Paulo Antonio de Toledo e Soares, não apresenta uma construção conjunta com outros professores ou pesquisa com os docentes, representando como resultado um livro que serve aos exames vestibulares, presentes no cotidiano dos autores que são professores de cursos pré-vestibulares. Assim, as "Leituras de Física: Eletromagnetismo" tratam dos objetivos daqueles estarão de fato trabalhando diretamente com educação, enquanto que o "Os Fundamentos da Física" retrata o interesse pelo ingresso no Ensino Superior e suas consequiências em nossa sociedade, tratadas no capítulo 7. A participação na construção do conhecimento fez com que as apostilas do GREF tivessem uma estrutura bem diferente dos outros livros. Todo o currículo, realmente, está sobre o eixo do cotidiano, desde sua estruturação de temas, até a abordagem e aplicação dos conhecimentos. Essa aproximação do aluno com as situações do dia a dia o motiva para o estudo e traz a cultura do estudante para dentro de sala de aula, ao invés de impor elementos de estudos abstratos e desconexos que transmitem uma ideologia de passividade e obediência. Aliás, a construção do conhecimento fica bem visível nos exercícios propostos nos livros. Nas apostilas do GREF os exercícios trabalham com variáveis e situações que o estudante encontra em sua própria casa. E, além disso, os exercícios, em sua maioria, permitem diferentes respostas e caminhos, dando liberdade ao estudante. Já no "Curso de Física” e no " Os Fundamentos de Física”, os exercícios são fechados, são aplicados em casos abstratos, e não incorporam dados e situações cotidianas. Com isso, a cultura do aluno é excluída e o conhecimento se dá de fora para dentro do estudante. E, ao ter respostas absolutas, o estudante tem que seguir o caminho descrito, pois, caso contrário, estará cometendo um erro. Logo, é imposto um conhecimento externo ao estudante que depois é cobrado em exercícios. No caso do "Os Fundamentos da Física” isso fica mais presente, pois os muitos exercícios seguem uma ordem que culminam nos testes de vestibular. Ou seja, para o aluno e para o professor fica a imagem de que aprender é conseguir resolver os testes de vestibular. Eles, dessa forma, assegurariam a compreensão de certo conhecimento, indicando assim uma tendência que vai contra os PCN e o ENEM.

O livro "Curso de Física", dos autores Antônio Máximo e Beatriz Alvarenga, apesar de ter exercícios fechados, possui outras características que o levam a tendências educacionais propostas nos PCN e ENEM. Nesse livro os textos de Historia da Física apresentam os debates dos cientistas, a evolução dos conceitos, mesmo que em poucas páginas. Isso possibilita ao aluno um olhar da ciência próximo ao de KUHN, já que se percebe superficialmente as revoluções científicas na física. Além disso, os textos do 
cotidiano contribuem para uma ligação entre a física e o dia a dia do aluno. Por sua vez, o "Os Fundamentos de Física", traz textos de Historia de Física que não mostram os debates científicos e coloca as descobertas e invenções de forma desconexa e os textos de cotidiano não incitam atividades e participação do estudante. Finalmente, as "Leituras de Física: Eletromagnetismo" quase não tem História da Física, mas todo o seu texto é voltado para o cotidiano.

Apesar de todas essas diferenças entre os livros é possível perceber uma coisa comum entre eles, às questões sociais que desenvolveriam a competência de Contextualização Sociocultural, estão ausentes nos textos. Não são abordadas as relações das ciências e seu papel na vida humana, no impacto social e na utilização de seus conhecimentos para o exercício da cidadania. A intervenção solidária na realidade também não é contemplada. Isso faz com que o estudante não veja as relações entre a física e a sociedade e como os conhecimentos da escola podem e devem ser aplicados de forma crítica nas ações do dia a dia. Apenas com um aprendizado crítico é possível enfrentar e se libertar da ideologia imposta por certos grupos que querem o controle da sociedade. A emancipação, assim, só pode ser conseguida com a educação sendo uma frente de luta contra imposições e contingências.

De forma geral, as apostilas do GREF representam o que APPLE acredita ser uma boa educação, já que constitui a construção conjunta do conhecimento pelos integrantes da escola. Se isso fosse realizado em ampla escala, democraticamente, o resultado seria o esperado por APPLE. Para complementar, textos de história da física contribuiriam para o estudante ver a ciência como algo que acontece através de revoluções, propagando assim a idéia de que é preciso lutar para mudar as coisas. O "Curso de Física" apresenta tendências ideológicas dos PCN e ENEM, mas ainda possui trações dos exames vestibulares e de uma educação que impõe o conhecimento e não aceita a participação da cultura do aluno. Os exercícios deviam ser mais abertos, possibilitando a inserção de elementos da vida do discente. E, a estrutura, ainda que apresentando seções com texto de cotidiano e história da física, não se integra essas seções e o texto teórico. O "Os Fundamentos da Física" representa o ensino para os exames vestibulares. Seus exercícios e textos podem fazer o estudante ter atitudes passivas, de aceitação de regras e de conhecimentos distantes de sua realidade, tendo em vista o objetivo de ter sucesso nos exames para o Ensino Superior.

Logo, por essa análise, é possível ver que existem diferenças e semelhanças entre os livros analisados. Com a proposta dos PCN e do ENEM e possuindo a intenção 
de propiciar uma formação crítica é possível perceber que algumas coisas precisam ser mudadas. Esse trabalho não pretendeu investigar detalhadamente cada critério analisado e também não teve a pretensão de indicar como deve ser o livro ideal. Mas por meio da análise realizada notou-se que as variáveis sociais que cercam a educação interferem profundamente nas atividades escolares. Uma mudança não envolveria apenas a produção de um novo livro didático, mas sim uma ação que envolveria toda a sociedade, indo contra os interesses de determinados grupos que querem o controle da sociedade. Só com a construção democrática, levando em consideração os anseios de professores, educadores, alunos, entre outros, será possível ter uma educação que propicie liberdade ao estudante e uma postura questionadora frente as questões sociais.

Não é demais também lembrar que essa dissertação não tratou simplesmente de fazer uma análise dos conceitos de eletromagnetismo apresentados em diferentes livros didáticos. Nesse trabalho foram mostrados e discutidos aspectos científicos, metodológicos e ideológicos da noção implícita de currículos presentes nos livros didáticos. 


\section{Conjecturas sobre o futuro dos recursos didáticos}

Há pouco, eu comemorei meu aniversário com minha namorada. Demos umas voltas, almoçamos fora e, por fim, acabei comprando em uma loja de brinquedos um quebra-cabeça de 1.500 peças. Eu já tinha anteriormente montado outros quebracabeças, mas minha namorada nunca teve essa oportunidade e acabei adquirindo o brinquedo.

Em casa, após desfrutar um pouco mais da cidade de São Paulo, tiramos os vasos de flores de uma mesa antiga e grande e espalhamos todas as peças do quebracabeça. Inicialmente, fiquei preocupado ao ver todas as peças e o desafio que elas representavam. Ficamos olhando as peças e a imagem do Golfo de Salerno, no sul da Itália, estampado na caixa do brinquedo. Não sabíamos nem por onde começar.

Depois de algum tempo, pensamos em buscar e montar as peças que ficavam na borda. Com isso, seria fácil visualizar o espaço que o quebra-cabeça ocuparia na mesa e o local onde as peças do centro estariam posicionadas. Fizemos isso com sucesso. Deixamos então para montar as demais peças nos outros dias.

Ao longo da outra semana, enquanto montava os primeiros barcos do Golfo de Salerno, comecei a refletir sobre minha dissertação. Pensei, basicamente, em como poderia concluir o trabalho e como toda a leitura que fiz mudou profundamente alguns dos meus conceitos (ou pré-conceitos). Eu já tinha pensado nisso antes e estava quase certo que iria escrever sobre tecnologia e educação. Os avanços na tecnologia têm ocasionado muitas possibilidades para a educação. As novas ferramentas de comunicação propõem um novo paradigma onde o livro didático e os meios de informação, de forma mais geral, podem sofrer transformações. $\mathrm{O}$ advento da tecnologia não é abordado por APPLE (pelo menos nos textos que li) e acredito que pensar uma educação do futuro, que promova uma formação crítica, é também pensar na variável tecnologia da informação.

Mas, ao montar o quebra-cabeça, comecei a refletir sobre outro aspecto do conhecimento. A cada peça montada, eu ia conhecendo melhor o Golfo de Salerno. A imagem estampada na caixa me dava uma visão geral de uma localidade do sul da Itália, mas, cada peça, que retrata uma ampliação de um pequeno pedaço da imagem, continha uma série de informações que eram fundamentais para sua localização entre as outras peças. Eu conseguia ver as crianças vendo o mar, os detalhes das construções antigas 
nas rochas e os barcos, que eram muito coloridos por sinal. A imagem da caixa se mostrou um conjunto de milhares de informações que misturavam cores, formas e significados. De certa forma cada fragmento contava por si só algo da paisagem toda, de forma metaforicamente fractal.

A minha dissertação, nesse sentido, também é um quebra-cabeça. As citações e os dados configuravam as peças. A dissertação, que é a reunião dessas peças, significava o quebra-cabeça. A minha ação estava então em juntar essas peças de tal forma a formar um todo estruturado. Essa relação do quebra-cabeça com a dissertação de mestrado ficou vagando na minha mente por vários dias. Algumas vezes, essa visão era confortante, mas em outras trazia certas coerências e incoerências também fractais.

Ao terminar toda parte da praia, mar e barcos, eu percebi que a dissertação é realmente um quebra-cabeça, mas sua proposta é diferente. Em um quebra-cabeça, todas as peças estão contidas na caixa. Não existem peças em outros lugares e também não é possível criar novas peças. O resultado também é conhecido anteriormente. O objetivo do brinquedo é conseguir montar a imagem do Golfo de Salerno. Diferente disso, escrever uma dissertação se baseia em reunir peças de vários quebra-cabeças diferentes. Cada livro consultado, no caso, é um quebra-cabeça e minha ação foi a de escolher peças de diferentes livros e reuni-las de uma forma muito pessoal. Dessa forma, o resultado final não é uma imagem conhecida anteriormente. Aliás, a imagem final pode ser qualquer coisa.

O conhecimento que adquiri com a dissertação então significa o estudo de diversas peças e suas conexões. E esse estudo se apresenta não só na informação contida em cada peça, mas em sua busca e relação com outras peças. A busca remete ao fato de que os meus valores e minha ideologia estavam presentes na seleção das peças. $\mathrm{Na}$ busca, eu escolhi e rejeitei. Essas ações, que amadureceram meu olhar para informação, da mesma que amadureci meu conhecimento de tonalidades de cor ao montar o céu do Golfo de Salerno, despertaram habilidades que estavam um pouco adormecidas em mim. A iniciativa de ir atrás das peças, de consultar colegas sobre as peças que eles estavam utilizando e de selecionar quais peças fariam parte da minha dissertação fizeram bastante diferença na minha formação de mestre. A relação entre as peças também foi importante e mostrou ser uma característica bastante interessante. No quebra-cabeça, as ondulações e pontas das peças confirmam ou não o encaixe com outras peças. Com um simples ajuste mecânico é possível constatar se uma peça está no lugar certo ou não. Na dissertação, o encaixe é desenvolvido pelo mestrando, onde as 
relações se transformam e o encaixe entre as peças é elaborado. O ajuste mecânico passa a ser, na dissertação, um processo orgânico e dinâmico, até a sua conclusão. Ainda hoje, antes de encerrar meu trabalho, eu modifico textos escritos há dois anos. $\mathrm{O}$ quebra-cabeça está em constante movimento.

Todas essas idéias relacionam o conteúdo e a realização do meu trabalho. Quando estava montando o céu, notei, com felicidade, que não existia diferença entre meu texto e minha ação ao fazer o texto. Muito do que escrevi está em minha prática ao escrever. E chegando ao fim dessa dissertação, vi que o resultado é um trabalho de dissertação de ensino de física, mas, mais do que isso, também são minhas idéias representadas em texto. A imagem formada funde entre um texto acadêmico e minha própria pessoa. Isso ficou mais claro quando eu passei minha dissertação para um colega ler. Ele me disse que encontrou partes que denunciam a autoria. Ou seja, qualquer pessoa que me conhece, ao ler a dissertação, vai encontrar um pouco de mim nas linhas redigidas.

Esse aprendizado, que proporcionou momentos muito interessantes na minha vida, deveria ser experimentado por todos, em todos os níveis. O ensino, ao invés de ser um quebra-cabeça tradicional, com uma imagem pré-definida e com peças já selecionadas, deveria ser um processo orgânico e dinâmico que dependesse intrinsecamente da participação ativa do estudante. Dessa forma, o conhecimento deveria ser montado pelo aluno e o resultado de anos de estudo deveria configurar sua própria imagem, com seus valores, significados e ideologia. Durante esse processo, o estudante vai defrontar, na busca, seleção, e relação entre as peças, questões que envolvem a sociedade, pois essa metodologia envolve valores, significados e ideologia. O professor nesse contexto tem que ser o mediador do conhecimento. Ele deve ajudar o aluno nesse processo sem impor sua ideologia e trazendo conhecimentos que gerem o conflito e a discussão. O professor então não vai ser o detentor do conhecimento, pois esse não está predefinido. O professor deve ajudar o estudante a buscar seu próprio caminho entre as peças do seu próprio quebra-cabeça.

O livro didático, hoje, constitui uma peça ou uma coletânea de peças. Da mesma forma que o brinquedo de quebra-cabeça, o livro didático contemporâneo tem uma imagem predefinida e peças, que são os capítulos e as seções do livro. Essas peças são montadas linearmente, tem um número de peças definido (que limita o conhecimento do aluno) e suas peças já foram escolhidas e definidas. Assim, cabe ao discente apenas seguir, peça a peça, o "desenvolvimento" do conhecimento escolar. O professor, no 
caso, ajuda o aluno a seguir essa linearidade e a montar, sem questionar, peça a peça, formando assim um quebra-cabeça que não foi definido pelo aluno. A imagem final obtida é algo completamente diferente do aluno. É a imagem que certos grupos querem que os estudantes tenham. É uma imagem que propicia o controle e produção de “cidadãos” passivos, obedientes e que aceitam todo tipo de situação imposta.

A questão, que é levantada por APPLE, é que existem mecanismos que garantem a formação de uma imagem predeterminada do aluno. No Brasil, os exames vestibulares cobram um quebra-cabeça fechado e limitador que influencia os alunos, professores e escolas. Essa influência acaba por não dar liberdade de escolha e construção do conhecimento pelo aluno. E as editoras, para seguirem a tendência do mercado para obter o máximo de lucro, acabam por produzir livros didáticos que seguem o quebra-cabeça padrão exigido nos exames vestibulares. Esse círculo vicioso traz a impressão de que nada pode ser feito, que é impossível uma mudança.

Na pós-graduação, é exigido um outro tipo de desenvolvimento educacional. Aliás, é esperado que o mestrando traga um quebra-cabeça novo, diferente dos anteriores. É interessante, ao ler várias dissertações, notar as diferentes combinações realizadas com peças iguais. Cada mestrando monta sua própria imagem em seu texto. Seria muito bom se os exames vestibulares cobrassem dos interessados em ingressar no Ensino Superior um produto que significasse o próprio candidato, mostrando sua trajetória, suas escolhas, sua ideologia.

Toda essa idéia construída que relaciona o quebra-cabeça, dissertação e ensino também se relaciona com a tecnologia da informação que descrevi brevemente no começo desse texto. Com a Internet e o acesso generalizado a computadores, a interação entre as pessoas e a informação mudou. Antigamente, para se obter um conhecimento específico e ausente do ambiente cotidiano (eletromagnetismo, por exemplo), era preciso ir a uma biblioteca. Algumas escolas tinham grandes bibliotecas e algumas cidades tinham centros de cultura e informação, mas esses espaços, por alguma razão, não se relacionavam diretamente com a vida das pessoas. Apenas as pessoas que realmente gostavam de ler visitavam esses "templos do conhecimento". Por sua vez, a televisão e jornal, trazem informações cotidianas (notícia sobre o impacto econômico e ambiental de uma hidrelétrica, por exemplo) e conseguem chegar mais próximos das pessoas, estabelecendo uma interação maior e mais rápida. Nesse contexto, o quebracabeça fica difícil de ser montado, pois a busca demanda um certo gasto de energia e tempo. A seleção e relação entre as peças também é uma tarefa árdua, pois o sistema de 
busca não contribui para a seleção de peças. Como resultado, poucas relações eram estabelecidas. Com as novas tecnologias de informação, a informação ficou muito mais acessível e as diferentes ferramentas de busca contribuem muito para seleção de peças. Com uma grande quantidade de peças selecionas, o estudante consegue fazer mais relações. Além disso, as novas tecnologias da informação apresentam tanto informações específicas como cotidianas.

Toda essa nova tecnologia impulsiona e promove uma nova interação com a informação. Com essas novas ferramentas, um professor tem a possibilidade de desenvolver uma aula onde os estudantes constroem seu próprio conhecimento ao ir atrás de referencias, noticias, exercícios, entrevistas sobre questões polêmicas, entre outras coisas. Nessa visão, o quebra-cabeça não tem bordas e, por isso, não tem limites. E também não tem formato, não precisa um retângulo, pode ser um círculo, uma estrela, ou algo em terceira dimensão, como uma escultura.

A liberdade gerada nesse processo é muito grande. Porém, a quantidade de informação existente também é muito grande. O problema atual da tecnologia da informação se concentra na seleção de peças. Nos sites de busca aparecem uma infinidade de possibilidades de informação, da mesma forma que existia muitos meios e perspectivas de eu tratar da minha dissertação. O professor pode ser um orientador, mas existe a necessidade de utilizar cada vez mais ferramentas que auxiliam na construção do conhecimento. Essa tendência promove a liberdade e impede a imposição de uma ideologia na escola, pois, nesse processo, os valores e significados são trabalhados pelos alunos.

A tecnologia a cada ano avança no sentido de facilitar o acesso a informação. Hoje, em uma mídia de DVD, é possível armazenar milhares de livros. Com os computadores de mão, PALMTOPS, as pessoas podem ter acesso a internet e armazenar textos, imagens, músicas e vídeos. Em breve, um pequeno "chip" vai acessar todos os livros escritos, todas as músicas compostas e todos os vídeos produzidos. Isso vai alterar profundamente os mercados literário, musical e de vídeo. Acredito que o livro didático, nessa onda, não vai ser mais constituído de papel. O aluno, no futuro, vai ter ferramentas mais acessíveis e amplas de comunicação.

A linguagem incorporada nas novas tecnologias da informação também segue um novo padrão. A busca e leitura de um texto não segue uma linearidade. Na Internet, um texto pode ter links (conexão) no meio do seu corpo. Esses links levam o leitor para 
outro texto correlato, sendo que nesse novo texto também tem outros links. Ou seja, a leitura segue um padrão não linear, dando liberdade para o leitor escolher sua trajetória de leitura. Às vezes, em uma única página de Internet, é possível ver três campos que separam três textos diferentes, mas correlatos. Essa estrutura de leitura, identificada como hipertexto, promove a possibilidade de escolha. Alguns livros impressos hoje seguem essa tendência. Algumas enciclopédias possuem hoje seu conteúdo disposto no centro das paginas e nas bordas pequenos textos que aprofundam certas partes do texto principal. Esses pequenos textos, que se parecem com notas de rodapés com textos explicativos, são ligados graficamente com uma linha ou imagem ao texto principal. Esse formato, que ramifica o texto, permite um maior conteúdo, mas ainda esta longe de ser uma ferramenta de informação como a Internet.

Refletindo sobre tudo isso e tendo terminado o quebra-cabeça, entendo que o livro didático deveria promover a liberdade e formação critica dos alunos. A construção do conhecimento pelos alunos é fundamental. Acredito que o livro didático deveria, a curto prazo, ser incrivelmente dividido, constituindo "fascículos" didáticos. Cada "fascículo" possuiria de 3 a 4 páginas e enfocaria uma faceta do conhecimento. No caso do eletromagnetismo, por exemplo, na abordagem de aparelhos que armazenam energia, o aluno deveria ter a sua disposição, por exemplo, 30 "fascículos" sobre o assunto. Poderíamos listar as seguintes abordagens:

1 - observação, listagem e medição de grandezas físicas de aparelhos que armazenam energia na casa do aluno;

2 - estrutura interna desses aparelhos;

3 - contexto histórico na qual foi criado o capacitor e o conceito de armazenamento de energia;

4 - questões relacionadas com o consumo de energia e a distribuição de energia do país;

5 - exercícios matemáticos;

6 - uma conexão entre química e física através da eletroquímica;

7 - entre outros.

E cada uma dessas abordagens teria outros "fascículos". Obviamente, não seria possível ver todos os "fascículos", mas o aluno escolheria aqueles que mais o interessam. Os "fascículos" seriam então algumas peças para seu quebra-cabeça. E essas 
peças seriam complementadas com outras peças, de textos paradidáticos, recortes de jornais, vídeos, entre outros. Mas para isso, os fascículos incitariam uma postura do aluno que apontasse para a procura de novos meios de comunicação. O "fascículo" deve propiciar, através de atividades propostas, a interação e discussão entre os alunos, resultando em uma busca por mais informações e conhecimento. No "fascículo" sobre contexto histórico na qual foi criado o capacitor e o conceito de armazenamento de energia, o estudante teria que relacionar as dificuldades e necessidades enfrentadas na época da criação do capacitor com as dificuldades e necessidades atuais. Nessa relação, que incorporaria noticias de jornal e outros, o aluno entenderia melhor as relações sociais que envolveram os cientistas no passado, além de passar a ter uma postura questionadora frente as questões sociais atuais. Para o debate, os alunos, em grupos, deveriam apresentar argumentações e fatos que relacionam ou não o passado e a época atual. Através da troca de idéias, o estudante reflete sobre o assunto, aprende e ensina com os colegas, e possui uma visão ideológica própria sobre o mundo. Nessa estrutura, cada aluno se desenvolve de uma forma diferente, pois no debate alguns buscaram argumentos técnicos, outros sociais e outros históricos. E a base de informação começaria na consulta não linear e não imposta dos diferentes "fascículos" existentes.

A longo prazo, esses "fascículos" estariam disponíveis pela internet ou por meios de informação mais acessíveis. Com as novas ferramentas de informação é possível existir uma infinidade de "fascículos". Seguindo essa linha, o Estado, através dos cursos de ensino das Universidades Públicas ou de concursos abertos a professores da rede pública, poderia fomentar a redação desses fascículos, com prêmios, ajuda de diagramação e distribuição. Assim, o coletivo dos professores comporiam uma base de informações para os estudantes. Os estudantes, por sua vez, contribuiriam com a exposição e apresentação do seu quebra-cabeça em sites na Internet, por exemplo.

Nessa proposta, os livros didáticos se fragmentariam em muitos "fascículos" e a trajetória de ensino do aluno seria composta pela escolha e composição desses "fascículos" ao longo de sua formação. Com isso, o aluno forma sua própria ideologia e não permite a imposição de valores e significados de certos grupos. A liberdade promovida renderia um cidadão mais questionador e crítico para a sociedade.

Ao fim dessa dissertação e do quebra-cabeça, sinto um pouco de esperança, talvez em idéias ainda ingênuas e questionáveis em suas aplicações, mas que norteiam uma possível mudança dentro de mim e na minha ação docente. Meu quebra-cabeça não está terminado e vai sempre estar em movimento e, apresentá-lo aqui expressa outra 
esperança, de que ele não seja só meu, mas que, de certa forma, seja também "fractalmente" universal. 


\section{Bibliografia}

Parâmetros Curriculares Nacionais: Ensino Médio / Ministério da Educação, Secretaria de Educação Média e Tecnológica. Brasília : MEC; SEMTEC, 2002.

Leituras de Física - Eletromagnetismo (5 apostilas). GREF / Grupo de Reelaboração do Ensino de Física. São Paulo:, junho de 1998.

, The Physics Teacher (Estados Unidos: American Association of Physics Teachers, vol. $37 \mathrm{n}^{\circ}$ 5. Maio, 1999.

PCN Mais Ensino Médio: Orientações Educacionais complementares aos

Parâmetros Curriculares Nacionais. - Ciências da Natureza, Matemática e suas Tecnologias. Secretaria de Educação Média e Tecnológica - Brasília : MEC ; SEMTEC, 2002.

ALMEIDA, Aires. Filosofia e ciências da natureza: alguns elementos históricos. Centro de Filosofia e Ciências Humanas / Universidade Federal de Santa Catarina. http://www.cfh.ufsc/ wfil/aires.htm. 10/09/05

ALMEIDA, João Baptista de Junior. A Evolução do Ensino de Física no Brasil. Revista de Ensino de Física. Vol 1 n ${ }^{\circ}$ 2. Outubro, 1979. Impresso na gráfica do Instituto de Física da USP.

ALVARENGA, Beatriz e Máximo, Antônio. Curso de Física, vol. 3, $5^{\circ}$ edição (1 impressão). São Paulo: Scipione, 2000

APPLE, Michael W. Educação e poder; trad. De Maria Cristina Monteiro - Ed. Artes Médicas, Por to Alegre, 1989

APPLE, Michael W. Trabalho docente e textos: economia política das relações de classe e de gênero na educação; trad. De Thomaz Tadeu da Silva, Tina Amado e Vera Maria Moreira. Ed. Artes Médicas, Porto Alegre, 1995 
APPLE, Michael. Política cultural e educação; trad. De Maria José do Amaral Ferreira. Ed Cortez, São Paulo, 2000

APPLE, Michael W. Ideologia e Currículo. Ed. Brasiliense, 1982.

APPLE, Michael W. Conhecimento oficial: a educação democrática numa era conservadora / trad. Maria Isabel Edelweiss Bujes. - Petrópolis, RJ : Vozes, 1997

BITTENCOURT, Diomar da Rocha Santos. Uma análise do projeto de Ensino de Física - Mecânica. Dissertação de Mestrado, IFUSP e Faculdade de Educação da USP.

DOMINGUES, José Luiz, Interesses humanos e paradigma escolar, Revista Brasileira de Estudos Pedagógicos, Brasília. V. 67, n. 156, p. 351-66, maio/ago

DOMINGUES, José Luiz e COSTA, Nilce Maria da Silva Campos. As concepções de currículo: uma revisão. A ser publicado.

EINSTEIN, Albert. Notas Autobiográficas. . Ed. Comemorativa / traduzida e anotada por Paul Arthur ; tradução de Aulyde Soares Rodrigues, - Rio de Janeiro: Nova Fronteira, 1982

FREIRE, Paulo. Pedagogia da Autonomia. Ed. Paz e Terra, 1996. $28^{\circ}$ Edição.

FREIRE, Paulo. Pedagogia do Oprimido. Rio de Janeiro, Ed. Paz e Terra, 2005. $41^{\circ}$ Edição.

GRUNDY, Shirley. Producto o práxis del curriculum. Madrid, Espanha: Ed. Morata. 1991. 277 p.

JÚNIOR, João Baptista Almeida. A evolução do ensino de Física no Brasil. Revista de Ensino de Física, vol. 1, n² 2, out/1979. 
KRASILCHIK, Myrian. O professor e o currículo das ciências. São Paulo: Ed. Universidade de São Paulo. 1987.

LARANJEIRAS, Cássio Costa. Redimensionando o ensino de física numa perspectiva histórica. São Paulo, 1994. Dissertação de Mestrado - Universidade de São Paulo / Instituto de Física

LEWY, Arieh, organizador. Avaliação de Currículo. São Paulo: Ed. Universidade de São Paulo. 1979. 313 p.

LOPES, José Leite. O desenvolvimento da ciência e os povos do terceiro mundo. Revista paz e Terra, ${ }^{\circ}$ 8, setembro/ 1968, pág. 99.

MACHADO, Nilson José. Cidadania e Educação - $4^{\circ}$ Ed. São Paulo: Escrituras Editora, 2002. - (Coleção Ensaios Transversais).

MENEZES, Luis Carlos de. A Ciência como Linguagem em O Currículo na Escola Média: Desafios e Perspectivas, Org. Luís Fábio Simões Pucci e Regina Cândida Ellero Gualtieri. Secretaria da Educação, Coordenadoria de Estudos e Normas Pedagógicas. São Paulo : SE/CENP; Brasília; MEC/SEMTEC/BID, 2004.

PACCA, Jesuína L. A. Análise do Desempenho de Alunos frente a Objetivos do Projeto de Ensino de Física. IFUSP e FEUSP, 1976

PACHECO, José Augusto. Currículo: Teoria e Práxis. São Paulo, Porto Editora. 1996.

PALMA, José Cardoso Filho. Sociedade, educação e Currículo Escolar em $O$ Currículo na Escola Média: Desafios e Perspectivas, Org. PUCCI, Luís Fábio Simões e GUALTIERI, Regina Cândida Ellero. Secretaria da Educação, Coordenadoria de Estudos e Normas Pedagógicas. - São Paulo : SE/CENP; Brasília; MEC/SEMTEC/BID, 2004.

PEREIRA, Jairo Alves. Uma reelaboração de conteúdo de física do segundo grau: a eletricidade como exemplo. São Paulo, 1995. Dissertação - Universidade de São Paulo. Instituto de Física. Orientador: Profa. Dra. Yassuko Hosoume. 
PESSOA, Osvaldo Jr. Filosofia \& Sociologia da Ciência: Uma Introdução. http:/www.cfh.ufsc.br/ wfil/sociociencia.htm 21/09/05.

RAMALHO, Francisco Junior, FERRARO, Nicolau Gilberto e SOARES, Paulo Antonio de Toledo. Os Fundamentos da Física, vol. 3, 8. ed. ver. e ampl. - São Paulo: Moderna, 2003.

SAAD, Fuad D. Análise do Projeto FAI - Uma proposta de um curso de Física Auto Instrutivo para o $2^{\circ}$ Grau, IFUSP e FEUSP, 1997.

SALÉM, Sonia. Estruturas conceituais no ensino de física: uma aplicação à eletrostática. São Paulo, 1986. Dissertação - Universidade de São Paulo. Instituto de Física. Orientador: Prof. Dr. Manoel R. Robilotta.

SILVA, Teresinha Maria Nelli. A construção do currículo na sala de aula: o professor pesquisador. São Paulo: Ed. Universidade de São Paulo. 1990.

VEIGA, Ilma Passos Alencastro (org.). Projeto Político-pedagógico da escola: Uma construção possível. Campinas (SP): Papirus, 1997

YOUNG, Michael. O Currículo do futuro: da "nova sociologia da educação" a uma teoria crítica do aprendizado. Campinas, SP: Papirus, 2000.

ZANETIC, João. Apostila da disciplina Propostas e Projetos de Ensino de Física. IFUSP, 2000. 